\title{
QUALIDADE DO TRANSPORTE PÚBLICO URBANO POR ÔNIBUS NA CIDADE DE JAÚ
}

\section{Enga Magaly Natália Pazzian Vasconcellos Romão}

Orientador: Prof. Antonio Clóvis Pinto Ferraz

\author{
Serviço de Pós-Gradução EESC/USP
}

EXEMPLAR REVISADO

Data de entrada no Serviço:./.3..././.I.../.,Q.2.

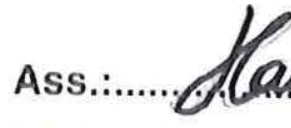

గise itaçân desenvolvida om programa de mestrado junto à Área de Pós-graduação em Transportes da Escola de Engenharia de São Carlos, da Universidade de São Paulo.

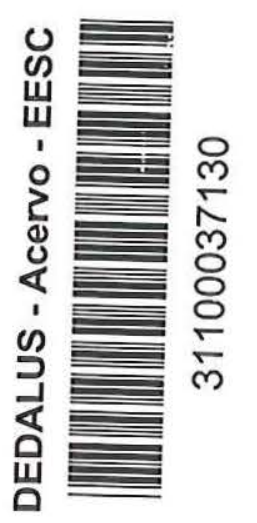

São Carlos 2002

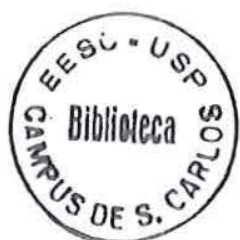


Candidata: Engenheira MAGALY NATALIA PAZZIAN VASCONCELLOS ROMÃO

Dissertação defendida e julgada em 25-09-2002 perante a Comissão Julgadora:

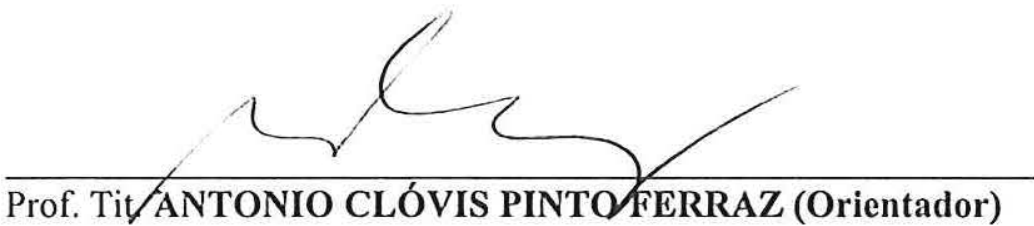

$11716 \cdot 1+11^{\circ}$

(Escola de Engenharia de São Carlos/USP)

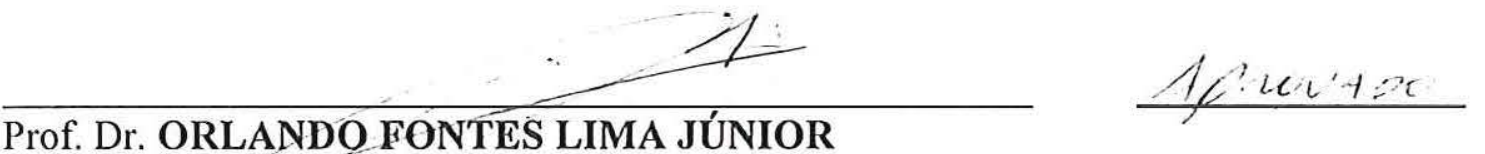

(Universidade Estadual de Campinas/UNICAMP)

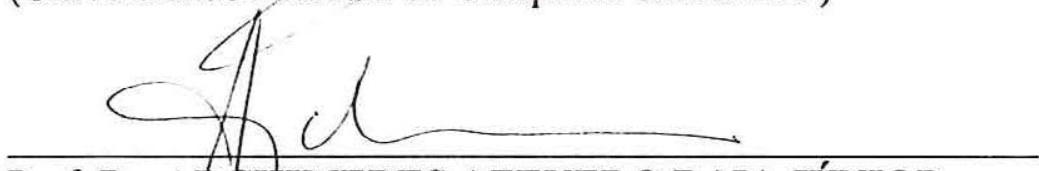

Afkolatis

Prof. Dr. ARCHIMEDES AZEVEDO RAIA JÚNIOR

(Universidade Federal de São Carlos/UFSCar)

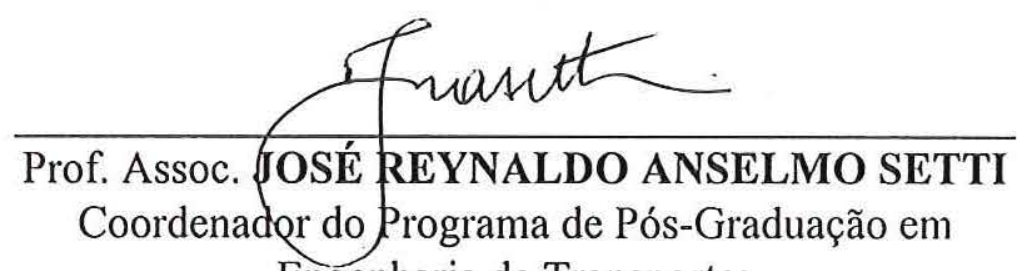

Engenharia de Transportes

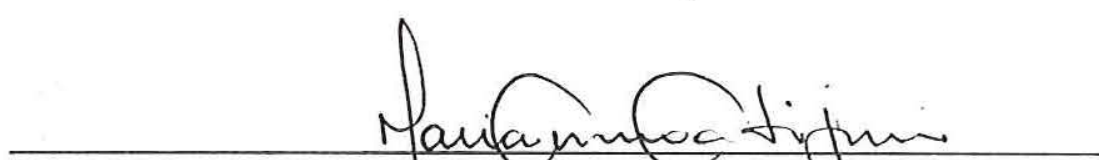

Profa. Assoc. MARIA DO CARMO CALIJURI

Presidente da Comissão de Pós-Graduação da EESC 
"Amigo é coisa para se guardar, do lado esquerdo do peito, dentro do coração" (Milton Nascimento) ... e meu coração é suficientemente grande para todos os amigos que na vida tive a graça de conquistar.

Ofereço esse trabalho a melhoria da qualidade do transporte público da minha querida cidade de Jaú. 
"Quem é como o sábio? Quem conhece a interpretação das coisas como ele? A sabedoria do homem ilumina seu rosto e the abranda a dureza da face"

\section{Eclesiastes}


Agradeço a Deus, por tudo.

Agradeço aos meus pais, Danilo, Áurea, Edward e Stela, pelo apoio.

Agradeço aos meus irmãos, Neury, Cloriza, Ivo, Márcia, Danilo, Rosane, Jorge(in memorian), pelo incentivo.

Agradeço aos meus amigos, Suzana e João, Lidi, Isabela, Patrícia, Bernadete, Fábio, Silvia, Allan, Otávio, Dorival e Marcos pela confiança.

Agradeço ao meu esposo Eduardo, por tanto amor .

Agradeço as minhas filhas, Fernanda e Isabella, pela compreensão.

Agradeço a todos os meus amigos da Prefeitura, Fatec e Departamento de Transportes da EESC-USP, pelo apoio que sempre encontrei.

Agradeço a minha querida amiga Adriane, pela inestimável ajuda na conclusão desse trabalho.

Agradeço ao Prof. Antonio Clóvis Pinto Ferraz, pela amizade, confiança e orientação. 
1.1 Considerações Introdutórias

1.2 Objetivos do trabalho

1.3 Importância do Trabalho

2.1 Breve histórico do transporte por ônibus

2.2 Transporte e Desenvolvimento Urbano

2.3 Funções do Transporte Público

2.4 Propostas para a melhoria do transporte urbano no país

2.4.1 Melhoria da qualidade do transporte coletivo urbano

2.4.1.1 Prioridade de circulação para o transporte coletivo no sistema viário principal

2.4.1.2 Redução dos acidentes e assaltos a passageiros no transporte coletivo

2.4.1.3 Redução do tempo de deslocamento a pé dos usuários de transporte coletivo

2.4.1.4 Elevação da qualidade da gestão de demanda e ofertas

2.4.2 Na redução dos impactos negativos sociais e econômicos das viagens urbanas

2.4.2.1 redução dos efeitos dos congestionamentos nos custos do transporte coletivo urbano

2.4.2.2 Mecanismos para reduzir os impactos dos insumos nos custos operacionais do transporte coletivo urbano 
2.4.2.3 redução dos acidentes com pedestres, ciclistas e pessoas com dificuldade de locomoção

2.4.2.4 acompanhamento e controle permanentes dos níveis aceitáveis de

Qualidade do ar

2.4.3 na modernização das relações institucionais entre órgãos gestores e empresas operadoras de transporte coletivo urbano

2.4.3.1 Adoção de novo modelos de delegação dos serviços e respectiva regulamentação

2.4.3.2 Na modernização tecnológica e gerencial

3. Qualidade do Transporte Público Urbano

3.1 Considerações iniciais

3.2 Fatores de qualidade no transporte público por ônibus

3.3 padrões de qualidade

4 O Sistema Atual do Transporte Público Urbano de Jaú

4.1 Redes e linhas de ônibus

4.2 Pontos de paradas

4.3 Terminal central de integração física das linhas

4.4 Empresa operadora

4.5 Informações gerais do sistema

4.6 Controle da operação

4.7 Pagamento da passagem e controle de acesso

4.8 Sistema de informações aos usuários 
4.9.3 Confiabilidade 36

4.9.4 Lotação 36

4.9.5 Características dos veículos da frota 36

$\begin{array}{lll}\text { 4.9.6 Integração } & 37\end{array}$

4.9.7 Comportamento dos operadores $\quad 37$

$\begin{array}{lll}4.9 .8 & \text { Estado das vias } & 37\end{array}$

5. Avaliação da Qualidade do Transporte Público Urbano em Jaú 38

5.1 Avaliação técnica 38

$\begin{array}{ll}\text { 5.1.1 Acessibilidade a rede de linhas } & 38\end{array}$

5.1.2 Freqüência 41

5.1.3 Tempo de viagem 41

5.1.4 Lotação 41

5.1.5 Confiabilidade 41

$\begin{array}{ll}\text { 5.1.6 Segurança } & 42\end{array}$

5.1.7 Características dos Veículos 42

5.1.8 Características dos locais de parada 42

5.1.9 Sistemas de informação 42

5.1.10 Transbordabilidade $\quad 42$

5.1.11 Comportamento dos operadores $\quad 43$

5.1.12 Estado das vias $\quad 44$

5.2 Avaliação baseada em pesquisa de opinião 44

5.2.1 Pesquisa de opinião com usuários 44

5.2.2 Pesquisa de opinião com pessoas da comunidade 45

5.2.3 Pesquisa de opinião com membros do governo municipal 46 

Urbano em Jaú

7. Considerações Finais

Anexos

Anexo 01- Mapa das linhas de ônibus com identificação da linha, terminal e pontos de parada

Anexo 02- e 03- Resultado de pesquisa de opinião com usuários

Anexo 04- Resultado de pesquisa de opinião com comunidade

Anexo 05- Resultado de pesquisa de opinião com governo

Anexo 06- Modelo de questionário utilizado em pesquisa com usuário

Anexo 07- Modelo de questionário utilizado em pesquisa com comunidade

Anexo 08- Modelo de questionário utilizado em pesquisa com governo municipal

Anexo 09- Mapa de análise do uso e ocupação do solo x rede de transporte público da cidade de Jaú

Anexo 10- Mapa de análise da acessibilidade da rede de transporte público

8. Referências bibliográficas

9. Bibliografia Consultada 


\section{LISTA DE TABELAS}

Tabela 1.1 - Índices de Motorização

Tabela 2.1 - Objetivos e Metas da Política Nacional para transporte urbano. 10

Tabela 2.1 - Diretrizes para melhoria do transporte urbano no país

Tabela 3.1 - Padrões de qualidade no transporte coletivo por ônibus

Tabela 4.1- Características das linhas de ônibus de Jaú( parte 1)

Tabela 4.2- Características das linhas de ônibus de Jaú(parte 2)

Tabela 5.1- Característica do tipo de adensamento por quadra em Jaú

Tabela 5.2-Dados sobre a acessibilidade à rede de transporte coletivo em Jaú

Tabela 5.2.1- Resumo da avaliação técnica da qualidade do transporte coletivo de Jaú

Tabela 5.3 - Resultado da primeira pesquisa de opinião com usuários

Tabela 5.4- Resultado da Segunda pesquisa de opinião com usuários

Tabela 5.5 - Resultado da pesquisa de opinião com comunidade 
Figura 6.2 - Sugestão de readequação arquitetônica. 


\section{RESUMO}

ROMÃO,M.N.P.V.,(2002), Qualidade do transporte público por ônibus na cidade de Jaú São Carlos, Dissertação (Mestrado)- Escola de Engenharia de São Carlos ,Universidade de São Paulo.

No presente trabalho é apresentado um diagnóstico do transporte público coletivo em Jaú, sob a ótica da qualidade, bem como feitas algumas propostas em nível estratégico para a melhoria desse sistema de transporte na cidade. A avaliação da qualidade é feita de forma abrangente, através da comparação das características do sistema existente com padrões de qualidade considerados satisfatórios no meio técnico e aplicação de pesquisa com os usuários, pessoas da comunidade e membros do governo municipal. O diagnóstico mostra que os parâmetros acessibilidade à rede de linhas e comportamento dos operadores apresentam boa qualidade; os parâmetros tempo de viagem, freqüência nos períodos de pico, lotação e estado das vias, qualidade regular; e os parâmetros freqüência nos períodos normais, características dos veículos, características dos pontos de parada, sistema de informação aos usuários e transbordabilidade, qualidade insatisfatória. De maneira geral, a qualidade do sistema de transporte coletivo de Jaú pode ser classificada como regular. As principais diretrizes estabelecidas para a melhoria do sistema são: readequação do desenho da rede de linhas; colocação de rádios de comunicação nos ônibus e implementação de uma central de controle operacional; renovação da frota com a aquisição de ônibus com "design" moderno e tecnologia mais apropriada; sinalização adequada dos pontos de parada e colocação de abrigo e bancos nos locais de maior movimento; colocação do número e do nome das linhas e horários nos pontos de parada; distribuição gratuita de folhetos com os horários e itinerários das linhas; implementação de um novo terminal central fechado para proporcionar integração física e tarifária no sistema; suavizar as valetas e as lombadas mais pronunciadas localizadas nos trajetos dos ônibus e sinalizar adequadamente as vias por onde circulam os ônibus.

Palavras chave: qualidade; usuário; transporte público por ônibus; 
ROMÃO,M.N.P.V.,(2002), Quality of the public transportation by bus in the city of Jaú. São Carlos, Dissertation (Master) - School of Engineering of São Carlos, University of São Paulo.

In the present work a diagnosis of the collective public transportation in Jaú is presented, under the quality optics, as well some proposed in strategic level for the improvement of that transport system.in the city are made. The evaluation of the quality is made in an including way, through the comparison of the existent system characteristics with quality patterns considered satisfactory in the technical area and research application with the users, the community's people and the municipal government's members. he diagnosis shows that the parameters network accessibility of lines and behavior of the operators presents good quality; the parameters time of trip, frequency in the peak periods, capacity and state of the roads, regular quality; and the parameters frequency in the normal periods, characteristics of the vehicles, characteristics of the bus stop, system of information forsers and transbordability, unsatisfactory quality. In a general way, the quality of the public transportation system of Jaú can be classified as regular The main established guidelines for the system improvement : readapt of the network drawing; install radiof communication in the buses and implementation of a operational control headquarters; renewal of the fleet with the bus acquisition with modern "design" and more appropriate technology; appropriate traffic signs in the bus stop and shelter placement and banks in the places of higher movement; placement of the number and of the name of the lines and schedules in the bus stop; free distribution of pamphlets with the schedules and itineraries of the lines; implementation of a new central terminal closed to provide physical and tariff integration in the system; to soften the gutters and more pronounced ramps in the itineraries of the buses and to sign the roads appropriately through circulate the buses.

Key Words: quality; users; public transportation by bus. 


\section{INTRODUÇ̃̃̃O}

\subsection{Considerações introdutórias}

Um sistema de transporte adequado é fator fundamental para o desenvolvimento econômico e social das cidades. A racionalidade, a qualidade e a efíciência do sistema de transporte urbano interferem diretamente na qualidade de vida da população.

Sobre a problemática do transporte público no país, cabe reproduzir o texto a seguir extraído do trabalho de LIMA \& OLIVIERA (2001).

"Os hábitos de deslocamentos da população urbana mudaram significativamente nos últimos10 anos. Há alterações na repartição das viagens entre os diversos modos de transporte. Entre 1995 e 1999 o número de passageiros transportados, por ônibus, nas áreas urbanas, sofreu uma retração de 13,4\%, passando de 16,12 para 13,96 bilhões de passageiros/ano. Ainda maior foi a queda nos sistemas metroferroviários: 27,7\%, no mesmo periodo, de 889 milhões para 643 milhões. Esses passageiros, antes cativos do transporte coletivo, passaram a deslocar-se a pé, por bicicleta e motos (particulares ou de terceiros), motivados pela inadequação da rede de transporte à nova ordem da ocupação urbana. As viagens não motorizadas (por bicicleta ou a pé) aumentaram muito nos últimos 10 anos: dos 20 a 25\% de viagens a pé em relação ao total de viagens diárias realizadas, chegou-se aos patamares de 29 a 50\%. Das viagens por bicicleta não há registros, senão constatação visual de seu aumento em várias cidades do pais. 
Além disso, com o aumento da oferta de veículos em circulação e uma política de ocupação urbana espalhada, aumentaram as distâncias e os tempos de deslocamento, exigindo crescentes intervenções no sistema viário das cidades que, apesar disso, não suportou a demanda. A frota circulante em dezembro de 1999 estava em aproximadamente 27 milhões de veículos; desses, 19 milhões eram automóveis e 244 mil ônibus.

O resultado dessa seqüência de fatos é um colapso na circulação urbana, com sérios prejuizos para a acessibilidade e mobilidade de pessoas e bens, com fortes impactos negativos sociais, econômicos e ambientais para as nossas cidades.

E como decorrência da disputa pelo uso do espaço urbano, entre o transporte individual a pé e motorizado, os atropelamentos assumiram proporções de calamidade social com, aproximadamente, $60 \%$ das vítimas fatais.

Esses problemas setoriais são alguns dos fatores que vêm desintegrando social e economicamente a vida nas cidades, tornando-se fonte de marginalização dos setores mais desfavorecidos e causa de pobreza e desigualdade brutal na forma como as pessoas vivenciam os espaços urbanos.

Dentre as diversas causas de ordem institucional, legal, gerencial e financeira, que poderiam ser apontadas como geradoras desses problemas, consideram-se as de maior importância: falta de articulação entre a gestão urbana e gestão do transporte e trânsito e capacidade de resposta em descompasso com a dinâmica da ocupação dos espaços urbanos, por não se entender a cidade como elemento vivo, dinâmico, cujo crescimento precisa ser monitorado permanentemente; ausência da prioridade necessária no trato com o tema, nos diversos níveis de governo; uso precário dos instrumentos de gestão urbana, dando lugar a crescimento espontâneo, com sérios impactos para a circulação de pessoas e bens e para o meio ambiente."

O excesso de viagens urbanas por automóvel no país exige medidas urgentes no sentido de gerenciar o fluxo veicular nas cidades. Cabe, portanto, às administrações municipais a tarefa de implementar as ações necessárias para neutralizar ou amenizar 
os efeitos nocivos decorrentes do crescimento da frota circulante: congestionamentos e lentidão do trânsito, poluição, uso indiscriminado de energia automotiva, acidentes, etc.

As cidades brasileiras, assim como as dos demais países em desenvolvimento, apresentam graves problemas de transporte e qualidade de vida. Queda na mobilidade e acessibilidade, degradação das condições ambientais, congestionamentos crônicos e altos índices de acidentes de trânsito já se tornaram rotina em muitas cidades.

Essa situação decorre de muitos fatores sociais, políticos e econômicos, mas deriva também de decisões passadas relativas às políticas urbanas de transporte e trânsito.

Com o crescimento desenfreado da frota de automóveis particulares, houve grandes investimentos no sistema viário buscando a fluidez do trânsito, formando a cultura do automóvel. Com isso, o transporte público entrou em declínio de importância, tanto na sua eficiência quanto na sua confiabilidade junto ao público. Em conseqüência, hoje a realidade nacional é que a grande massa da população de menor renda - usuária do transporte público - encontra-se limitada nos seus direitos de mobilidade e acessibilidade.

"A situação do transporte público tende a se agravar: a falta de transporte público de qualidade estimula o uso do transporte individual, que aumenta os níveis de congestionamento e a poluição. Esse uso ampliado do automóvel estimula no médio prazo a expansão urbana e a dispersão das atividades, elevando o consumo de energia e criando grandes diferenças de acessibilidade às atividades". ANTP (2001).

De acordo com FERRAZ \& TORRES (2001), sabe-se que o uso massivo do automóvel traz uma série de problemas às cidades. Seguem os principais:

- Congestionamentos e lentidão do trânsito;

- Poluição ambiental; 
- Uso indiscriminado de energia automotiva, que compromete o desenvolvimento sustentável, pois a maior parte da energia consumida é proveniente de derivados de petróleo;

- Elevado número de acidentes de trânsito;

- Necessidade de grandes investimentos do setor público na infra-estrutura viária, em detrimento de outros setores da sociedade, como saúde, educação, etc.

"As dificuldades nos deslocamentos de pessoas e mercadorias, aliadas aos acidentes de trânsito e à poluição atmosférica, deverão agravar-se, à medida que a urbanização prosseguir e a economia crescer: As cidades maiores terão seus problemas, custos e deseconomias aumentadas exponencialmente e as cidades médias começaram a vivenciar graves problemas de deslocamento de pessoas $e$ mercadorias". ANTP (1999).

Nesse contexto, a melhoria da qualidade e da eficiência do transporte público aparece como uma importante alternativa visando a redução do número de viagens por automóvel. Um transporte público com melhor qualidade e eficiência acaba por atrair usuários do transporte individual.

Também de extrema relevância é o fato de que a melhoria do sistema de transporte público urbano reverte diretamente na melhoria da qualidade de vida da população de menor poder aquisitivo, que é usuária cativa do transporte coletivo.

Algumas vantagens do transporte coletivo sobre o transporte individual, citadas por FERRAZ \& TORRES (2001), são a seguir reproduzidas.

"O consumo de espaço viário por passageiro transportado é aproximadamente 18 vezes maior no transporte por automóvel em relação ao ônibus convencional quando considerado o eixo carroçável. Este valor sobe para 27 se for considerada a área ocupada pelo veículo particular para estacionar junto ao meio fio. Quando é feita a análise do aspecto consumo de energia por passageiro transportado, que é cerca de 5 vezes maior no transporte por automóvel em relação ao ônibus. E no item poluição 
atmosférica, os resultados também são favoráveis aos ônibus. Como a emissão de poluentes depende do tipo e qualidade do combustivel utilizado e da eficiência dos dispositivos veiculares antipoluentes, é dificil citar valores genéricos. Na realidade, o ônibus perde para o automóvel apenas no que tange à poluição sonora. Contudo, o desenvolvimento tecnológico vem conseguindo reduzir rapidamente o nivel de ruido emitido pelos ônibus através do encapsulamento dos motores e outros aperfeiçoamentos".

A cidade ideal - aquela que apresenta organização institucional, infra-estrutura, serviços públicos, condições ambientais, etc. adequados - não existe, pois toda cidade tem problemas. No entanto, deve-se sempre buscar a cidade ideal, através de planejamento e ações em todos os níveis.

\subsection{Objetivos do trabalho}

O presente trabalho tem como objetivos:

- Fazer um diagnóstico da situação atual do transporte público coletivo na cidade de Jaú, sob a ótica da qualidade;

- Propor ações para a melhoria da qualidade do transporte público por ônibus na cidade de Jaú.

A avaliação da qualidade será feita de forma abrangente, conforme a seguinte estratégia:

- Comparação das características do sistema existente com padrões de qualidade considerados satisfatórios no meio técnico;

- Aplicação de pesquisa com os usuários;

- Aplicação de pesquisa com pessoas da comunidade;

- Aplicação de pesquisa com membros do governo municipal. 


\subsection{Importância do trabalho}

A frota veicular de Jaú é de 49.483 veículos de acordo com dados do cadastro do Departamento Estadual de Trânsito - SP (2002)1. A população do município é de 112.000 habitantes (IBGE, 2000). Assim, o índice de motorização no município é de 441,813 veículos/1000 habitantes.

A tabela 1.1 apresenta os índices de motorização de alguns países, onde se pode observar que a taxa de Jaú é muito próxima a de alguns países europeus, que apresentam um índice elevado de veículos por habitante.

Tabela 1.1 - Índices de Motorização. Fonte: Vuchic (2000).

\begin{tabular}{|l|c|}
\hline \multicolumn{1}{|c|}{ País } & $\begin{array}{c}\text { Veículos por mil } \\
\text { habitantes }\end{array}$ \\
\hline Cuba, Índia e outros países. & $<100$ \\
\hline Grécia & $100-200$ \\
\hline Portugal e Brasil* & $200-300$ \\
\hline Dinamarca, Japão, Espanha, Holanda, Noruega e Finlândia. & $300-400$ \\
\hline Bélgica, Inglaterra, Áustria, França, Suécia e Austrália. & $400-500$ \\
\hline Itália e Estados Unidos & $>500$ \\
\hline
\end{tabular}

- Informação acrescentada pela autora.

O elevado índice de motorização existente na cidade de Jaú se traduz num exagerado número de viagens de automóvel por habitante.

Por outro lado, o sistema de transporte público por ônibus da cidade apresenta qualidade e eficiência que, visivelmente, deixam a desejar.

Dessa forma, é de suma importância que seja reavaliado o modelo de transporte e circulação da cidade, de tal forma a garantir uma melhor distribuição de deslocamento ao lado de uma maior eficiência que pode ser obtida se o processo de

\footnotetext{
${ }^{1}$ Dados disponíveis na Prefeitura Municipal de Jaú, através de convênio firmado com a Secretaria de Segurança Pública que estabeleceu a Municipalização do Trânsito dessa cidade.
} 
desenvolvimento urbano e as políticas de transporte e trânsito forem revistas, gerando um equilíbrio entre os modos que otimize a produtividade do sistema e promova condições adequadas para os usuários.

Tais políticas devem ser adotadas de forma a garantir:

- Melhor qualidade de vida para a população da cidade;

- Eficiência da infra-estrutura e dos serviços públicos da cidade;

- Minimização dos impactos ambientais.

Em vista do exposto, não resta dúvida que o presente trabalho, ademais de cumprir a sua finalidade acadêmica, é de grande interesse para a cidade de Jaú, por tratar de um tema de grande relevância para a qualidade de vida de sua população.

\subsection{Estrutura do trabalho}

O trabalho encontra-se estruturado da forma exposta a seguir.

No capítulo1 são apresentadas as considerações introdutórias ao assunto e colocados os objetivos e a importância do trabalho.

No capítulo 2 são discutidos alguns aspectos do transporte relativos ao transporte público urbano considerados relevantes no contexto do trabalho.

O capítulo 3 aborda a questão da qualidade no transporte público urbano, enfocando o ponto de vista dos usuários e dos outros atores envolvidos com este modo de transporte: comunidade, funcionários do setor, empresários do ramo e governo.

O capítulo 4 contém uma descrição do sistema de transporte público coletivo existente na cidade de Jaú.

No capítulo 5 são apresentados os resultados da avaliação da qualidade do sistema de transporte público de Jaú. Essa avaliação é feita com base em critérios técnicos e, 
também, baseada nos resultados de pesquisas de opinião com usuários, pessoas da comunidade e membros do governo municipal.

O capítulo 6 reúne um elenco de ações a nível estratégico, propostas para a melhoria da qualidade do sistema de transporte público por ônibus na cidade de Jaú.

No capítulo 7 são feitas algumas considerações finais consideradas relevantes no contexto do trabalho. 


\section{Alguns aspectos Sobre o Transporte Público URBANO}

\subsection{Breve histórico do transporte por ônibus}

Antes do século XVII, o deslocamento das pessoas nas cidades era realizado a pé, montado em animal ou em carruagem puxada por animais, que apenas os mais abastados possuíam. As carruagens de aluguel puxadas por animais, que surgiram nas cidades de Londres em 1600 e Paris 1612, podem ser considerados os primeiros serviços de transporte público urbano. VUCHIC (2001), FERRAZ \& TORRES (2001).

Somente em 1662, quando a população de Paris era de 150 mil habitantes, é que Blaise Pascal organizou o primeiro serviço regular de transporte público.

Em 1826, foi criado em Nantes-França uma linha de transporte por carruagens de grande tamanho que ligava a cidade a uma casa de banhos. Essas carruagens foram denominadas à época de "omnibus".

Ainda no ano de 1832, surgem em Nova Iorque os bondes rebocados por animais, que evoluíram na última década do século XIX para os bondes com motor elétrico.

Finalmente, em 1890, surgem na Inglaterra, Alemanha e França, os primeiros ônibus com propulsão mecânica. 


\subsection{Transporte e desenvolvimento urbano}

O transporte é uma atividade que interage diretamente com o desenvolvimento e a organização das cidades. Assim, planejada ou anarquicamente construída, a cidade vai crescendo, mais ou menos competitiva, com maior ou menor qualidade de vida. O certo é que uma cidade mais humana nasce de uma visão integrada das suas funções e é resultado de uma gestão compartilhada entre os distintos órgãos responsáveis pelo desenvolvimento urbano: habitação, transporte, trânsito, educação, meio ambiente etc.

Como não se exercitou essa integração, registram-se fenômenos que seguramente não foram previstos pelos planejadores urbanos, muito menos pelos órgãos executores de políticas setoriais, apesar da grande competência técnica que eles acumularam nas últimas décadas. Buscar modelos institucionais, legais e financeiros que estimulem essa articulação e integração, a partir da análise de experiências que estão dando certo, deverá ser um dos maiores desafios dos setores de planejamento, no cumprimento das suas competências.

Nesse contexto, de dimensão e importância significativas para o desenvolvimento urbano, foi elaborada pelo governo brasileiro - SEDU (2001) - uma proposta de Política Nacional para o Transporte Urbano, com os objetivos e metas relacionados na tabela 2.1 .

Tabela 2.1 - Objetivos e metas da política nacional para transporte urbano.

Fonte: SEDU (2001).

\begin{tabular}{|l|l|}
\hline \multicolumn{1}{|c|}{ Objetivos } & \multicolumn{1}{|c|}{ Metas } \\
\hline $\begin{array}{l}\text { Aumentar a atratividade do transporte } \\
\text { coletivo. }\end{array}$ & $\begin{array}{l}\text { Tornar o transporte coletivo mais rápido, } \\
\text { confortável, acessível, seguro e adequado às } \\
\text { necessidades de deslocamento da população. }\end{array}$ \\
\hline $\begin{array}{l}\text { Reduzir os impactos negativos econômicos, } \\
\text { sociais e ambientais das viagens urbanas. }\end{array}$ & $\begin{array}{l}\text { Reduzir tempos de viagem e custos } \\
\text { operacionais do transporte coletivo, acidentes } \\
\text { de trânsito (especialmente com pedestres e } \\
\text { ciclistas) e poluição atmosférica. }\end{array}$ \\
\hline $\begin{array}{l}\text { Modernizar as relações institucionais entre } \\
\text { órgãos gestores e empresas operadoras de de } \\
\text { onnibus. }\end{array}$ & $\begin{array}{l}\text { Implementar uma visão mercadológica entre: } \\
\text { Poder Público, Agente Operador e Sociedade } \\
\text { (usuários diretos, indiretos e potenciais dos }\end{array}$ \\
\hline
\end{tabular}




\begin{tabular}{|l|l|}
\hline $\begin{array}{l}\text { Estimular a modernização tecnológica e } \\
\text { gerencial do transporte coletivo. }\end{array}$ & transportes públicos). \\
\hline $\begin{array}{l}\text { Assegurar um crescente grau de satisfação da } \\
\text { sociedade e dos usuários com os serviços que } \\
\text { lhe são prestados e integrar as políticas e e } \\
\begin{array}{l}\text { ações públicas entre o transporte urbano e os orte coletivo mais eficiente. } \\
\text { demais setores. }\end{array}\end{array}$ & $\begin{array}{l}\text { Criar condições para que esse transporte } \\
\text { coletivo seja elemento de competitividade } \\
\text { das cidades brasileiras e se constitua em } \\
\text { instrumento de promoção do do de } \\
\text { desenvolvimento sustentável dessas cidades. }\end{array}$ \\
\hline
\end{tabular}

\subsection{Funções do transporte público}

O transporte público urbano visa transportar várias pessoas juntas no mesmo veículo, com o objetivo de oferecer um serviço de baixo custo, atendendo, assim, a necessidade das pessoas de menor poder aquisitivo no acesso aos locais de trabalho, estudo, lazer, compras e serviços em geral.

De acordo com FERRAZ \& TORRES (2001), além de promover o transporte da população de baixa renda, o transporte coletivo também proporciona mobilidade às pessoas que não podem ou não desejam dirigir pelos mais variados motivos. Nas grandes cidades, também representa uma alternativa de locomoção que contribui muito para a melhoria da qualidade de vida, à medida que reduz significativamente a poluição atmosférica, os congestionamentos, os acidentes, o consumo de energia, etc.

De outro lado, o transporte público coletivo constitui um fator determinante na ordenação e estruturação da ocupação e uso do solo, pois favorece o adensamento populacional e a concentração de comércio e serviços em locais adequados.

Os custos do transporte urbano englobam investimentos, a manutenção e a operação da infra-estrutura viária (vias, dispositivos de controle, sinalização, estacionamentos, etc.), das vias especificas de transporte público, dos veículos privados e públicos.

Conforme FERRAZ \& TORRES (2001), alguns estudos feitos indicam que nas grandes cidades o custo do transporte público urbano (investimento, operação e manutenção) é próximo da soma dos custos dos outros serviços públicos básicos: 
abastecimento de água, coleta de esgoto, iluminação pública, telefone, habitação, drenagem, pavimentação, fornecimento de energia elétrica, etc.

O transporte de passageiros pode ser feito através de diversos modos, mas, nenhum revolucionou tanto a acessibilidade e a mobilidade como o ônibus, que persiste ao longo de muitos anos. Esse veículo sobreviveu à concorrência com os bondes, devido à facilidade de trafegar em qualquer tipo de via e ao baixo investimento necessário.

"Nos municípios brasileiros a operação e a gestão dos transportes públicos apresentam limitações no que concerne à busca dos índices de produtividade, sobretudo porque a regulamentação em vigor no país inibe a competitividade entre as empresas, na disputa pelo direito de operar o serviço, mecanismo fundamental de garantia de redução de custos, de aumento de produtividade e de melhor qualidade de serviço ofertado à população". BRASILEIRO (1996).

ARAGÃO, BRASILEIRO, SANTOS \& ORRICO (2000) colocam que o transporte de passageiros está passando por uma fase de redefinição, devido à migração de passageiros para outros modos de transporte: privado, clandestino ou à pé; sendo que a liderança do setor reconhece a ineficiência do mesmo, que apresenta baixos níveis de qualidade e produtividade.

MENDES (1999) cita a mobilidade no espaço urbano regional ou nacional, e a considera um assunto em constante avaliação por parte da população. Particularmente dentro das cidades, o tempo e o conforto dos deslocamentos são objeto de críticas constantes. A velocidade de deslocamento, segundo o autor, é uma dimensão importante na avaliação da qualidade de vida das cidades.

Não é fácil modelar a mobilidade, quer pelas diferentes perspectivas que pode ser abordada, quer pelos níveis territoriais, ou ainda pela indisponibilidade de dados resultantes de medições objetivas nas cidades. É importante contemplar a disponibilidade de transportes públicos, o congestionamento das vias e o sistema viário como um todo. Dessa forma, em cidade maiores verifica-se maiores 
disponibilidades de transporte público, o que não ocorre nas menores, por estarem menos pressionadas pelo congestionamento, induzindo a um transporte público de menor qualidade e eficiência.

\subsection{Propostas para a melhoria do transporte urbano no país}

A tabela 2.2 contém algumas diretrizes para a melhoria do transporte urbano no país, de acordo com o plano elaborado por SEDU (2001).

Tabela 2.2 - Diretrizes para a melhoria do transporte urbano no país. Fonte: SEDU (2000).

\begin{tabular}{|c|c|}
\hline ITENS & DIRETRIZES \\
\hline $\begin{array}{l}\text { Melhoria da qualidade do } \\
\text { Transporte coletivo urbano }\end{array}$ & $\begin{array}{l}\text { - Prioridade de circulação para o transporte } \\
\text { coletivo no sistema viário; } \\
\text { - Redução dos acidentes e assaltos no transporte } \\
\text { coletivo; } \\
\text { - Redução do tempo de deslocamento a pé e } \\
\text { alternativas para deslocamento dos deficientes e } \\
\text { ciclistas; e } \\
\text { - Elevação da qualidade da gestão de demanda e } \\
\text { oferta. }\end{array}$ \\
\hline $\begin{array}{l}\text { Redução dos impactos } \\
\text { Negativos sociais, econômicos e } \\
\text { ambientais das viagens urbanas }\end{array}$ & $\begin{array}{l}\text { - Ações para minimizar os efeitos dos } \\
\text { congestionamentos nos custos do transporte; } \\
\text { - Mecanismos para reduzir os impactos dos } \\
\text { insumos nos custos operacionais; } \\
\text { - Medidas para reduzir os acidentes com } \\
\text { pedestres, ciclistas e pessoas com dificuldade } \\
\text { de locomoção; e } \\
\text { - Instrumentos técnicos para acompanhamento e } \\
\text { controle permanentes dos níveis de qualidade } \\
\text { do ar. }\end{array}$ \\
\hline
\end{tabular}




\begin{tabular}{|c|l|l|}
\hline Modernização das & $\begin{array}{l}\text { Mecanismo legal que defina claramente as } \\
\text { responsabilidades do concessionário e do poder } \\
\text { concedente, com vistas à redução dos custos } \\
\text { operacionais e à melhoria da Qualidade dos } \\
\text { serviços; }\end{array}$ \\
Relações institucionais & $\begin{array}{l}\text { Mecanismo administrativo que permita o } \\
\text { controle social do desempenho dos mesmos; } \\
\text { Mecanismo contratual que ofereça segurança de } \\
\text { retorno do investimento no setor e definam } \\
\text { indicadores e padrão de desempenho e } \\
\text { qualidade a fim de permitir avaliação; } \\
\text { Visão mercadológica, a fim de permitir maior } \\
\text { flexibilidade para que a empresa operadora } \\
\text { tenha condições para gerenciar a demanda e } \\
\text { adequa-la com presteza e rapidez; } \\
\text { Medidas de fidelização do usuário por meio de } \\
\text { ganhos de credibilidade. }\end{array}$ \\
\hline
\end{tabular}

As principais propostas da Política Nacional para o Transporte Urbano estabelecidas por SEDU (2001) são colocadas a seguir.

\subsubsection{NA MELHORIA DA QUALIDADE DO TRANSPORTE COLETIVO URBANO}

2.4.1.1. Prioridade de circulação para o transporte coletivo no sistema viário principal.

- Induzir o desenvolvimento de modelos de delegação que favoreçam os investimentos em corredores estruturais de transporte coletivo, promover campanhas de marketing institucional para sensibilizar a sociedade sobre a eficiência do transporte coletivo e rever prioridades de investimentos pelo governo federal, no setor.

- Potencializar o controle de acesso e/ou bilhetagem automática como instrumentos de política tarifária e de gestão da ocupação urbana. Essa medida deve ser equilibrada com políticas visando minimizar os impactos sociais em relação à categoria cobrador.

\subsubsection{Redução dos acidentes e assaltos a passageiros no transporte coletivo}


Incorporar o tema segurança de transporte coletivo urbano nas ações contempladas pelo Plano Nacional de Segurança, com base em um diagnóstico nacional do problema de segurança do transporte coletivo e incentivar a implantação de tecnologias que contribuam para:

- diminuir o manuseio de valores no interior dos veículos de transporte coletivo e;

- melhorar as condições de trabalho do pessoal operacional.

\subsubsection{Redução do tempo de deslocamento a pé dos usuários de Transporte} Coletivo

- Urbano e criação de alternativas para deslocamento dos deficientes e ciclistas;

- Induzir a inserção da prioridade para a circulação de pedestres, nos projetos de infra-estrutura, nos acessos ao transporte coletivo e a construção de ciclovias integradas às redes de transporte público, bem como a criação de serviços especiais para pessoas portadoras de deficiência, programados em função da demanda e com utilização de veículos adaptados.

\subsubsection{Elevação da qualidade da gestão de demanda e oferta}

- Promover a capacitação para revisão dos modelos organizacionais do transporte coletivo urbano, admitindo o emprego de diferentes tecnologias veiculares e de controle operacional numa mesma delegação, incluindo-se o estabelecimento de estruturas tarifárias diversificadas e integradas que incentivem a captação da demanda dos diferentes horários e dias da semana; fomentar o conhecimento das demandas dos usuários e não usuários do transporte coletivo; desenvolver programas destinados a aumentar o nível de informação; aperfeiçoar o conhecimento dos prefeitos, gestores estatais e legisladores a respeito do marco legal dos transportes, bem como estimular o desenvolvimento de programas de qualidade e produtividade pelos órgãos gestores. 


\subsubsection{NA REDUÇÃO DOS IMPACTOS NEGATIVOS SOCIAIS E ECONÔMICOS DAS VIAGENS URBANAS}

\subsubsection{Redução dos efeitos dos congestionamentos nos custos do transporte coletivo urbano}

- Promover políticas de gestão territorial municipal e controle do uso do solo que privilegiem a utilização do transporte coletivo urbano e o aumento da sua fluidez, para elevação da sua velocidade operacional, por meio da criação de corredores exclusivos dotados de sinalização eletrônica ou alguma outra forma de prioridade de circulação, bem como de manutenção permanente do sistema viário utilizado pelo transporte coletivo urbano.

\subsubsection{Mecanismos para reduzir os impactos dos insumos nos custos operacionais do transporte coletivo urbano}

- Induzir a elevação da produtividade do capital e da mão de obra e apoiar regulamentação que impute os custos das gratuidades aos responsáveis por elas, que mantenha, expanda e melhore o controle do Vale Transporte e que acabe com a evasão de receitas.

\subsubsection{Redução dos acidentes com pedestres, ciclistas e pessoas com dificuldade} de locomoção

- Criar programas de investimentos em: i) infra-estrutura física (calçadas, guias rebaixadas, remoção de barreiras físicas) e operacional (sinalização horizontal e vertical educativa e de orientação para pedestres); ii) sinalização vertical educativa para pessoas com dificuldade de locomoção; e iii) facilidades de deslocamento para proteção ao ciclista em suas viagens motivo trabalho; e iv) apoiar campanhas para motivar e sensibilizar a população e empresas para a manutenção e limpeza de vias, calçadas, ciclovias, áreas públicas e mobiliário urbano. 
2.4.2.4. Acompanhamento e controle permanentes dos níveis aceitáveis de qualidade do ar

- Fomentar parcerias com o Ministério do Meio Ambiente - Programa de Qualidade Ambiental (PQA/SQA/MMA), o Ministério de Minas e Energia / CONPET e organismos locais (municipais e estaduais) com vistas à execução de programas de redução da poluição do ar e fomentar a criação de programas de financiamento, com juros reduzidos, para renovação de frota com a adoção de "tecnologias limpas".

\subsubsection{NA MODERNIZAÇÃO DAS RELAÇÕES INSTITUCIONAIS ENTRE ÓRGÃOS GESTORES E EMPRESAS OPERADORAS DE TRANSPORTE COLETIVO URBANO}

\subsubsection{Adoção de novos modelos de delegação dos serviços e respectiva} regulamentação

- Adoção de modelos de concessões orientados pelos desejos dos usuários atuais e potenciais, com prazos compatíveis com o tamanho do sistema; que defina os riscos do concessionário (de tarifa, de custo, de demanda) e do poder concedente; que defina e especifique melhor as atribuições de cada parte, bem como as características da oferta dos serviços, adequando-a às peculiaridades da demanda; que estimule o controle dos serviços por meio de índices de eficácia e efíciência e da participação social; e que permita a diferenciação de tarifas para viabilizar a diversificação da oferta. 


\subsubsection{Na modernização tecnológica e gerencial}

\section{Comunicação com o usuário}

- Adotar como princípio que a comunicação com o usuário deva se dar em duas vias: uma do entendimento das necessidades, outra de informação; e promover pesquisas regionalizadas de opinião, satisfação e imagem do transporte coletivo urbano, com vistas ao realinhamento de políticas e diretrizes, com amplo processo de divulgação dos resultados.

\section{$\underline{\text { Tecnologia veicular }}$}

- Estimular o desenvolvimento de produtos com base no conhecimento e no entendimento das necessidades do cliente (tanto usuários do transporte coletivo urbano, como profissionais que gerenciam o transporte público);

- a criação de linhas de financiamento específicas e diferenciadas, não limitadas apenas a sistemas integrados, estendendo-se inclusive a veículos de diferentes capacidades e tecnologias que atendam às variações de mercado; e

- a utilização de veículos de baixa emissão de poluentes, por meio do desenvolvimento de sistema que adote o bônus verde ou moeda verde, traduzida em créditos ambientais, tecnicamente calculados a partir da redução da emissão veicular de poluentes e de metas estabelecidas.

\section{Gestão Pública e Privada}

- Induzir e apoiar a profissionalização da gestão das empresas operadoras, pelo poder concedente, mediante incentivos no processo licitatório, indicadores contratuais da avaliação de qualidade da gestão e políticas de remuneração diferenciada, garantidas em instrumentos contratuais; estabelecer padrões de qualidade (com o uso de indicadores) para a gestão pública de sistemas de transporte; firmar parcerias com universidades ou centros de educação 
tecnológica públicos, visando capacitação em Gestão de Transporte Público Urbano; e adotar a melhoria contínua e a busca da excelência como princípios institucionais e permanentes desafios para a gestão empresarial. 


\section{Qualidade no Transporte PÚblico Urbano}

\subsection{Considerações iniciais}

"Visando acompanhar as mudanças urbanas que vêm ocorrendo nas cidades brasileiras e os seus reflexos na mobilidade da população, o transporte coletivo urbano precisa necessariamente se adequar às novas realidades". RAIA JR. (1998); RAIA JR. \& MOREIRA (2000).

"Dessa forma, a adoção da filosofia da Qualidade é um aspecto imperativo para que as empresas de ônibus possam sobreviver num mercado que tende ser sempre mais competitivo. Apesar da crescente utilização da filosofia da Qualidade, em termos gerais, sua aplicação em empresas operadoras está embrionária." OBENG \& UGBORO (1996), apud RAIA JR. (1998).

"Os órgãos gestores e operadoras necessitam manter contatos regulares e sistemáticos com a comunidade para conhecer suas exigências e necessidades e sua opinião sobre a qualidade dos serviços ofertados". (RAIA JR. (1999); RAIA JR. \& MOREIRA (2000).

"As operadoras privadas têm como objetivo a lucratividade do seu investimento, obviamente dentro dos parâmetros estabelecidos pelo Órgão Gestor. Os usuários, por sua vez, almejam o melhor nivel de qualidade possivel, a partir de seus referenciais de avaliação, tais como conveniência, rapidez, acessibilidade, confiabilidade, conforto, etc.". CANÇADO (1996), apud RAIA JR. \& MOREIRA (2001). 
Segundo ANTP (1995), existem vários modos de se conhecer as necessidades e os requisitos de transporte de grupos sociais urbanos: através de indicadores sócioeconômicos, através de contatos diretos com a comunidade organizada e através de pesquisas junto à população, onde ela mesma expõe sua realidade, expectativas, interesses e opiniões. O conhecimento sobre o usuário, suas expectativas e opiniões são fundamentais para a adoção de melhores e mais acertadas decisões gerenciais, evitando a implementação de ações equivocadas, fundamentando uma atuação mais eficaz no processo permanente de se atingir a plena satisfação dos usuários.

"Um dos fundamentos da Gestão da Qualidade - a qualidade centrada no cliente está embasado no fato da empresa procurar conhecer como seus clientes avaliam as características básicas e relevantes do serviço ofertado e o que thes adicionam valores. Os resultados dessa avaliação devem ser utilizados para a implementações de ações que venham a proporcionar o fortalecimento das relações com os clientes (usuários), melhorando a sua satisfação. Além disso, os resultados das pesquisas de opinião dos usuários servirão para apoiar a empresa no seu planejamento relativo ao cliente e mercado." (RAIA JR. \& MOREIRA, 2000).

De acordo com FERRAZ \& TORRES (2001), a qualidade no transporte público urbano dever ser contemplada com uma visão total e global do sistema. Deve considerar a eficiência e a eficácia individual e conjunta de todas as etapas e ações que envolvem a prestação deste serviço, assim como a satisfação dos atores direta ou indiretamente envolvidos no processo: usuários, comunidade, trabalhadores, empresários e governo. Este é o enfoque que se pode denominar de qualidade total no transporte público urbano. Para se obter qualidade total, é fundamental que cada um dos 5 atores citados, conheçam suas tarefas, objetivos, direitos e obrigações, isto é, que haja a capacitação do sistema.

Os usuários do transporte público exercem pressão permanente no Governo para que o mesmo tenha tarifa baixa e boa qualidade, mas ao mesmo tempo a competição com esse modo de transporte é grande, pelos automóveis, motos, lotações, moto-táxi, etc, que se tornam mais acessíveis devido a redução dos preços. 
Desta forma é de interesse a todos os envolvidos no transporte público que ele tenha eficiência e qualidade, pois desta forma eles melhoram a imagem do governo, a da empresa e mantém seus empregos. Portanto existe uma necessidade quase constante em se investir na qualidade e na eficiência, a fim de manter os atuais usuários e buscar futuros usuários, visando sustentar uma tarifa acessível para a população de baixa renda. Existe uma estreita relação entre qualidade e custo, pois a melhoria da qualidade implica em aumento de custo e vice-versa, no entanto a definição do nível do patamar da qualidade é vital para a sobrevivência do sistema, considerando o usuário de menor poder aquisitivo é que faz a razão de ser do transporte público coletivo.

Dois importantes aspectos relacionados com a qualidade do transporte urbano são a acessibilidade e a mobilidade. Seguem considerações a respeito desses parâmetros.

"A acessibilidade está relacionada com a oportunidade que um individuo, em um dado local, possui para tomar parte em uma atividade particular ou uma série de atividades. Está relacionada à mobilidade do indivíduo ou tipo de pessoa, à localização espacial de oportunidades relativas ao ponto de partida do individuo, às vezes em que o individuo está disponivel para participar das atividades $e$, às vezes em que as atividades estão disponíveis. Assim a acessibilidade está relacionada não com o comportamento propriamente dito, mas com a oportunidade ou potencial, disponibilizados pelo sistema de transporte e uso do solo, para que diferentes tipos de pessoas desenvolvam suas atividades." BOCANEGRA (2002)

"Acessibilidade: facilidade dos usuários alcançarem os destinos pretendidos, traduzida pela coincidência dos itinerários com os desejos dos usuários. TEIXEIRA, KIRIHATA, SENNE E DIAS (2001)

SANCHES (1996) afirma que "para a avaliação da qualidade do transporte nas cidades, os indicadores de acessibilidade baseados no tempo de viagem e que consideram também a atratividade das diversas zonas, são os mais adequados. Por 
incorporarem, tanto aspectos relacionados com o sistema de transporte, quanto aspectos da distribuição de atividades no espaço, estes indicadores permitem analisar a adequação da estrutura do sistema à distribuição espacial de usos de solo, em termos da acessibilidade fornecida ao usuário"

A mobilidade é caracterizada pelo grau de facilidade para locomoção de um local a outro da cidade, se possível com uma única viagem. Como o custo do transporte se torna mais alto é avaliado considerando a existência ou não de integração física e tarifária no sistema de transporte público urbano.

MENDES (1999) mostra que a mobilidade no espaço urbano é um assunto em constante avaliação por parte da população, onde o tempo e o conforto nos deslocamentos são objeto permanente de crítica pela população.

"A mobilidade é a capacidade de um individuo ou tipo de pessoa de se deslocar. Isto envolve dois componentes: o primeiro, depende da performance do sistema de transporte, e que é afetado por onde a pessoa está, da hora do dia e a direção na qual se deseja deslocar; o segundo componente depende das características do indivíduo, tais como: se ele tem carro próprio, disponibilidade de recursos para pagar táxi., ônibus, trem ou avião; se tem a possibilidade de caminhar ou usar o transporte público e mesmo se tem conhecimento das opções disponiveis para ele. Em outras palavras, o primeiro elemento está relacionado com a efetividade do sistema de transporte em conectar localidades especialmente separadas, e o segundo elemento está associado com até que ponto um determinado individuo ou tipo de pessoa é capaz de fazer o uso do sistema de transporte." BOCANEGRA (2002).

Pode-se identificar três níveis de relacionamento entre as variáveis associadas ao sistema de atividades e ao sistema de transporte, que são:

- interação espacial, cuja magnitude evidencia-se pelo número de viagens realizadas

- acessibilidade, cujo índice reflete um potencial de interação espacial; e

- mobilidade, cuja medida traduz o grau de impedância ao deslocamento. 
Outro fator importante no tocante à qualidade é a existência de integração tarifária no sistema. Seguem comentários a respeito.

A integração tarifária pode ser realizada de diversas formas:

- Terminais fechados: é permitido aos usuários que estão dentro do terminal o embarque pelas portas de desembarque do veículo, pois os mesmos já pagaram a passagem no primeiro veículo que utilizaram ou ao ingressar no terminal;

- Integração com bilhete: o embarque é feito normalmente e o bilhete é entregue ao cobrador, ao motorista ou introduzido em uma catraca automática;

- Catracas eletrônicas com sistema de leitura ótica: as informações são gravadas em bilhetes especiais, que assinalam o horário da primeira viagem e fixam, automaticamente, o limite de tempo para o início da segunda viagem;

- Cartões de crédito de viagens: a utilização do transporte público é concretizado através de gravações magnéticas em cartões feita com máquinas especiais mediante pagamento. Neste caso, as próprias leitoras acopladas as catracas instaladas nos ônibus controlam seu uso, pois as informações de horário podem ser gravadas no próprio cartão.

\subsection{QUALIDADE DO PONTO DE VISTA DOS USUÁRIOS}

De acordo com FERRAZ \& TORRES (2001), os seguintes parâmetros afetam a qualidade do transporte público urbano por ônibus: acessibilidade, freqüência, tempo de viagem, lotação, confiabilidade, segurança, características dos veículos e dos pontos de parada, sistema de informação, transbordabilidade, comportamento dos operadores e estado das vias.

Segue um resumo das considerações feitas por FERRAZ e TORRES (2001) sobre 
cada um desses fatores.

\section{Acessibilidade}

A acessibilidade está associada à distância percorrida para iniciar e finalizar a viagem por transporte público e à comodidade experimentada nesses percursos.

No caso usual em que esses percursos são realizados a pé, são relevantes na caracterização da acessibilidade os seguintes fatores: distância percorrida e a dificuldade na caminhada, seja pela declividade do percurso, existência ou não de calçamento nos passeios, estado das calçadas e facilidade para cruzar as ruas existentes no trajeto.

\section{Freqüêencia de atendimento}

A freqüência de atendimento está relacionada com o intervalo de tempo entre passagens dos veículos de transporte público, o qual afeta diretamente o tempo de espera nos locais de parada para os usuários que não conhecem os horários e chegam aleatoriamente aos mesmos, bem como reduz a flexibilidade de utilização do sistema para os usuários que conhecem os horários.

\section{Tempo de viagem}

O tempo de viagem corresponde ao tempo gasto no interior dos veículos e depende da velocidade média de transporte.

A velocidade média de transporte depende do grau de separação da via de transporte público do tráfego geral, da distância entre os locais de parada, das condições da superficie de rolamento, das condições do trânsito e do tipo de tecnologia dos veículos. 


\section{Lotação}

A lotação corresponde à quantidade de passageiros no interior dos veículos de transporte público.

O ideal seria que todos os passageiros pudessem viajar sentados, o que implicaria em tarifas muito elevadas. Assim, é aceitável parte dos usuários viajando em pé, desde que em número não excessivo.

\section{Confiabilidade}

A confiabilidade está relacionada com a realização das viagens programadas dentro do horário previsto.

Dessa forma, a confiabilidade engloba a pontualidade (cumprimento dos horários) e a efetividade na realização da programação operacional.

\section{Segurança}

A item segurança compreende os acidentes envolvendo os veículos de transporte público e os atos de violência no interior dos veículos e nos locais de parada.

A violência no interior dos veículos e nos locais de parada deve ser tratada como um problema geral de segurança da comunidade.

No caso do transporte público, a segurança deve estar focada na frequiência de acidentes envolvendo os veículos de transporte coletivo.

\section{Características dos veículos}

A tecnologia e o estado de conservação dos veículos de transporte são aspectos relevantes no que se relaciona ao conforto dos usuários. 
Também a aparência do veículo (visual da parte externa e interna) influi no grau de satisfação dos usuários.

No caso dos ônibus, os principais aspectos que interferem na comodidade são: número de portas, largura do corredor, altura dos degraus das escadas e estado de conservação.

\section{Características dos locais de parada}

Com relação às características fisicas dos locais de parada, os seguintes aspectos são importantes: sinalização adequada e existência de cobertura e bancos para sentar (sobretudo nos locais de maior movimento).

\section{Sistema de informações}

O sistema de informações diz respeito à disponibilidade de folhetos com os horários e itinerários das linhas, existência de informações sobre as linhas que passam e os horários (intervalos no caso das linhas de maior freqüência) nos locais de parada, informações sobre a rede de linhas no interior dos veículos, fornecimento de informações verbais por parte dos motoristas e cobradores, posto para fornecimento de informações e recebimento de reclamações e sugestões (pessoalmente e por telefone), etc.

\section{Transbordabilidade}

A transbordabilidade diz respeito à facilidade de deslocamento dos usuários entre dois locais quaisquer da cidade. 
A transbordabilidade depende, portanto, da configuração espacial da rede de linhas, da existência ou não de integração fisica e tarifária e, também, dos tempos de espera nos transbordos.

\section{Comportamento dos operadores}

Com relação ao comportamento dos motoristas são aspectos importantes: conduzir o veículo com habilidade e cuidado, tratar os passageiros com respeito, esperar que os usuários completem as operações de embarque e desembarque antes de fechar as portas, etc.

Quanto ao cobrador valem as mesmas observações, exceto as que se relacionam com o modo de dirigir.

\section{Estado das vias}

O estado das vias diz respeito às condições da superficie de rolamento (presença de buracos, lombadas e valetas e existência ou não de pavimentação).

Também importante é a sinalização da via, para garantir segurança e conforto aos passageiros.

\subsection{PADRÕES DE QUALIDADE PARA OS USUÁRIOS}

Na tabela 3.1 encontram-se os padrões de qualidade propostos para o transporte público por ônibus por FERRAZ E TORRES (2001). 
Tabela 3.1 - Padrões de qualidade no transporte público coletivo por ônibus. Fonte: FERRAZ E TORRES (2001).

\begin{tabular}{|c|c|c|c|c|}
\hline Fatores & Parâmetros de avaliação & Bom & Regular & Ruim \\
\hline \multirow{2}{*}{ Acessibilidade } & $\begin{array}{c}\text { Distância de caminhada no } \\
\text { início e no fim da viagem (m) }\end{array}$ & $<300$ & $300-500$ & $>500$ \\
\hline & $\begin{array}{l}\text { Declividade dos percursos não } \\
\text { exagerada, passeios revestidos e } \\
\text { em bom estado e segurança na } \\
\text { travessia das ruas }\end{array}$ & $\begin{array}{l}\text { Satis- } \\
\text { fatório }\end{array}$ & $\begin{array}{l}\text { Deixa a } \\
\text { desejar }\end{array}$ & $\begin{array}{l}\text { Insatis- } \\
\text { fatório }\end{array}$ \\
\hline $\begin{array}{l}\text { Freqüência de } \\
\text { atendimento }\end{array}$ & $\begin{array}{l}\text { Intervalo entre atendimentos } \\
\text { (minutos) }\end{array}$ & $<15$ & $15-30$ & $>30$ \\
\hline Tempo de viagem & $\begin{array}{c}\text { Relação entre o tempo de } \\
\text { viagem por ônibus e por carro }\end{array}$ & $<1,5$ & $1,5-2,5$ & $>2,5$ \\
\hline Lotação & $\begin{array}{c}\text { Taxa de passageiros em pé } \\
\text { (pass } / \mathrm{m}^{2} \text { ) }\end{array}$ & $<2,5$ & $2,5-5,0$ & $>5,0$ \\
\hline Confiabilidade & $\begin{array}{c}\text { Viagens não realizadas ou } \\
\text { realizadas com adiantamento }> \\
3 \text { min e atraso }>5 \min (\%)\end{array}$ & $<1,0$ & $1,0-3,0$ & $>3,0$ \\
\hline Segurança & $\begin{array}{l}\text { Índice de acidentes } \\
\text { (acidentes/100 mil km) }\end{array}$ & $<1,0$ & $1,0-2,0$ & $>2,0$ \\
\hline \multirow[t]{3}{*}{$\begin{array}{l}\text { Características } \\
\text { dos ônibus }\end{array}$} & $\begin{array}{l}\text { Idade e estado } \\
\text { de conservação }\end{array}$ & $\begin{array}{c}\mathrm{I}<5 \text { a bom } \\
\text { estado }\end{array}$ & $\begin{array}{l}\quad 5<\mathrm{I}<10 \mathrm{a} \\
\text { bom estado }\end{array}$ & $\begin{array}{l}\text { Outras } \\
\text { situações }\end{array}$ \\
\hline & $\begin{array}{l}\text { Número de portas e } \\
\text { largura do corredor }\end{array}$ & 3 portas & $\begin{array}{c}2 \text { portas } \\
\text { corredor } \\
\text { largo }\end{array}$ & $\begin{array}{l}\text { Outras } \\
\text { situações }\end{array}$ \\
\hline & Altura dos degraus & Pequena & $\begin{array}{l}\text { Deixa a } \\
\text { desejar }\end{array}$ & Grande \\
\hline
\end{tabular}


Tabela 3.1 (continuação) - Padrões de qualidade para o transporte público por ônibus.

\begin{tabular}{|c|c|c|c|c|}
\hline Fatores & Parâmetros de avaliação & Bom & Regular & Ruim \\
\hline \multirow{3}{*}{$\begin{array}{c}\text { Características dos } \\
\text { locais de parada }\end{array}$} & Sinalização & Na maioria & $\begin{array}{l}\text { Deixa a } \\
\text { desejar }\end{array}$ & $\begin{array}{c}\text { Falta } \\
\text { em muitos }\end{array}$ \\
\hline & Cobertura & Na maioria & $\begin{array}{l}\text { Deixa a } \\
\text { desejar }\end{array}$ & $\begin{array}{c}\text { Em } \\
\text { poucos }\end{array}$ \\
\hline & Banco para sentar & Na maioria & $\begin{array}{l}\text { Deixa a } \\
\text { desejar }\end{array}$ & $\begin{array}{c}\text { Em } \\
\text { poucos }\end{array}$ \\
\hline \multirow{3}{*}{$\begin{array}{l}\text { Sistema de } \\
\text { informações }\end{array}$} & $\begin{array}{l}\text { Folhetos com itinerários } \\
\text { e horários disponíveis }\end{array}$ & $\begin{array}{l}\text { Satis- } \\
\text { fatório }\end{array}$ & $\begin{array}{l}\text { Deixa a } \\
\text { desejar }\end{array}$ & $\begin{array}{l}\text { Insatis- } \\
\text { fatório }\end{array}$ \\
\hline & $\begin{array}{c}\text { Informações adequadas } \\
\text { nas paradas }\end{array}$ & $\begin{array}{l}\text { Satis- } \\
\text { fatório }\end{array}$ & $\begin{array}{l}\text { Deixa a } \\
\text { desejar }\end{array}$ & $\begin{array}{l}\text { Insatis- } \\
\text { fatório }\end{array}$ \\
\hline & $\begin{array}{c}\text { Informações e reclamações } \\
\text { (pessoalmente ou por telefone) }\end{array}$ & $\begin{array}{l}\text { Satis- } \\
\text { fatório }\end{array}$ & $\begin{array}{l}\text { Deixa a } \\
\text { desejar }\end{array}$ & $\begin{array}{l}\text { Insatis- } \\
\text { fatório }\end{array}$ \\
\hline \multirow{3}{*}{ Transbordabilidade } & Transbordos (\%) & $<15$ & $15-30$ & $>30$ \\
\hline & Integração física & $\begin{array}{l}\text { Satis- } \\
\text { fatório }\end{array}$ & $\begin{array}{l}\text { Deixa a } \\
\text { desejar }\end{array}$ & $\begin{array}{l}\text { Insatis- } \\
\text { fatório }\end{array}$ \\
\hline & Integração tarifária & Sim & Não & Não \\
\hline \multirow{2}{*}{$\begin{array}{l}\text { Comportamento } \\
\text { dos operadores }\end{array}$} & $\begin{array}{l}\text { Motoristas dirigindo com } \\
\text { habilidade e cuidado }\end{array}$ & $\begin{array}{l}\text { Satis- } \\
\text { fatório }\end{array}$ & $\begin{array}{l}\text { Deixa a } \\
\text { desejar }\end{array}$ & $\begin{array}{l}\text { Insatis- } \\
\text { fatório }\end{array}$ \\
\hline & $\begin{array}{l}\text { Motoristas e cobradores } \\
\text { prestativos e educados }\end{array}$ & $\begin{array}{l}\text { Satis- } \\
\text { fatório }\end{array}$ & $\begin{array}{l}\text { Deixa a } \\
\text { desejar }\end{array}$ & $\begin{array}{l}\text { Insatis- } \\
\text { fatório }\end{array}$ \\
\hline $\begin{array}{c}\text { Estado } \\
\text { das vias }\end{array}$ & $\begin{array}{l}\text { Vias pavimentadas e sem } \\
\text { buracos, lombadas e valetas e } \\
\text { com sinalização adequada. }\end{array}$ & $\begin{array}{l}\text { Satis- } \\
\text { fatório }\end{array}$ & $\begin{array}{l}\text { Deixa a } \\
\text { desejar }\end{array}$ & $\begin{array}{l}\text { Insatis- } \\
\text { fatório }\end{array}$ \\
\hline
\end{tabular}




\section{O SiSTEMA ATUAL DE TRANSPORTE PÚblico URBANo DE JAÚ}

\subsection{Rede e linhas de ônibus}

A rede de transporte público da cidade de Jaú é do tipo radial, pois todas as zonas não centrais são interligadas à zona central, através de uma ou mais linhas. Dessa forma, todas as viagens com origem ou destino na área central são realizadas sem necessidade de transbordo. As viagens entre quaisquer outras zonas requerem transbordo, exceto nos casos em que as zonas de origem e destino são atendidas pela mesma linha.

O traçado das linhas de ônibus é diametral, pois todas elas conectam duas regiões opostas, passando pela área central. Os itinerários de cada uma das linhas são apresentados nos mapas de 1 a 23 no anexo 1 .

Todas as linhas são do tipo convencional, pois executam simultaneamente as funções de captação dos usuários na origem, transporte até o destino e distribuição no destino.

As principais características operacionais das linhas existentes são apresentadas nas tabelas 4.1 e 4.2 . 
Tabela 4.1 - Características das linhas de ônibus de Jaú (parte1).

\begin{tabular}{|c|c|c|c|c|}
\hline Número & Nome & $\begin{array}{c}\text { Extensão } \\
(\mathbf{K m})\end{array}$ & $\begin{array}{c}\text { Tempo } \\
\mathbf{d e} \text { ciclo } \\
(\mathbf{m i n})\end{array}$ & $\begin{array}{c}\text { Velocidade } \\
(\mathbf{k m} / \mathbf{h})\end{array}$ \\
\hline 1 & Jd. Pedro Ometto - Jd. S. José & 20 & 64 & 18.69 \\
\hline 3 & Jd. Sempre Verde - Jd. Olimpia & 21.60 & 60 & 21.60 \\
\hline 5 & Cemitério - Jd. Perdo Ometto & 15.20 & 54 & 16.89 \\
\hline 7 & Cemitério - Jd. Jorge atalla & 15,2 & 52 & 17.47 \\
\hline 9 & Jd. Jorge Atalla - Jd. São José & 19 & 60 & 19.00 \\
\hline 11 & Cemitério - Jd. Novo Horizonte & 20 & 58 & 20.62 \\
\hline 13 & V. Maria - Jd. Sempre Verde & 20.60 & 52 & 23.68 \\
\hline 15 & Jd. Carolina - cemitério & 16.20 & 52 & 18.62 \\
\hline 17 & Jd. Pedro Ometto - Jd. S. José & 18.40 & 62 & 17.86 \\
\hline 19 & Cemitério - Jd. America & 19.60 & 56 & 21.08 \\
\hline 21 & Cemitério - Jd. F. Dias & 19.60 & 60 & 19.60 \\
\hline 23 & Jd. Pedro Ometto - V. Netinho & 18 & 56 & 19.35 \\
\hline 25 & Jd. Odete - Jd. F. Dias & 19.60 & 56 & 21.08 \\
\hline 27 & Jd. Olimpia - Jd. Nova jaú & 20 & 54 & 22.20 \\
\hline 29 & Jd. Nova Jaú - Jd. America & 19.40 & 54 & 21.55 \\
\hline 31 & Jd. Sta. Helena - Jd. Olimpia & 21.6 & 56 & 23.22 \\
\hline 39 & Jd. Vil. di Roma - Jd. M. Luiza IV & 22 & 58 & 22.68 \\
\hline 51 & Jd. M. Luiza IV - Jd. N. Horizonte & 17.40 & 56 & 18.70 \\
\hline 53 & Jd. Orlando Ometto - Sta . Casa & 16.40 & 58 & 16.90 \\
\hline 55 & Jd. Padre Ag.Sani - Jd. São José & 19 & 60 & 19.00 \\
\hline 57 & Jd. M. Luiza - Vilagio di Roma & 20.9 & 64 & 19.59 \\
\hline 59 & Jd. P.A. Sani - Jd. Orlando Ometto & 22 & 60 & 22.00 \\
\hline 61 & Jd. Parati - Sta. Casa & 19 & 60 & 19.00 \\
\hline 63 & Jd. João Balan - Jd. Sanzovo & 19 & 48 & 23.75 \\
\hline
\end{tabular}


Tabela 4.2 - Características das linhas de ônibus de Jaú (parte2).

\begin{tabular}{|c|c|c|c|c|}
\hline Número & Nome & $\begin{array}{l}\text { Intervalo de } \\
\text { passagem" } \\
\text { (min) }\end{array}$ & $\begin{array}{c}\text { Número } \\
\text { De } \\
\text { Pontos }\end{array}$ & $\begin{array}{c}\text { Distância } \\
\text { média } \\
(\mathrm{m})\end{array}$ \\
\hline 1 & Jd. Pedro Ometto - Jd. S. José & $19 / 40$ & 56 & 247,58 \\
\hline 3 & Jd. Sempre Verde - Jd. Olimpia & $20 / 54$ & 85 & 222,14 \\
\hline 5 & Cemitério - Jd. Perdo Ometto & $17 / 59$ & 59 & 215,87 \\
\hline 7 & Cemitério - Jd. Jorge atalla & $21 / 40$ & 61 & 233,49 \\
\hline 9 & Jd. Jorge Atalla - Jd. São José & $09 / 47$ & 40 & 250,91 \\
\hline 11 & Cemitério - Jd. Novo Horizonte & $06 / 54$ & 80 & 254,84 \\
\hline 13 & V. Maria - Jd. Sempre Verde & $17 / 52$ & 73 & 196,48 \\
\hline 15 & Jd. Carolina - cemitério & $15 / 40$ & 52 & 298,27 \\
\hline 17 & Jd. Pedro Ometto - Jd. S. José & $19 / 40$ & 65 & 225,35 \\
\hline 19 & Cemitério - Jd. America & $12 / 57$ & 80 & 228,85 \\
\hline 21 & Cemitério - Jd. F. Dias & - & 73 & 218,08 \\
\hline 23 & Jd. Pedro Ometto - V. Netinho & $16 / 42$ & 62 & 202,24 \\
\hline 25 & Jd. Odete - Jd. F. Dias & $23 / 42$ & 75 & 240,09 \\
\hline 27 & Jd. Olimpia - Jd. Nova jaú & $20 / 45$ & 70 & 200 \\
\hline 29 & Jd. Nova Jaú - Jd. America & $16 / 57$ & 78 & 205,01 \\
\hline 31 & Jd. St ${ }^{\mathrm{a}}$. Helena - Jd. Olimpia & $15 / 47$ & 63 & 195,29 \\
\hline 39 & Jd. Vil. di Roma - Jd. M. Luiza IV & - & 65 & 338,46 \\
\hline 51 & Jd. M. Luiza IV - Jd. N. Horizonte & $18 / 48$ & 64 & 193,07 \\
\hline 53 & Jd. Orlando Ometto - St ${ }^{\mathrm{a}}$. Casa & $10 / 50$ & 62 & 201,03 \\
\hline 55 & Jd. Padre Ag.Sani - Jd. São José & $12 / 51$ & 65 & 351 \\
\hline 57 & Jd. M. Luiza - Vilagio di Roma & $18 / 42$ & 94 & 191,05 \\
\hline 59 & Jd. P.A. Sani - Jd. Orlando Ometto & $19 / 43$ & 74 & 224,47 \\
\hline 61 & Jd. Parati - St . Casa & $9 / 57$ & 70 & 199,03 \\
\hline 63 & Jd. João Ballan - Jd. Sanzovo & $26 / 32$ & 47 & 225,75 \\
\hline
\end{tabular}

* intervalo entre atendimentos no picos / intervalo entre atendimentos fora dos picos.

\subsection{Pontos de parada}

Na cidade de Jaú existem 1.613 pontos de parada de ônibus urbano.

Na sua grande maioria, os pontos de parada não possuem sinalização adequada e nem abrigos. 


\subsection{Terminal central de integração física das linhas}

A cidade conta com um terminal central de integração física na área central, próximo da Estação Rodoviária, conforme mostrado nos mapas das linhas no anexo 1.

\subsection{Empresa operadora}

A operadora do sistema de transporte público urbano de Jaú é a "Empresa de Auto Ônibus Macacari Ltda", com administração familiar, e que também atua nas áreas de fretamento e turismo.

\subsection{Informações gerais do sistema}

- Frota total: 28 veículos, sendo 23 veículos da frota operante e 5 veículos reservas.

- Salário mensal médio do motorista $=\mathrm{R} \$ 1.100,85$.

- Salário mensal médio do cobrador $=\mathrm{R} \$ 812,82$

- Salário mensal médio de fiscal/despachante $=\mathrm{R} \$ 1.632,14$

- Salário mensal médio de mecânico $=\mathrm{R} \$ 2.536,09$

- Número mensal de passageiros $=391.285$ passageiros, sendo: 29.500 passageiros com desconto de $50 \%$ (sistema de passe escolar) e 361.745 passageiros sem desconto.

- Quilometragem mensal percorrida pela empresa $=204.540 \mathrm{~km} / \mathrm{mês}$.

- Número mensal equivalente de passageiros $=376.515$ pass $/ \mathrm{mês}$

- Número mensal de passageiros por veículo $=18.826$ pass/veíc

- Percurso mensal por veículo $=8.522 .50 \mathrm{~km} / \mathrm{veíc}$

- Custo operacional $=\mathrm{R} \$ 1,9406 / \mathrm{km}$.

- Índice de passageiros por quilômetro $(\mathrm{IPK})=1,8408$ pass/veíc

- $\quad$ Tarifa $=\mathrm{R} \$ 0,90$ 


\subsection{Controle da operação}

O controle da operação do transporte público urbano de Jaú é feito através de fiscais. Quando necessário, as comunicações com a garagem são feitas por telefone comum.

\subsection{Pagamento da passagem e controle de acesso}

O pagamento de passagem é feito através do uso do passe de plástico ou realizado no momento da viagem, com o pagamento feito ao cobrador.

O controle de acesso é feito com a atuação e fiscalização do cobrador e registro em catraca.

\subsection{Sistema de informação aos usuários}

As informações relativas à linha são veiculadas na parte superior frontal dos ônibus, como é comum.

Outras informações, como horários e também itinerários, podem ser obtidas através do serviço telefônico que a empresa disponibiliza aos usuários.

Não há disponibilidade de folhetos com informações dos trajetos e horários das linhas.

\subsection{Outras informações relevantes}

Outras informações relevantes sobre o sistema de transporte coletivo de Jaú são a seguir relacionadas. 


\subsubsection{Tempo de viagem}

Foram realizadas pesquisas de campo em todas as linhas nos pontos críticos em termos de tempo de viagem - até ou desde a área central - e os resultados comparados com os tempos gastos por automóvel seguindo a rota mais curta.

Os resultados obtidos expressos na forma de relação entre o tempo de viagem por ônibus e por carro, considerando todas as linhas se encontram na faixa entre 1,9 e 2,5 .

\subsubsection{Segurança}

Não há registros disponíveis.

\subsubsection{Confiabilidade}

Não há registros disponíveis com relação à porcentagem de viagens programadas não realizadas ou realizadas com atrasos significativos.

\subsubsection{Lotação}

Observações visuais realizadas nos trechos críticos (de maior lotação) mostram lotações máximas menores que 5,0 passageiros em pé por metro quadrado, nos períodos de pico e normais.

\subsubsection{Características dos veículos da frota}

A composição etária da frota é a seguinte: número de veículos de 0 a 1 ano $=05$, de 3 a 4 anos $=03$, de 4 a 5 anos $=02$, de 5 a 6 anos $=02$, de 6 a 7 anos $=02$, com mais de 7 anos $=19$. 
Todos os veículos têm duas portas, corredor estreito (são duas fileiras de assentos dos dois lados) e degraus altos, com exceção de dois (02) veículos que têm 3 portas.

O estado geral dos veículos pode ser considerado satisfatório, mesmo no caso dos veículos mais velhos.

\subsubsection{Integração}

O sistema conta com um terminal central aberto para integração física das linhas, com instalações bastante precárias.

Não há integração tarifária.

\subsubsection{Comportamento dos operadores}

Baseado em observações realizadas por pesquisadores, pode-se concluir que o comportamento dos motoristas e cobradores é satisfatório.

\subsubsection{Estado das vias}

Levantamento efetuado por pesquisadores permite concluir que todas as vias por onde passam os ônibus são pavimentadas e em bom estado de conservação. Observase, no entanto, a presença de algumas valetas e lombadas bastante pronunciadas.

Contudo, na região periférica a sinalização de trânsito é bastante precária ou inexistente. 


\section{AVAliaÇão DA QUALIDADE DO \\ Transporte Público Urbano EM JaÚ}

\subsection{Avaliação técnica}

A avaliação técnica da qualidade foi realizada com base nos padrões definidos na tabela 3.1, para cada um dos parâmetros individualmente, conforme segue.

\subsubsection{Acessibilidade à rede de linhas}

Para se analisar a acessibilidade à rede de transporte público foi, inicialmente, feito um mapeamento da ocupação e uso do solo na cidade por quadra, através de levantamento de campo utilizando automóvel. O resultado desse trabalho é mostrado no mapa do anexo 9.

Nesse mapa encontram-se identificadas as áreas habitadas e os principais pólos de atração de viagens, bem como as áreas não habitáveis por razões institucionais, geográficas, topográficas, etc. e as áreas situadas próximas à mancha urbana, ou no interior da mesma, ainda não loteadas.

As áreas loteadas foram classificadas em três categorias:

- Bem adensadas: $70 \%$ a $100 \%$ dos lotes ocupados ( média $=85 \%$ ).

- Medianamente adensadas: $40 \%$ a $70 \%$ dos lotes ocupados (média $=55 \%$ ).

- Pouco adensadas: $0 \%$ (início de adensamento) a $40 \%$ dos lotes ocupados (média $=20 \%$ ).

Na tabela 5.1 encontram-se relacionados o número de quadras em cada uma das categorias de adensamento consideradas. 
Tabela 5.1 - Caracterização do tipo de adensamento por quadra em Jaú.

\begin{tabular}{|c|c|c|}
\hline $\begin{array}{c}\text { Tipo de } \\
\text { Adensamento }\end{array}$ & $\begin{array}{c}\text { Número de } \\
\text { Quadras }\end{array}$ & $\begin{array}{c}\text { Número médio de habitantes } \\
\text { por quadra }\end{array}$ \\
\hline Bem adensada & 637 & 151,61 \\
\hline Medianamente adensada & 95 & 98,10 \\
\hline Pouco adensada & 174 & 35,67 \\
\hline
\end{tabular}

Denominando de $\mathrm{N}$ o número médio de habitantes nas quadras totalmente ocupadas da cidade, têm-se as seguintes relações:

- Número médio de habitantes nas quadras das regiões bem adensadas:

$\mathrm{N}_{\mathrm{BA}}=0,85 \mathrm{~N}$.

- Número médio de habitantes nas quadras das regiões medianamente adensadas:

$\mathrm{N}_{\mathrm{BA}}=0,55 \mathrm{~N}$.

- Número médio de habitantes nas quadras das regiões pouco adensadas:

$\mathrm{N}_{\mathrm{BA}}=0,20 \mathrm{~N}$.

A seguinte relação matemática pode ser utilizada para estimar o número médio de habitantes nas quadras correspondentes às diversas categorias de adensamento:

$$
P=N_{B A} \times Q_{B A}+N_{M A} \times Q_{M A}+N_{P A} \times Q_{P A}
$$

Onde, $\mathrm{P}$ : população da cidade, $\mathrm{N}_{\mathrm{BA}}$ : número de habitantes por quadra nas regiões bem adensadas, $\mathrm{N}_{\mathrm{MA}}$ : número de habitantes por quadra nas regiões medianamente adensadas, $\mathrm{N}_{\mathrm{PA}}$ : número de habitantes por quadra nas regiões pouco adensadas, $\mathrm{Q}_{\mathrm{BA}}$ : número de quadras bem adensadas, $\mathrm{Q}_{\mathrm{MA}}$ : número de quadras medianamente adensadas e $\mathrm{Q}_{\mathrm{BA}}$ : número de quadras pouco adensadas.

Considerando ser de aproximadamente 112.000 habitantes (IBGE, 2000) a população da cidade de Jaú e substituindo na equação os resultados obtidos anteriormente, obtém-se:

$$
112.000=637 \times 0,85 \mathrm{~N}+94 \times 0,55 \mathrm{~N}+174 \times 0,20 \mathrm{~N}
$$

Daí resulta: $\mathrm{N}=178,36$ e, em conseqüência, $\mathrm{N}_{\mathrm{BA}}=151,61, \mathrm{~N}_{\mathrm{MA}}=98,10$ e $\mathrm{N}_{\mathrm{PA}}=$ 35,67 . Esses valores encontram-se reproduzidos na tabela 5.1 
A rede de linhas de transporte público por ônibus na cidade de Jaú é mostrada na pag 78 anexo 1.

O confronto do mapa de ocupação do solo e o mapa da rede de linhas permite visualizar a acessibilidade das várias quadras ao sistema de transporte coletivo, conforme mostrado no mapa do anexo 9.

Para se analisar a qualidade do serviço de transporte público no que se refere à acessibilidade, é necessário considerar os dois limites de padrões colocados na tabela 3.1: 300 e 500 metros de distância de caminhada. Admitindo esses valores como correspondendo a distâncias perpendiculares à rede de 200 e 333 metros respectivamente, obtém-se a carta de acessibilidade apresentada no mapa do anexo 10. Nesse mapa é possível visualizar as áreas com acessibilidade consideradas boa, regular e ruim, de acordo com os padrões definidos na tabela 3.1.

Com base no mapa do anexo 10 e no número de habitantes por quadra conforme o padrão de adensamento, é possível obter os valores relacionados na tabela 5.2.

Tabela 5.2 - Dados sobre a acessibilidade à rede de transporte coletivo em Jaú.

\begin{tabular}{|l|l|l|l|l|}
\hline $\begin{array}{l}\text { Padrão } \\
\text { de } \\
\text { acessibilidade }\end{array}$ & $\begin{array}{l}\text { Número de } \\
\text { quadras bem } \\
\text { adensadas }\end{array}$ & $\begin{array}{l}\text { Número quadras } \\
\text { medianamente } \\
\text { adensadas }\end{array}$ & $\begin{array}{l}\text { Número de } \\
\text { quadras pouco } \\
\text { adensadas }\end{array}$ & $\begin{array}{l}\text { Habitantes/ } \\
\text { Porcentagem }\end{array}$ \\
\hline Bom & 616.9 & 81.5 & 127.10 & $106.057,0 / 94.6 \%$ \\
\hline Regular & 19.1 & 12.75 & 31.65 & $5.275,4 / 4.706 \%$ \\
\hline Ruim & 1 & 0.75 & 15.25 & $769,1 / 0.686 \%$ \\
\hline Total & 637 & 95 & 174 & $112.101,5 / 100 \%$ \\
\hline
\end{tabular}

Os números mostram que a acessibilidade à rede de transporte público é muito boa, pois 94.6 pontos percentuais (94.6\%), da população da cidade de Jaú tem boa acessibilidade a rede de transporte público, e menos de 1 ponto percentual $(0.686 \%)$ dessa mesma população tem acessibilidade ruim.

Também é possível aferir, pela análise da tabela 5.2, que a rede de transporte coletivo está, na grande maioria, associada às regiões de maior densidade populacional. 
Um fato interessante observado na carta de acessibilidade é a inexistência de linhas regulares de ônibus para o atendimento dos distritos industriais. Isso ocorre em razão das empresas localizadas nesses locais contratarem transporte fretado para os seus funcionários.

\subsubsection{Freqüência}

A comparação dos valores apresentados no capítulo 4 com os padrões de qualidade apresentados na tabela 3.1 mostra que a qualidade no tocante ao intervalo entre atendimento é ruim em todas as linhas nos períodos normais (de menor movimento). Nos períodos de pico, a qualidade é boa em 3 linhas e regular nas demais.

\subsubsection{Tempo de viagem}

Conforme as informações contidas no capítulo 4 e os padrões de qualidade estabelecidos na tabela 3.1 a qualidade do serviço no tocante ao tempo de viagem pode ser considerada regular.

\subsubsection{Lotação}

De acordo com as informações apresentadas no capítulo 4 e à luz do quadro de referência de qualidade da tabela 3.1 , pode-se dizer que de maneira genérica a qualidade do serviço com referência à lotação é regular.

\subsubsection{Confiabilidade}

Não há informações disponíveis para avaliação da qualidade relativa a este parâmetro.

\subsubsection{Segurança}

Não há informações disponíveis para avaliação da qualidade sob o aspecto da segurança. 


\subsubsection{Características dos veículos}

Com base nas informações contidas no capítulo 5 em comparação com os padrões de referência citados na tabela 3.1, a qualidade do serviço no tocante a este parâmetro pode ser considerada entre regular e ruim.

\subsubsection{Características dos locais de parada}

Baseado nas informações contidas no capítulo 5, pode-se afirmar, de acordo com os padrões estabelecidos na tabela 3.1, que a qualidade do serviço no tocante a este parâmetro pode ser considerada ruim.

\subsubsection{Sistema de informações}

À luz das informações contidas no capítulo 5 e com base nos padrões estabelecidos na tabela 3.1, pode-se dizer que a qualidade do serviço no tocante a este parâmetro é ruim.

\subsubsection{Transbordabilidade}

Baseado nas informações do capítulo 5 e à luz dos padrões de qualidade definidos na tabela 3.1, pode-se afirmar que a qualidade do serviço no tocante a este parâmetro é ruim.

\subsubsection{Comportamento dos operadores}

Com base nas informações do capítulo 5 e nos padrões de qualidade estabelecidos na tabela 3.1, a qualidade do serviço no tocante a este parâmetro pode ser considerada boa.

\subsubsection{Estado das vias}

As informações contidas no capítulo 5 e os padrões de qualidade definidos na tabela 3.1 permitem concluir que a qualidade do serviço no tocante a este parâmetro pode ser considerada regular. 
A tabela 5.2.1 mostra um resumo dos resultados da avaliação técnica.

Tabela 5.2,1 - Resumo da avaliação técnica da qualidade do transporte coletivo em Jaú.

\begin{tabular}{|l|l|l|l|}
\hline \multicolumn{1}{|c|}{ Parâmetro / Qualidade } & Boa & Regular & Ruim \\
\hline Acessibilidade & X & & \\
\hline Freqüência & X & & X \\
\hline Tempo de viagem & & X & \\
\hline Lotação & & & \\
\hline Confiabilidade* & & & \\
\hline Segurança* & & & $\mathbf{X}$ \\
\hline Características dos ônibus & & & $\mathbf{X}$ \\
\hline Características dos locais de parada & & & $\mathbf{X}$ \\
\hline Sistema de informação & & & $\mathbf{X}$ \\
\hline Transbordabilidade & & & \\
\hline Comportamento dos operadores & $\mathbf{X}$ & & \\
\hline Estado das vias & & & \\
\hline
\end{tabular}

* Não há informações disponiveis para avaliação.

\subsection{Avaliação baseada em pesquisas de opinião}

Foram realizadas pesquisas de opinião por amostragem com usuários, pessoas da comunidade e membros do governo. A seguir são relatados a metodologia e os resultados dessas pesquisas.

\subsubsection{Pesquisa de opinião com usuários}


Foram duas as pesquisas de opinião com os usuários. Na primeira, o usuário deveria atribuir conceitos para alguns itens existentes no transporte público de Jaú. Na segunda, classificar algumas melhorias de acordo com a sua importância.

Em ambas pesquisas foram entrevistados os mesmos 239 usuários.

O questionário utilizado na primeira pesquisa encontra-se no anexo 6 e os resultados obtidos na tabela 5.3 e nas figuras de 1 a 17 do anexo 2

Tabela 5.3 - Resultado da primeira pesquisa de opinião com usuários.

\begin{tabular}{|l|c|c|c|c|c|}
\hline $\begin{array}{l}\text { Como você classifica os seguintes } \\
\text { relacionados à qualidade de transporte por }\end{array}$ & $\begin{array}{c}\text { Muit } \\
\text { bo }\end{array}$ & Bo & Regula Rui & $\begin{array}{l}\text { Muit } \\
\text { rui }\end{array}$ \\
\hline 1- Distância percorrida à pé para usar os & 4,18 & 68,20 & 8,79 & 15,90 & 2,51 \\
\hline 2- Intervalo entre a passagem dos & 1,26 & 44,77 & 16,32 & 30,54 & 6,69 \\
\hline 3- Tempo de viagem dentro do & 1,67 & 64,02 & 15,9 & 14,64 & 3,77 \\
\hline 4- Cumprimento dos & 4,18 & 46,44 & 21,76 & 22,59 & 4,60 \\
\hline 5- Lotação (número de pessoas) dentro dos & 0,42 & 39,33 & 26,78 & 25,52 & 6,69 \\
\hline 6- Aparência dos & 2,51 & 59,41 & 25,94 & 10,04 & 1,26 \\
\hline 7- Altura dos degraus do & 1,26 & 33,89 & 16,32 & 38,91 & 9,21 \\
\hline 8- Conservação e limpeza dos & 3,77 & 61,51 & 17,57 & 13,39 & 2,93 \\
\hline 9- Sinalização dos pontos de & 0,84 & 20,08 & 14,23 & 47,70 & 17,15 \\
\hline 10- Abrigo nos pontos de & 0,42 & 11,72 & 4,60 & 55,65 & 27,62 \\
\hline 11- Banco nos pontos de & 0 & 15,06 & 4,18 & 52,30 & 27,62 \\
\hline 12- Modo como os motoristas & 2,09 & 62,34 & 23,01 & 10,04 & 1,67 \\
\hline $\begin{array}{l}\text { 13- Educação dos motoristas e cobradores para } \\
\text { usuários. }\end{array}$ & 5,86 & 66,53 & 17,15 & 7,53 & 2,51 \\
\hline 14- Estado das vias por onde passam os & 2,09 & 31,8 & 31,38 & 23,85 & 10,46 \\
\hline $\begin{array}{l}\text { 15- Aparência do terminal localizado junto à } \\
\text { rodoviária. }\end{array}$ & 0,42 & 10,88 & 22,18 & 38,49 & 27,62 \\
\hline 16- Valor da & 1,67 & 28,87 & 25,94 & 35,15 & 7,53 \\
\hline 17- Avaliação global do transporte por & 3,35 & 40,59 & 45,19 & 10,46 & 0,00 \\
\hline
\end{tabular}

O questionário utilizado na segunda pesquisa encontra-se no anexo 6 e os resultados obtidos na tabela 5.4 e nas figuras de 1 a 9 no anexo 3 . 
Tabela 5.4 - Resultado da segunda pesquisa de opinião com usuários do TPU

\begin{tabular}{|l|l|l|l}
\hline $\begin{array}{l}\text { Como você classifica os seguintes aspectos no } \\
\text { transporte por ônibus? }\end{array}$ & $\begin{array}{l}\text { Muito } \\
\text { importante }\end{array}$ & Importante & $\begin{array}{l}\text { Pouco } \\
\text { importante }\end{array}$ \\
\hline 1- Ônibus com 3 portas. & 33,05 & 37,66 & 27,62 \\
\hline 2-Ônibus com degraus baixos. & 51,46 & 42,26 & 4,60 \\
\hline 3- Ônibus com melhor aparência. & 35,15 & 49,37 & 13,81 \\
\hline 4- Abrigo nas paradas de ônibus. & 80,33 & 15,90 & 1,67 \\
\hline 5- Bancos nas paradas de ônibus. & 81,59 & 15,06 & 1,67 \\
\hline $\begin{array}{l}\text { 6- Poder ir de um lugar a qualquer outro da cidade } \\
\text { pagando uma única vez. }\end{array}$ & 88,28 & 6,69 & 3,35 \\
\hline $\begin{array}{l}\text { 7- Trocar de ônibus quando necessário num local } \\
\text { coberto e com bancos. }\end{array}$ & 77,41 & 18,83 & 2,09 \\
\hline 8- Folheto com os horários. & 44,77 & 44,77 & 8,37 \\
\hline
\end{tabular}

Com base nessas pesquisas pode-se inferir as seguintes conclusões:

Os pontos considerados positivos pelos usuários são: distância de caminhada, tempo de viagem, cumprimento dos horários, aparência , conservação e limpeza dos ônibus e comportamento dos motoristas e cobradores.

Os pontos considerados negativos são: falta de sinalização dos pontos de parada, inexistência de abrigos e bancos nos pontos de parada, escadas dos ônibus com degraus muito altos e aparência ruim do terminal atual de integração física.

Numa avaliação global, o transporte coletivo por ônibus na cidade de Jaú é considerado regular sob o ponto de vista dos usuários

\subsubsection{Pesquisa de opinião com pessoas da comunidade}

A pesquisa de opinião com membros da comunidade foi feita através de um questionário, onde os entrevistados deveriam categorizar os principais fatores referentes à qualidade do transporte público da cidade.

A pesquisa foi aplicada a 199 pessoas. O questionário utilizado encontra-se no ANEXO 7 e os resultados obtidos na tabela 5.5 e nas figuras de 1 a 9 do ANEXO 4. 
Tabela 5.5 - Resultado de pesquisa de opinião com a comunidade

\begin{tabular}{|l|c|c|c|c|c|}
\hline $\begin{array}{l}\text { Como você classifica os seguintes aspectos } \\
\text { no transporte por ônibus? }\end{array}$ & $\begin{array}{c}\text { Muito } \\
\text { bom }\end{array}$ & Bom & Regular & Ruim & $\begin{array}{c}\text { Muito } \\
\text { ruim }\end{array}$ \\
\hline 1-Aparência dos ônibus & 2,51 & 63,82 & 24,62 & 7,54 & 1,51 \\
\hline 2- Emissão de fumaça & 1,01 & 28,64 & 34,67 & 28,64 & 7,04 \\
\hline 3- Barulho dos ônibus & 1,51 & 37,69 & 26,13 & 28,64 & 6,03 \\
\hline 4-Aparência das paradas de ônibus & 0 & 8,54 & 19,10 & 54,27 & 18,09 \\
\hline - Sinalização das paradas de ônibus & 0 & 21,61 & 15,08 & 48,24 & 15,08 \\
\hline $\begin{array}{l}\text { 6- Aparência do terminal localizado junto à } \\
\text { rodoviária }\end{array}$ & 0,5 & 14,07 & 22,61 & 36,68 & 25,63 \\
\hline $\begin{array}{l}\text { 7- Comportamento dos motoristas dos ônibus no } \\
\text { trânsito }\end{array}$ & 1,51 & 55,28 & 27,14 & 12,06 & 4,02 \\
\hline 8- Prejuízo dos ônibus no trânsito & 2,01 & 60,30 & 26,13 & 9,05 & 2,01 \\
\hline 9-Avaliação global do transporte por ônibus & 4,02 & 39,70 & 44,22 & 8,54 & 3,52 \\
\hline
\end{tabular}

A análise dos resultados obtidos permite inferir as seguintes principais conclusões:

Os pontos considerados positivos pelas pessoas da comunidade são aparência dos ônibus, comportamento dos motoristas dos ônibus no trânsito, e pouco prejuízo do ônibus no trânsito.

Os pontos considerados negativos são Emissão de fumaça, barulho dos ônibus, aparência e sinalização das paradas de ônibus, aparência do terminal de integração física localizado junto a rodoviária.

Numa avaliação global, o transporte coletivo por ônibus na cidade de Jaú é considerado regular por parte da comunidade.

\subsubsection{Pesquisa de opinião com membros do governo municipal}

A pesquisa de opinião com membros do governo foi aplicada a 46 pessoas. $\mathrm{O}$ questionário foi o mesmo utilizado na pesquisa com pessoas da comunidade.

O questionário utilizado encontra-se no anexo 8 e os resultados obtidos na tabela 5.6 nas figuras de 1 a 9 do anexo 5 .

Os resultados obtidos encontram-se na tabela 5.6 e nas figuras ..... em anexo.

Tabela 5.6 - Resultado de pesquisa de opinião com o governo 


\begin{tabular}{|l|c|c|c|c|c|}
\hline $\begin{array}{l}\text { Como você classifica os seguintes } \\
\text { aspectos no transporte por ônibus? }\end{array}$ & $\begin{array}{c}\text { Muito } \\
\text { bom }\end{array}$ & Bom & Regular & Ruim & $\begin{array}{c}\text { Muito } \\
\text { ruim }\end{array}$ \\
\hline 1 - Aparência dos ônibus & 8,70 & 52,17 & 32,61 & 4,35 & 2,17 \\
\hline 2- Emissão de fumaça & 2,17 & 13,04 & 47,83 & 26,09 & 10,87 \\
\hline 3 - Barulho dos ônibus & 4,35 & 30,43 & 34,78 & 21,74 & 10,87 \\
\hline 4-Aparência das paradas de ônibus & 4,35 & 6,52 & 36,96 & 39,13 & 19,57 \\
\hline 5 - Sinalização das paradas de ônibus & 2,17 & 13,04 & 28,26 & 36,96 & 23,91 \\
\hline $\begin{array}{l}\text { 6 - Aparência do terminal localizado junto à } \\
\text { rodoviária }\end{array}$ & 0 & 6,52 & 23,91 & 39,13 & 32,61 \\
\hline $\begin{array}{l}\text { 7 - Comportamento dos motoristas dos } \\
\text { ônibus no trânsito }\end{array}$ & 4,35 & 28,26 & 36,96 & 19,57 & 10,87 \\
\hline 8 - Prejuízo dos ônibus no trânsito & 0 & 2,17 & 56,52 & 39,13 & 2,17 \\
\hline $\begin{array}{l}\text { 9 - Avaliação global do transporte por } \\
\text { ônibus }\end{array}$ & 2,17 & 21,74 & 52,17 & 21,74 & 2,17 \\
\hline \multicolumn{7}{|l|}{} \\
\hline
\end{tabular}

A análise dos resultados obtidos permite inferir as seguintes principais conclusões:

Os pontos considerados positivos pelos membros do governo da cidade de Jaú são aparência dos ônibus, barulho dos ônibus, comportamento dos motoristas dos ônibus no trânsito e prejuízo dos ônibus no trânsito.

Os pontos considerados negativos são emissão de fumaça, aparência e sinalização dos pontos de parada de ônibus e aparência do terminal localizado junto a rodoviária.

Numa avaliação global, o transporte coletivo por ônibus na cidade de Jaú é considerado regular por parte dos membros do governo municipal. 
6. Propostas para a Melhoria da Qualidade do Transporte PÚBLICO URBANO EM JAÚ

O diagnóstico acerca da qualidade do serviço dos ônibus urbanos em Jaú realizado no capítulo 5, fornece uma visão ampla da situação do transporte coletivo na cidade, permitindo a definição de diretrizes em nível estratégico para a melhoria da qualidade do transporte. Essas diretrizes são colocadas a seguir.

O desenho da rede de linhas deve ser readequado visando melhorar ainda mais a acessibilidade ao sistema em termos de distância de caminhada. Também para eliminar as superposições de itinerários que impedem o emprego de intervalos de atendimento menores.

Para melhorar a confiabilidade do sistema é importante melhorar o controle da operação através da colocação de rádios de comunicação nos ônibus e a implementação de uma central de controle operacional.

A renovação da frota com a aquisição de ônibus com "design" moderno e tecnologia mais apropriada (3 portas, degraus baixos, corredores largos, etc) também é vital para a melhoria do sistema.

Todos os pontos de parada devem ser dotados de sinalização adequada. Os pontos de maior movimento devem ser dotados de abrigos e bancos para sentar.

Com relação ao sistema de informação aos usuários, as seguintes ações são importantes: colocação do número e do nome das linhas e horários nos pontos de parada, distribuição gratuita de folhetos com os horários e itinerários das linhas e manutenção da central de informações por telefone. 
As características da cidade sugerem a implementação de um novo terminal de integração física das linhas, e que também seja fechado para permitir a integração tarifária. O local mais indicado para este terminal é a parte detrás da Estação Rodoviária da cidade. Também neste local seria interessante implementar o terminal de ônibus regional, integrando, dessa forma, o transporte urbano com o transporte suburbano (regional) e o transporte interurbano.

Na figura 6.1 é apresentado como sugestão um croquis do terminal urbano e regional anexo ao terminal interurbano da cidade.

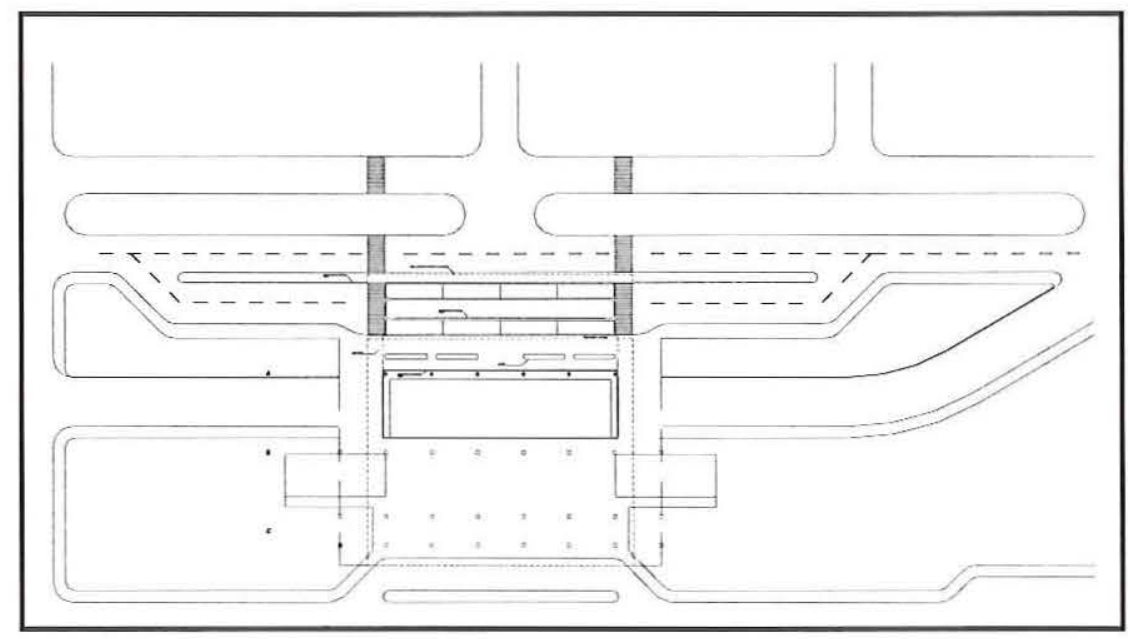

Na figura 6.2 sugestão sobre o sistema de trânsito nas vizinhanças do multi-terminal. 


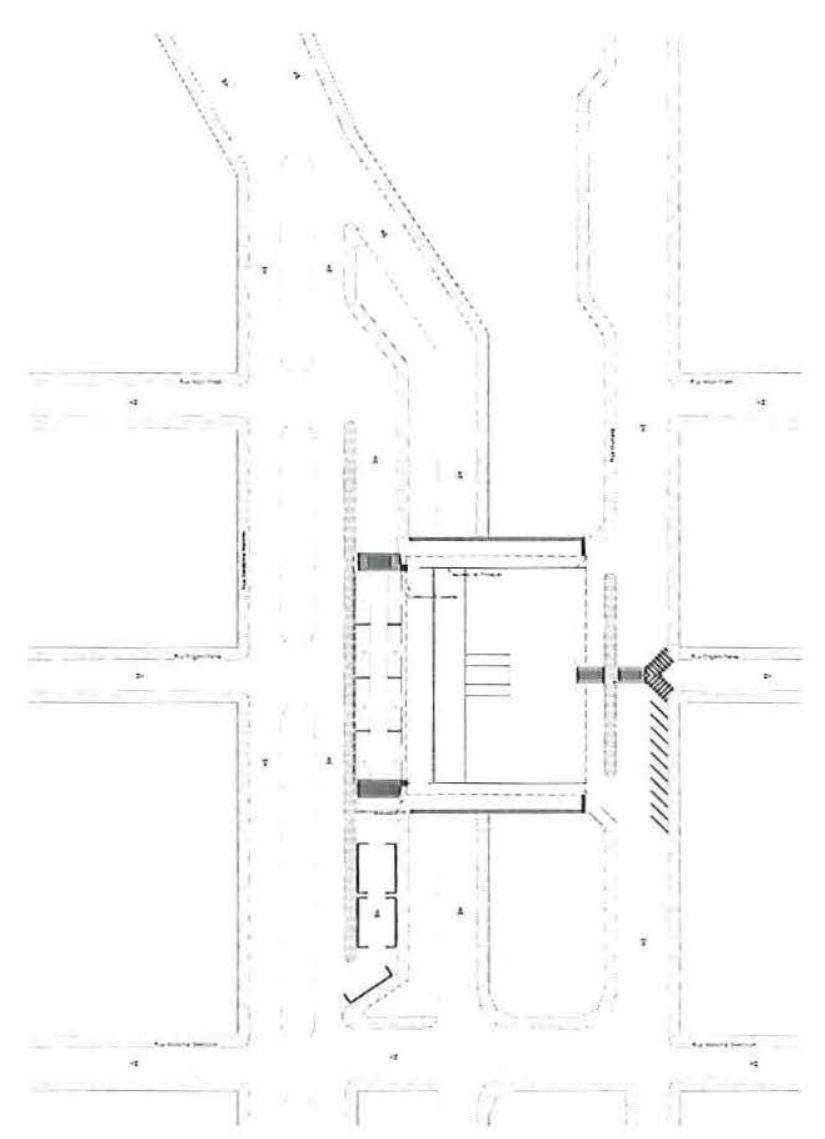

Figura 6.1 - Sugestão de reestruturação viária

Figura 6.2 - Sugestão de readequação arquitetônica.

Apesar do resultado positivo obtido no diagnóstico, é importante a implementação de programas de capacitação periódica de motoristas e cobradores, devido à grande importância dos mesmos nos aspectos segurança e comodidade dos usuários.

No tocante ao parâmetro estado das vias, é importante suavizar as valetas e as lombadas mais pronunciadas localizadas nas vias por onde circulam os ônibus, manter as vias em bom estado de conservação e sinalizá-las adequadamente. 


\section{CONSIDERAÇÕES FINAIS}

Um sistema de transporte urbano adequado é fator fundamental para o desenvolvimento econômico e social dos aglomerados humanos. A qualidade e a eficiência do sistema de transporte urbano interferem diretamente na qualidade de vida dos habitantes da cidade.

Dentre os vários modos de transporte urbano de passageiros, o mais importante é, sem dúvida, o transporte público coletivo. Primeiro, por ser o único modo de transporte motorizado acessível a população de baixa renda. Segundo, por suas inúmeras vantagens como alternativa ao uso do automóvel.

Ao transportar muitos passageiros juntos no mesmo veículo, o transporte coletivo apresenta um custo unitário baixo, atendendo, assim, as necessidades de deslocamento das pessoas de menor poder aquisitivo por motivo de trabalho, estudo, lazer, compras, etc.

Além de promover o transporte da população de baixa renda, o transporte coletivo também proporciona mobilidade às pessoas que não podem ou não desejam dirigir pelos mais variados motivos. Isso confere a esse modo de transporte um caráter democrático.

Nas grandes cidades, o transporte coletivo é de fundamental importância como alternativa ao uso do automóvel, visando a melhoria da qualidade de vida da população, uma vez que atua no sentido de reduzir a poluição atmosférica, os congestionamentos, os acidentes, o consumo de energia, etc. 
O transporte público coletivo também constitui um fator determinante na ordenação e estruturação da ocupação e uso do solo nas grandes cidades, pois favorece o adensamento populacional e a concentração de comércio e serviços em locais adequados.

Dessa forma, a melhoria do sistema de transporte público coletivo de uma cidade reverte diretamente na melhoria da qualidade de vida da população de menor poder aquisitivo, que é usuária cativa desse modo.

Nas grandes cidades a melhoria da qualidade e da eficiência do transporte público é vital para a redução do número de viagens por automóvel. Um transporte público com melhor qualidade e eficiência acaba por atrair usuários do transporte individual.

Assim, o presente trabalho, que teve como objetivo fazer um diagnóstico da situação atual do sistema de transporte coletivo em Jaú e propor ações para a melhoria desse modo de transporte na cidade, reveste-se de grande relevância.

A seguir é apresentada uma síntese do diagnóstico acerca da qualidade do transporte coletivo da cidade de Jaú, elaborado com base na comparação das características do sistema existente com padrões de qualidade considerados satisfatórios no meio técnico, pesquisa com usuários, pesquisa com pessoas da comunidade e pesquisa com membros do governo municipal.

Apresentam boa qualidade os seguintes parâmetros relativos ao transporte público coletivo urbano de Jaú: acessibilidade à rede de linhas e comportamento dos operadores.

São de qualidade regular os parâmetros: tempo de viagem, frequiência nos períodos de pico, lotação e estado das vias.

Têm qualidade insatisfatória os seguintes parâmetros: freqüência nos períodos normais, características dos veículos, características dos pontos de parada, sistema de informação aos usuários e transbordabilidade. 
No tocante aos parâmetros segurança e confiabilidade não há informações para se proceder a avaliação da qualidade.

De maneira geral, a qualidade do sistema de transporte público coletivo da cidade de Jaú pode ser classificado como regular.

Com base no diagnóstico elaborado a partir das avaliações, foram definidas as diretrizes em nível estratégico para a melhoria da qualidade do transporte. Segue uma síntese dessas diretrizes.

O desenho da rede de linhas deve ser readequado visando melhorar ainda mais a acessibilidade ao sistema em termos de distância de caminhada. Também para eliminar as superposições de itinerários que impedem o emprego de intervalos de atendimento menores.

Para melhorar a confiabilidade do sistema é importante melhorar o controle da operação através da colocação de rádios de comunicação nos ônibus e a implementação de uma central de controle operacional.

A renovação da frota com a aquisição de ônibus com "design" moderno e tecnologia mais apropriada ( 3 portas, degraus baixos, corredores largos, etc) também é vital para a melhoria do sistema.

Todos os pontos de parada devem ser dotados de sinalização adequada. Os pontos de maior movimento devem ser dotados de abrigos e bancos para sentar.

Com relação ao sistema de informação aos usuários as seguintes ações são importantes: colocação do número e do nome das linhas e horários nos pontos de parada, distribuição gratuita de folhetos com os horários e itinerários das linhas e manutenção da central de informações por telefone. 
As características da cidade sugerem a implementação de um novo terminal de integração física das linhas, e que também seja fechado para permitir a integração tarifária. O local mais indicado para este terminal é a parte de trás superior da Estação Rodoviária da cidade. Também neste local seria interessante implementar o terminal de ônibus regional, integrando, dessa forma, o transporte urbano com o transporte suburbano (regional) e o transporte interurbano.

No tocante ao item estado das vias é importante suavizar as valetas e as lombadas mais pronunciadas localizadas nas vias por onde circulam os ônibus, manter essas vias em bom estado de conservação e sinalizá-las adequadamente.

Com a definição, neste trabalho, das diretrizes em nível estratégico, foi dado um importante passo no sentido de promover a melhoria do sistema de transporte público coletivo da cidade de Jaú. A definição de planos em nível tático e operacional constituem as próximas etapas a serem trilhadas visando à concretização do projeto de dotar Jaú de um sistema de transporte público coletivo modelo para as outras cidades de porte similar do país. 


\section{Anexo-1}

Mapa das linhas de ônibus, com identificação de-

a- Trajetória

b- Terminal Rodoviário

c- localização de pontos de parada

Totall de linhas -24 
Linha 01 - Jd. Pedro Ometto x Jd. São José

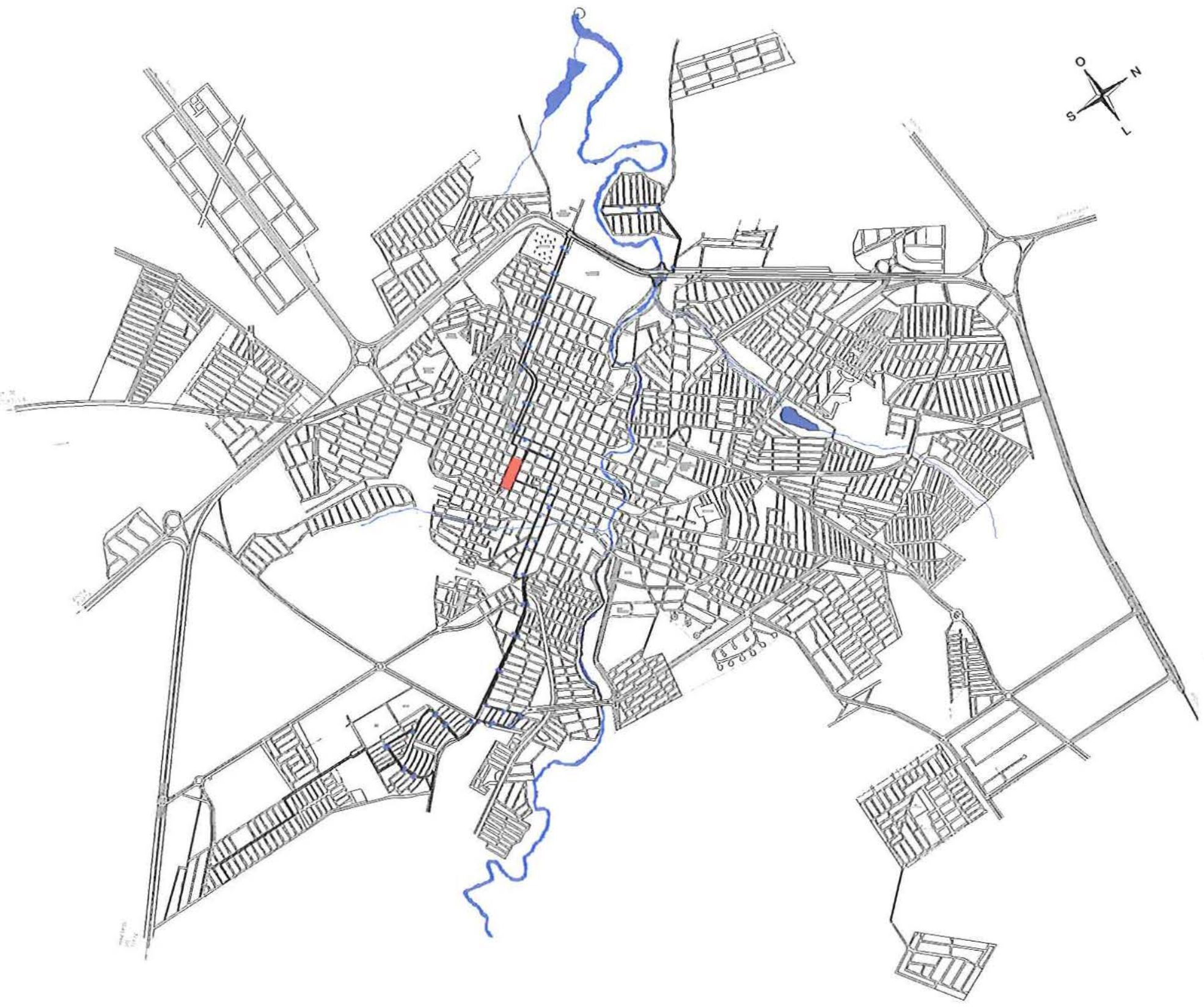


Linha 03 - Jd. Sempre Verde x Jd. Olimpia

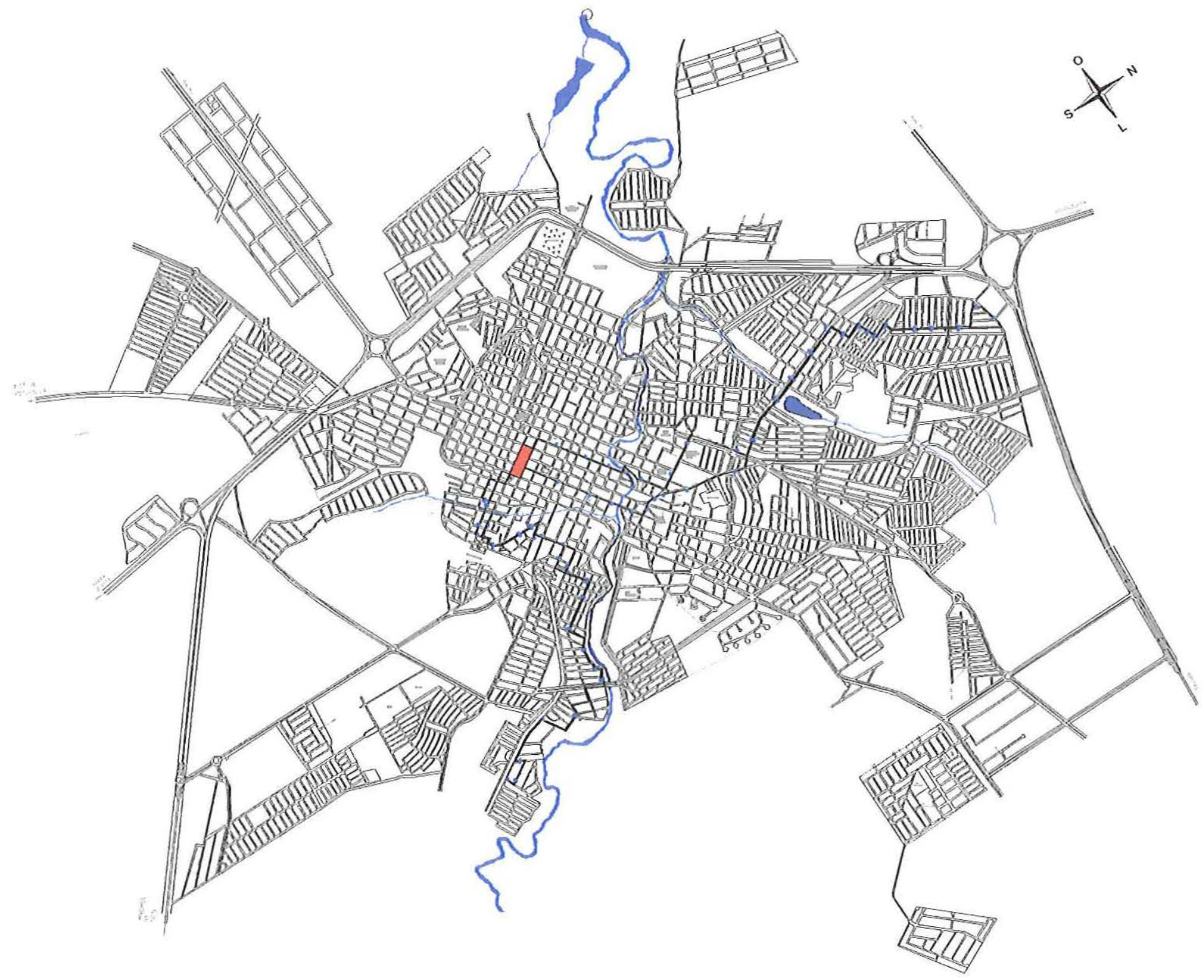


Linha 05 - Cemitério x Jd. Pedro Ometto

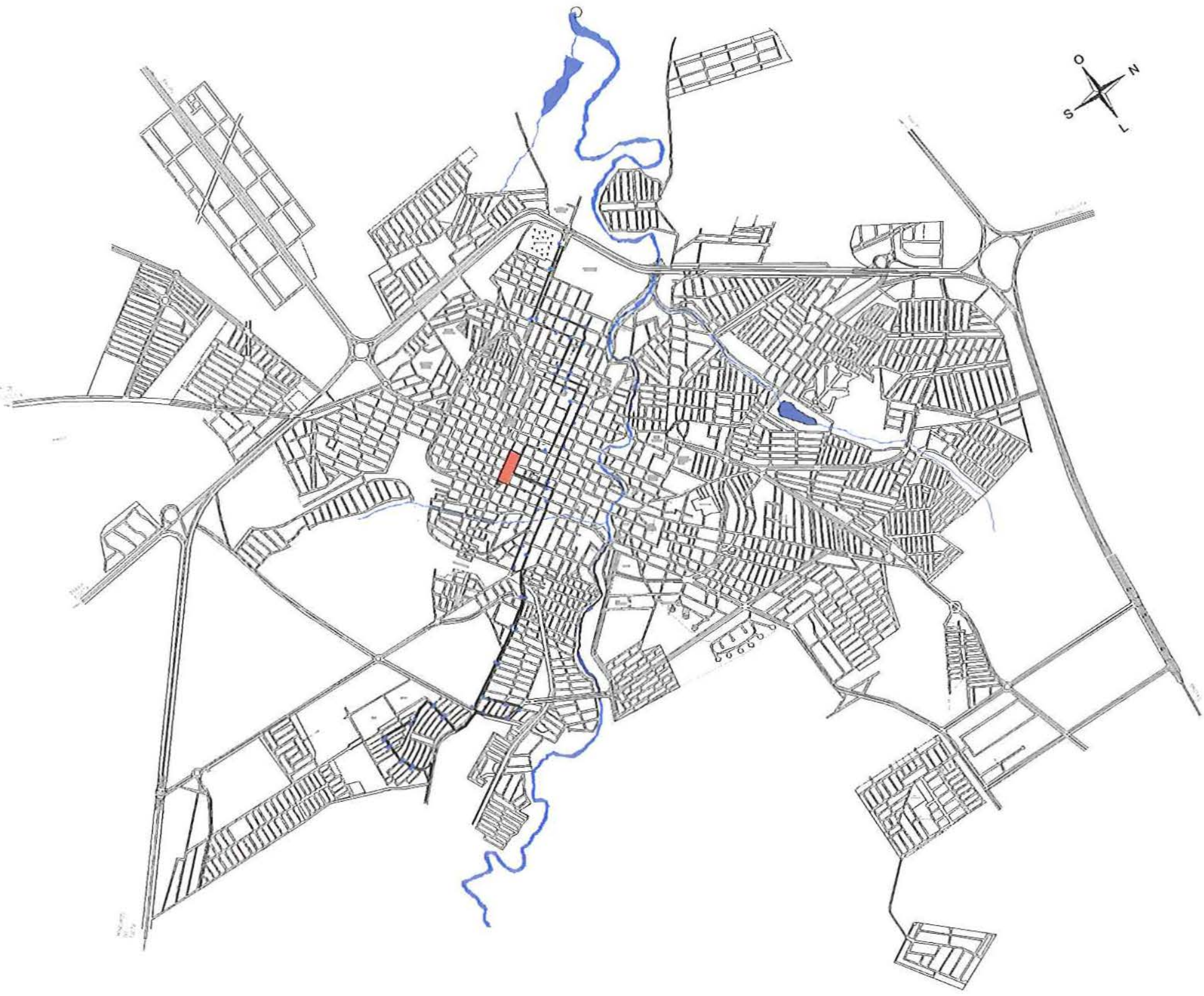


Linha 07 - Cemitério x Jd. Jorge Atalla

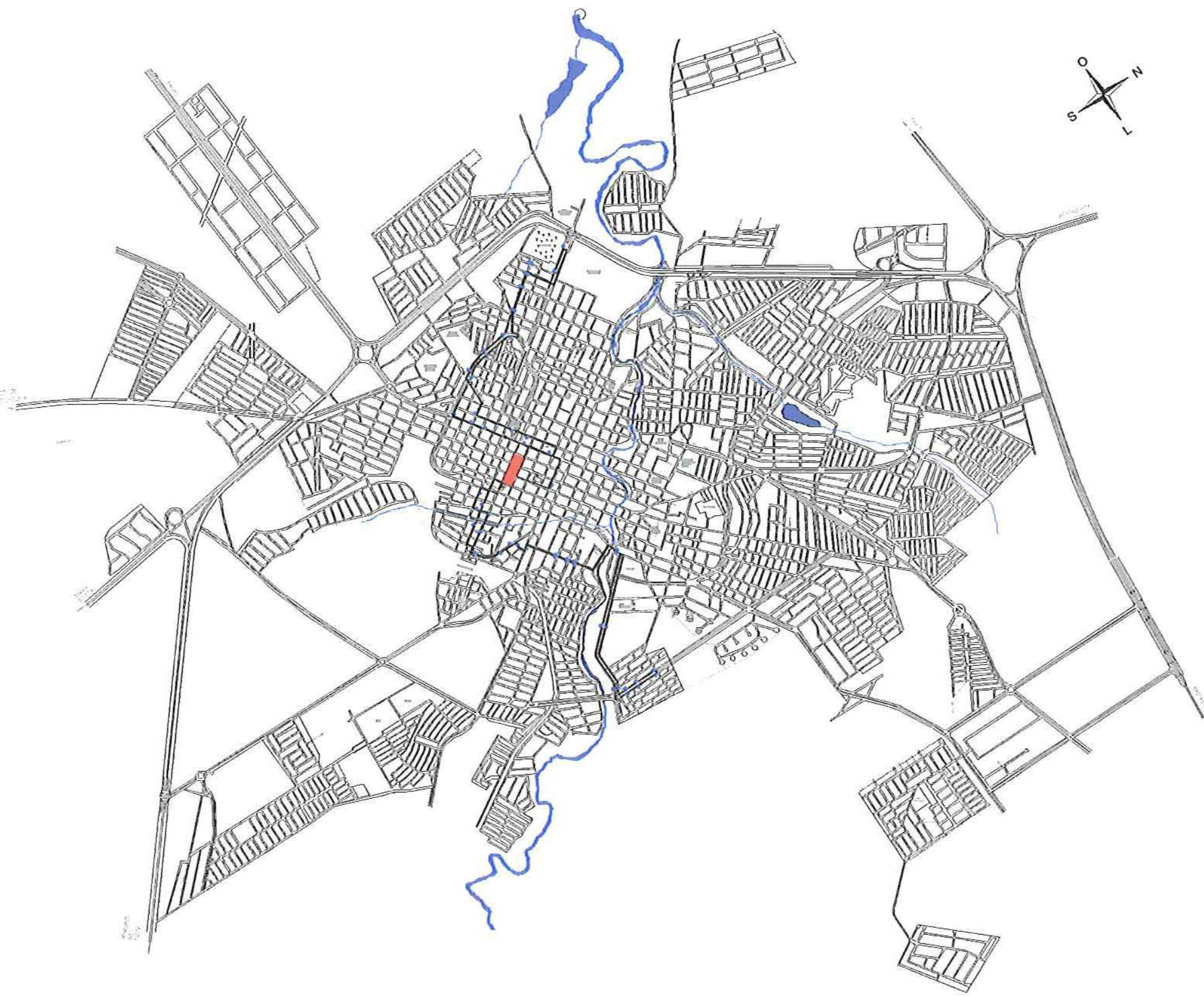


Linha 11 - Cemitério x Jd. Novo Horizonte

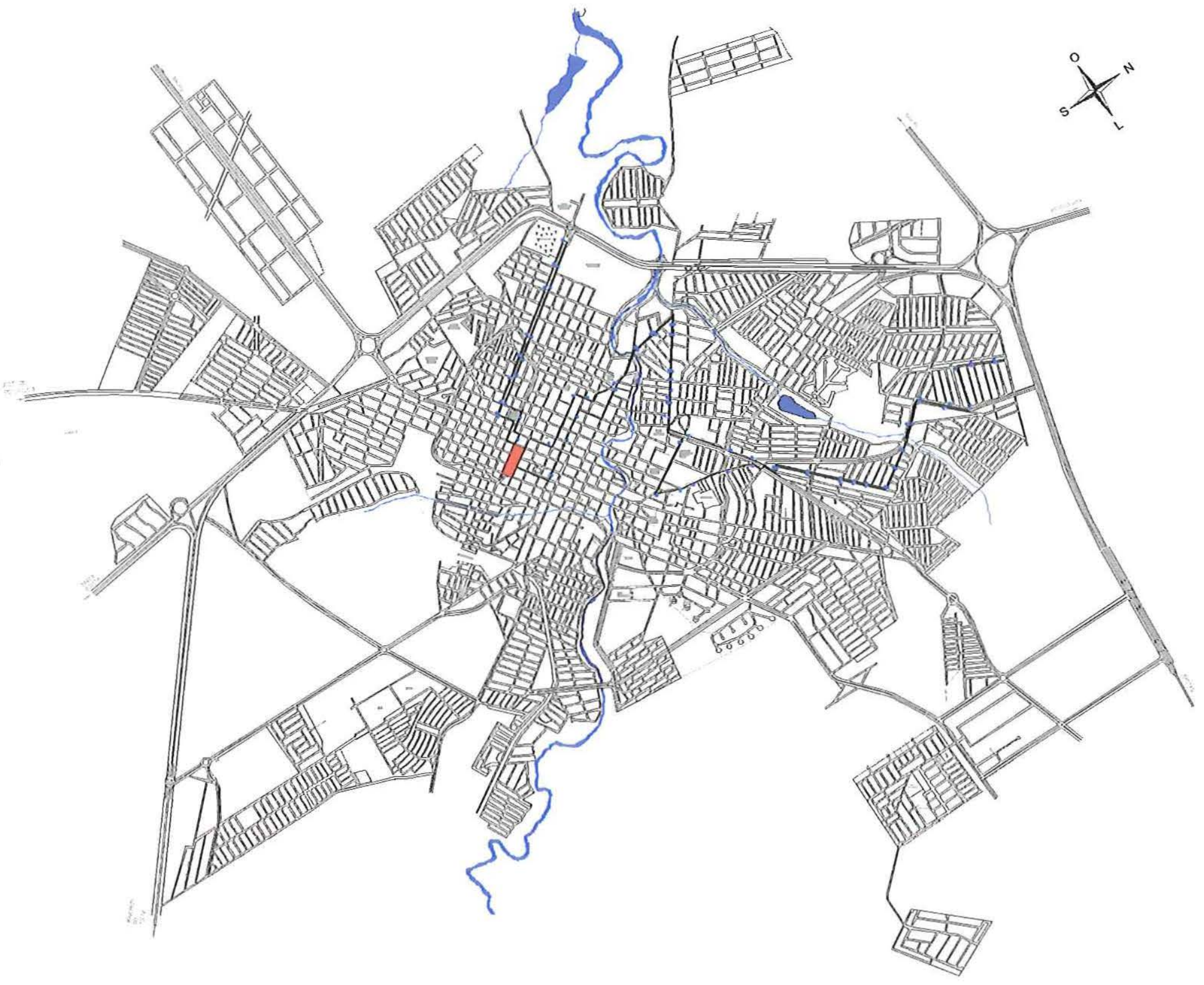


Linha 13 - Vila Maria x Jd. Sempre Verde

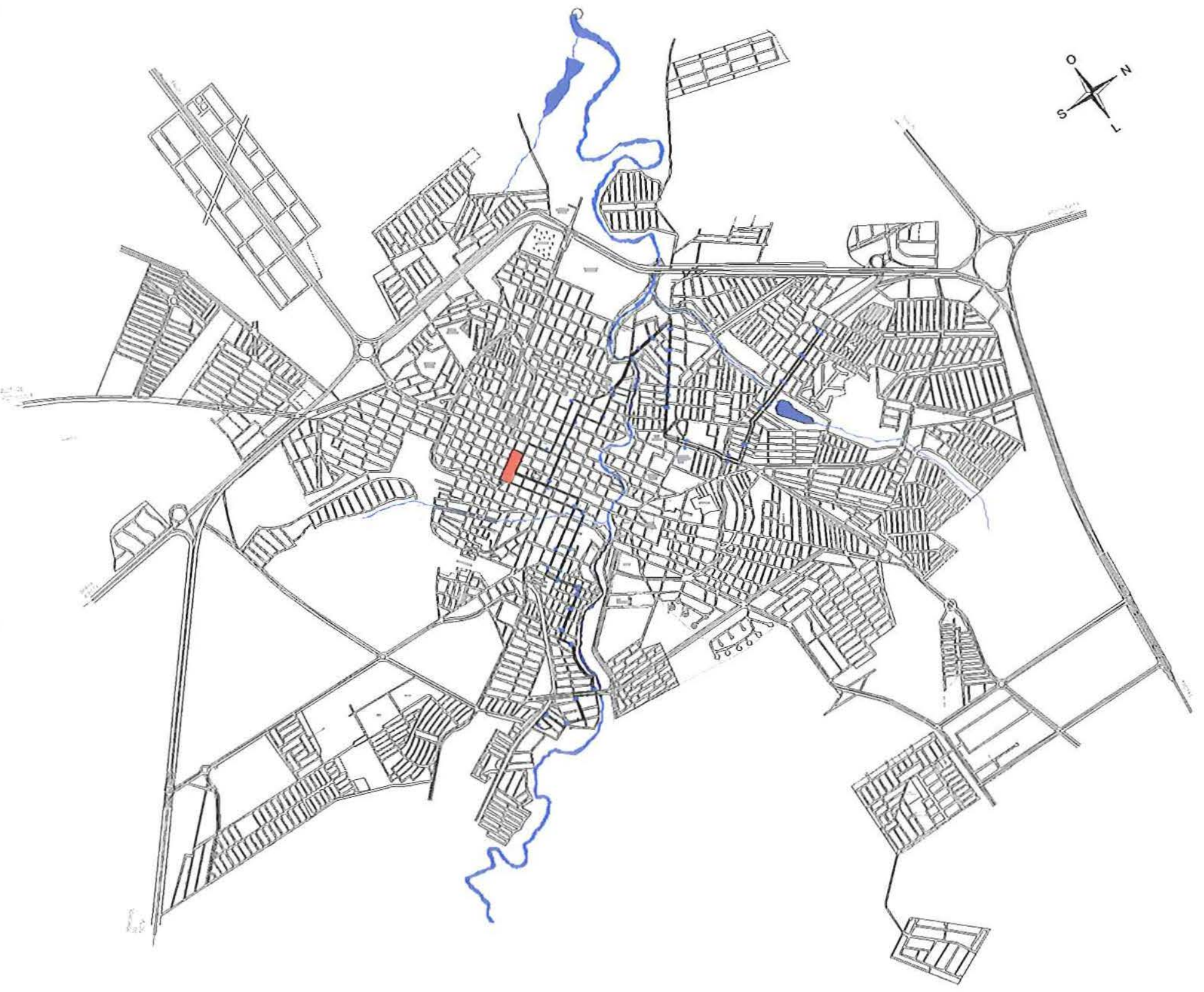


Linha 15 - Jd. Carolina x Cemitério

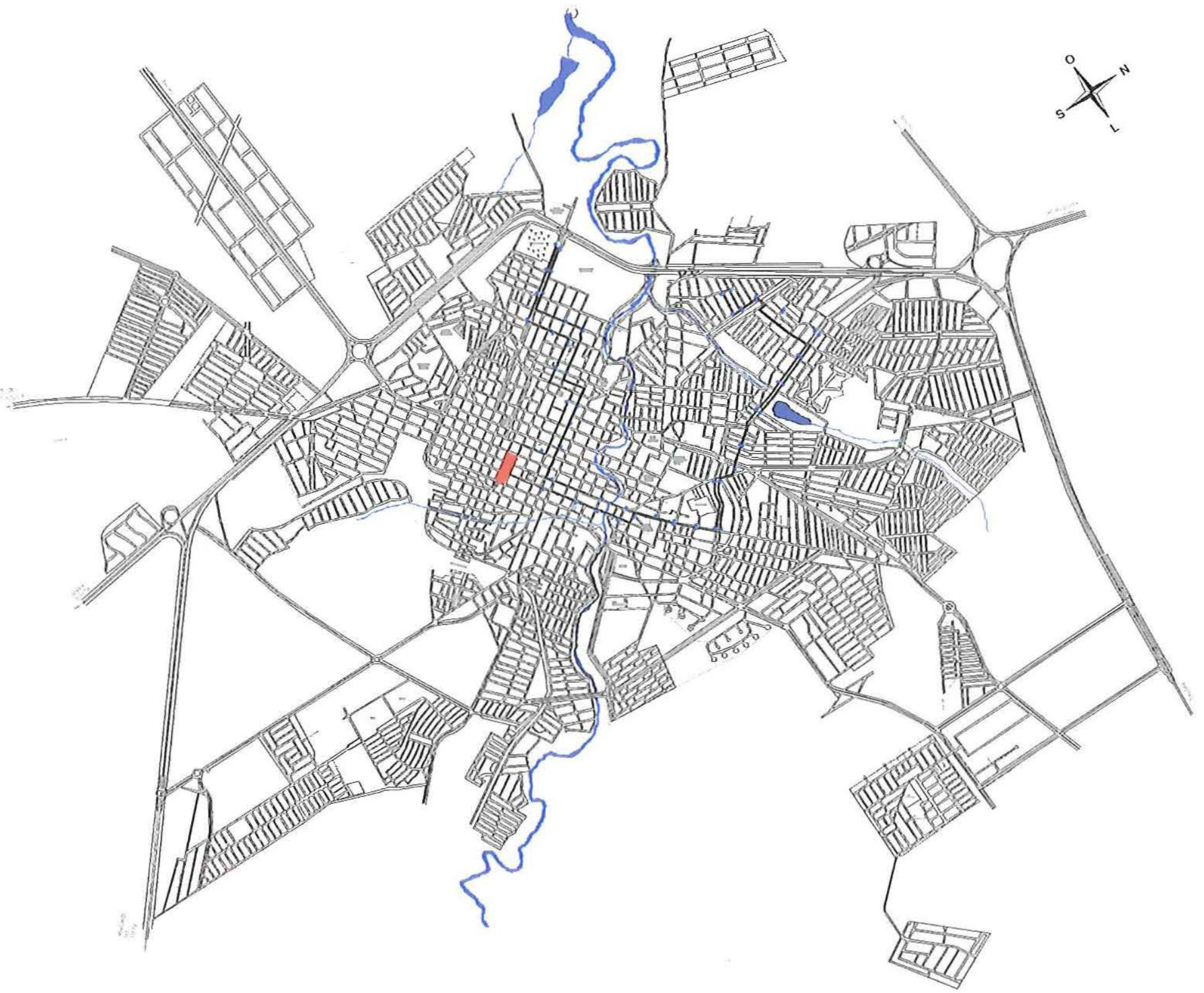

- Terminal Rodoviário 
Linha 17 - Jd. Pedro Ometto x Jd. São José

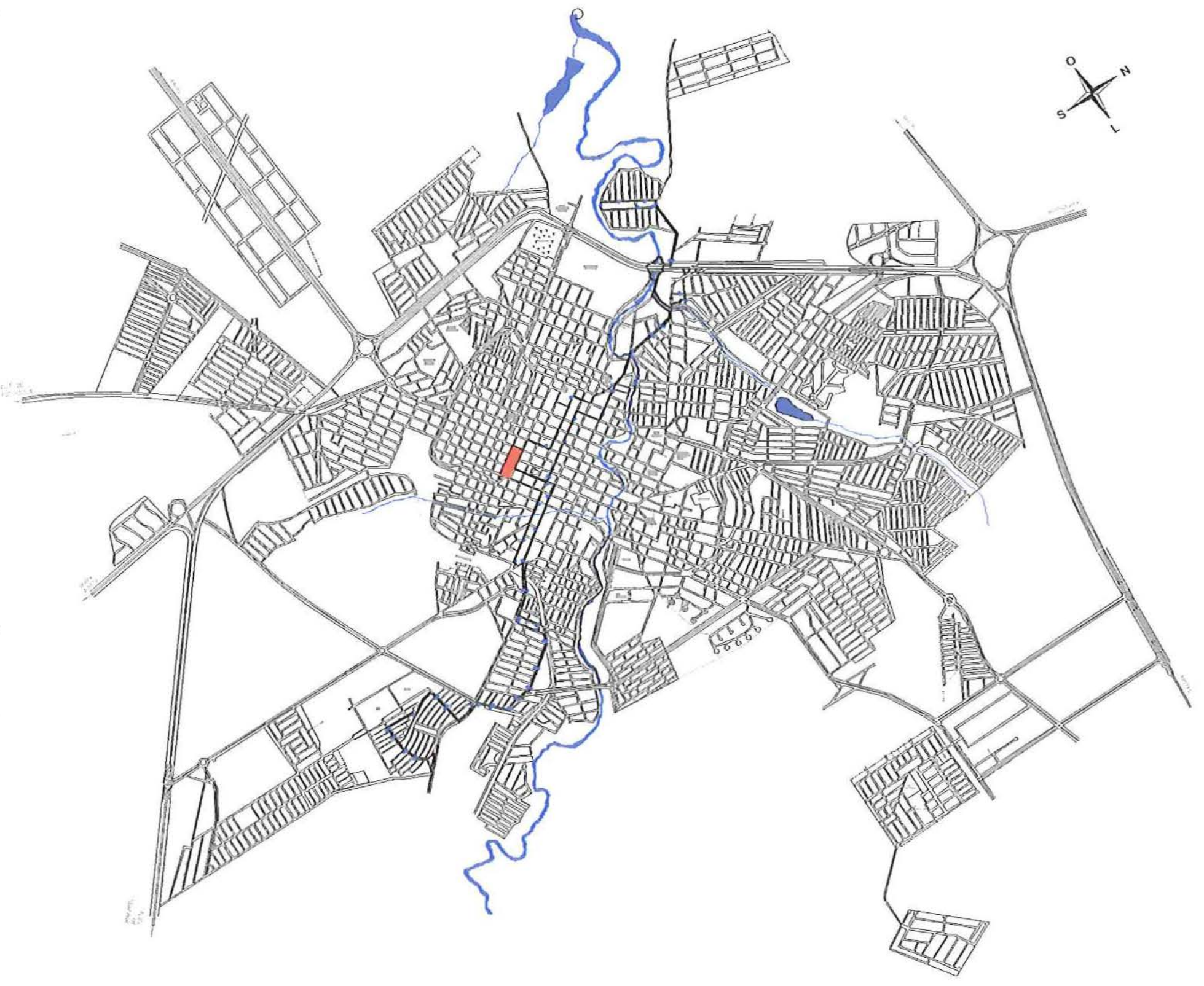


Linha 19 - Cemitério x Jd. América

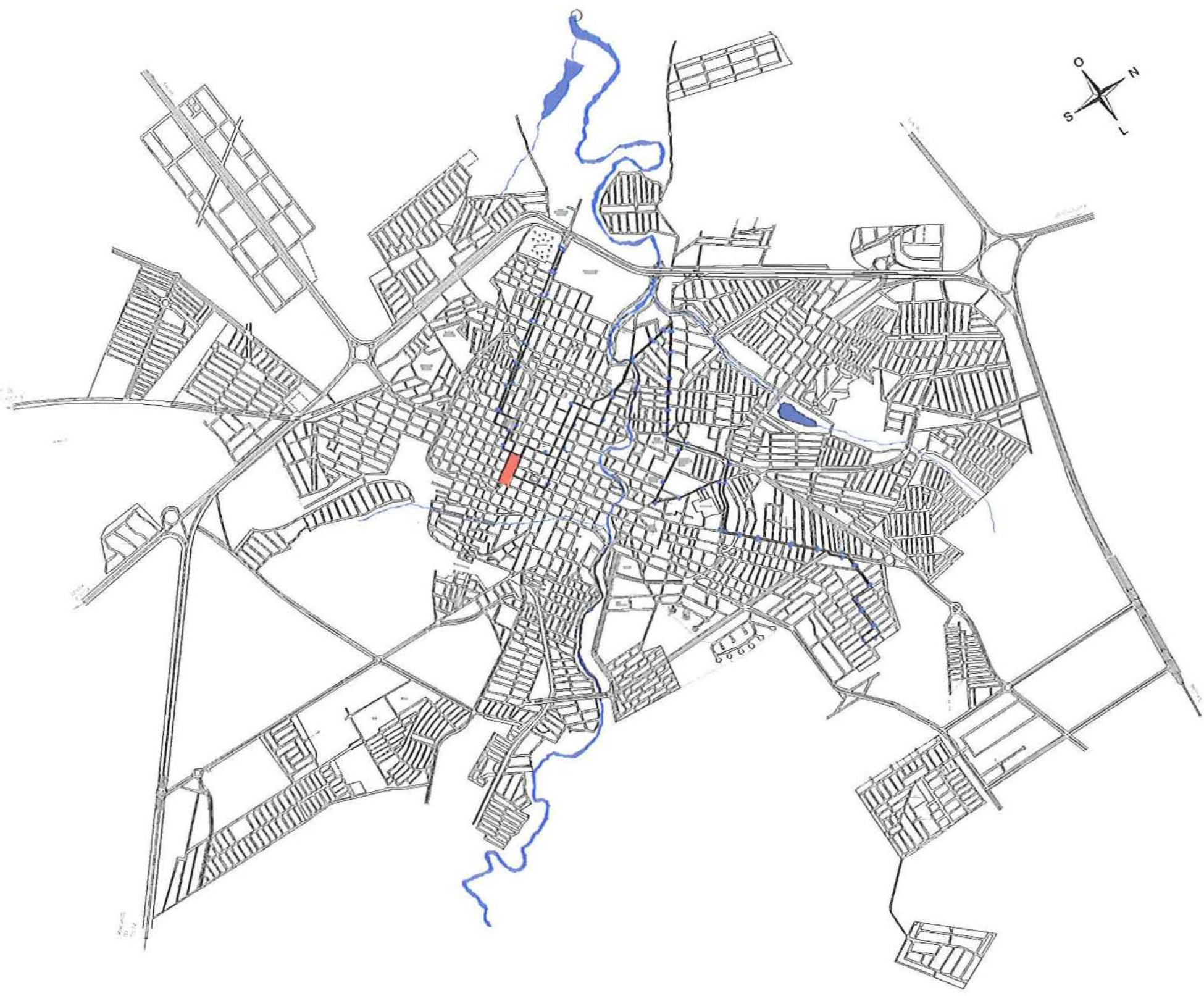


Linha 21 -Cemitério x Jd. Ferreira Dias

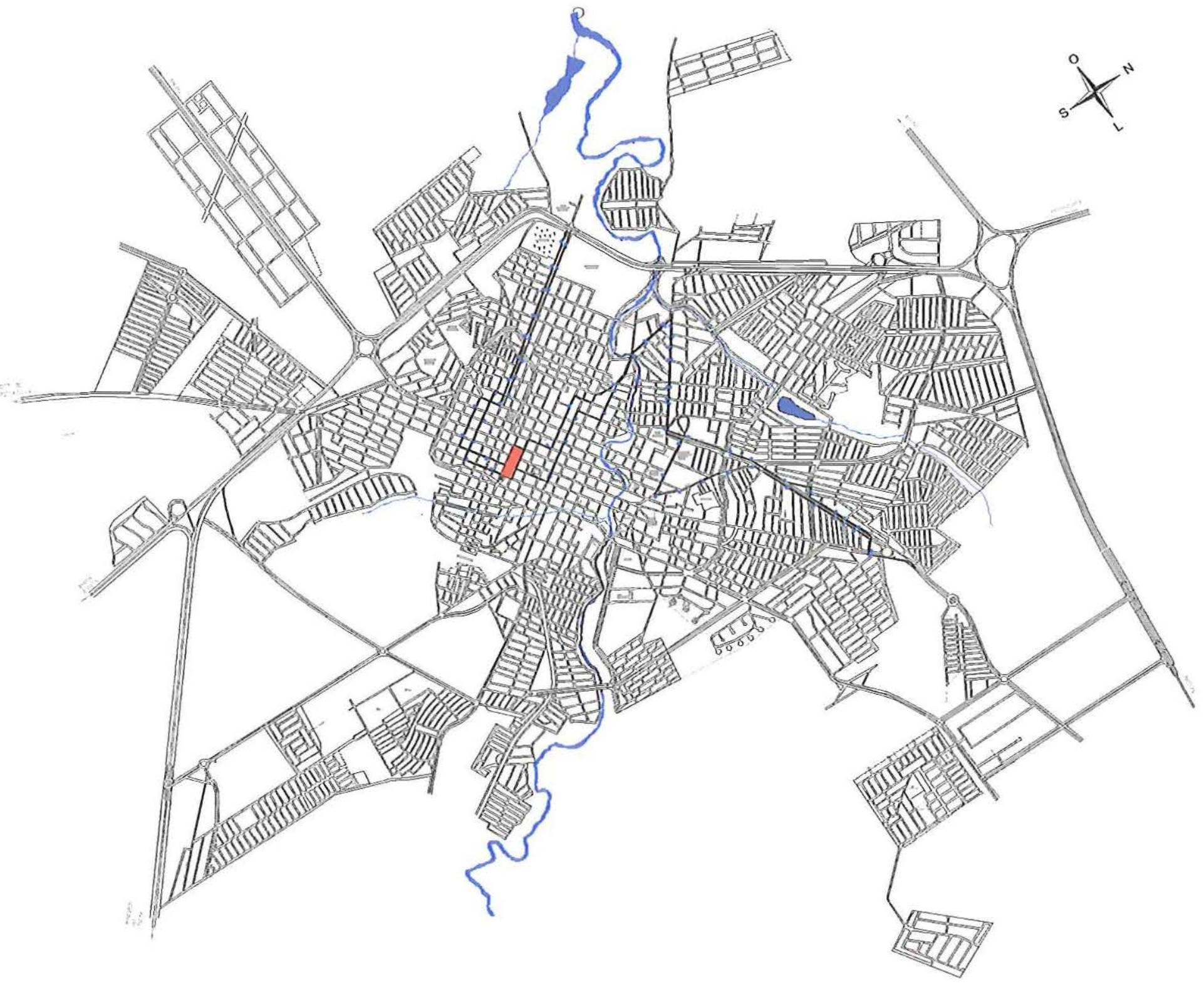

- Terminal Rodoviário 


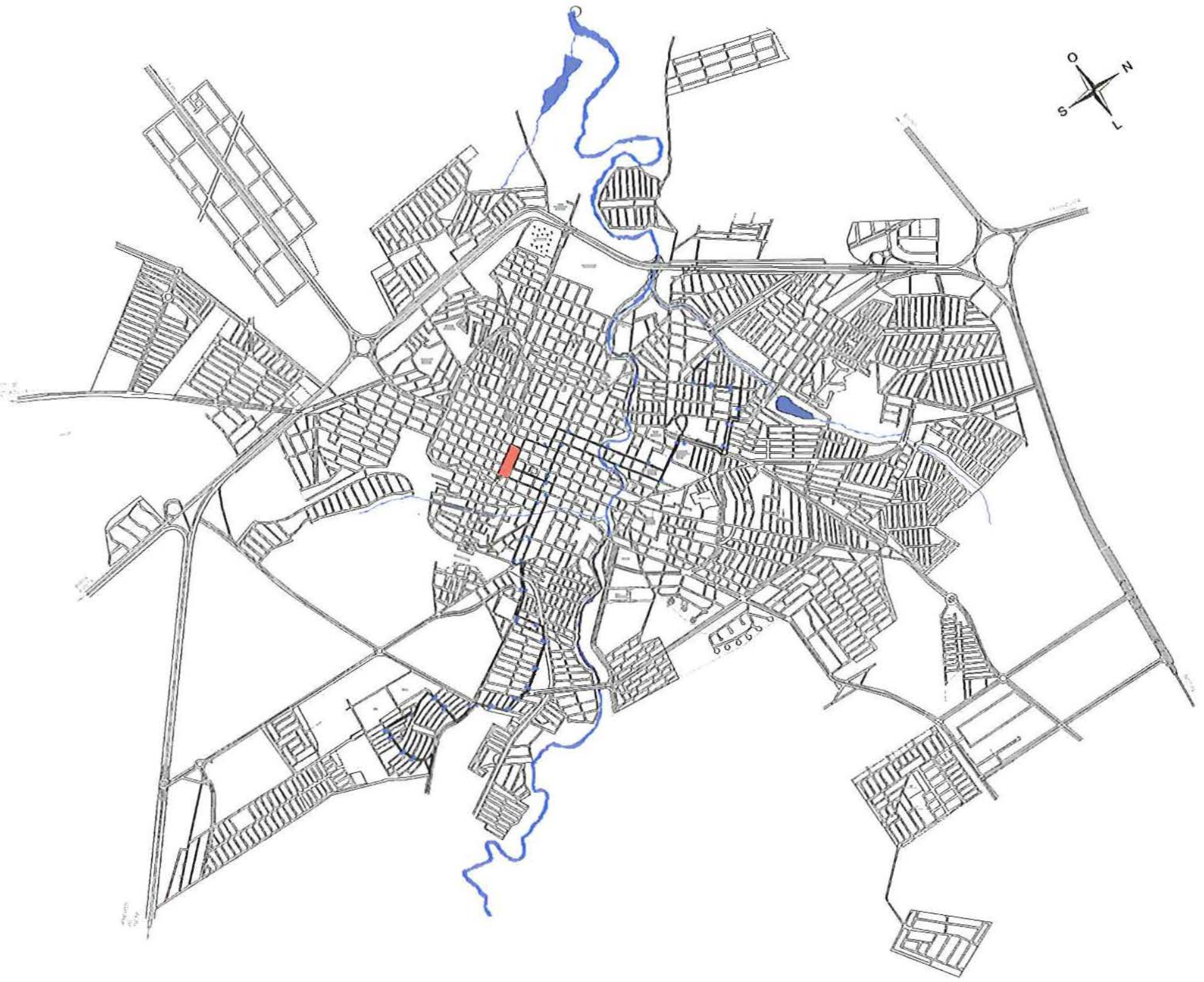

- Terminal Rodoviário 
Linha 25 - Jd. Odete x Jd. Ferreira Dias

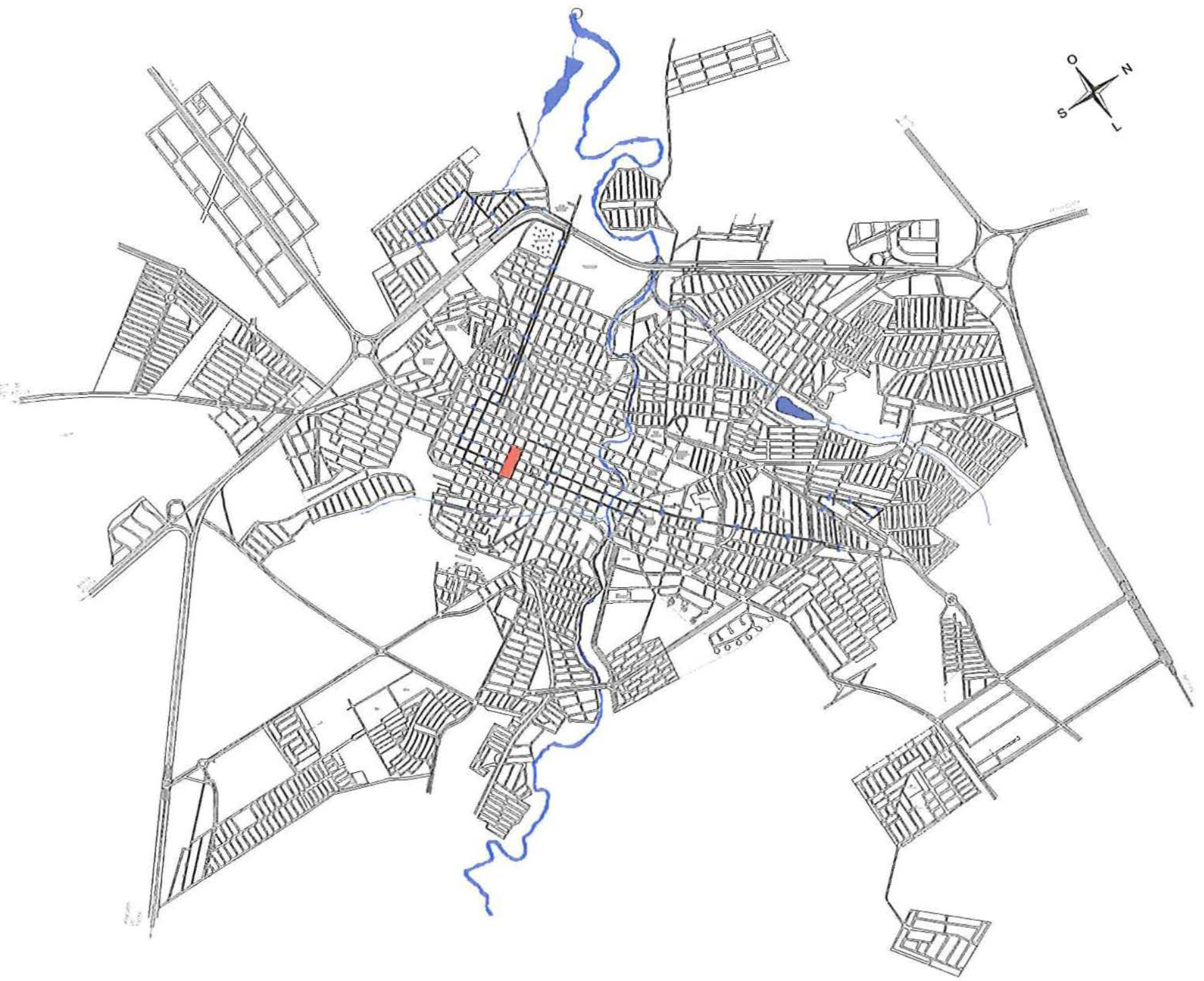

- Terminal Rodoviário 
Linha 27 Jd. Olimpia x Jd. Nova Jahu

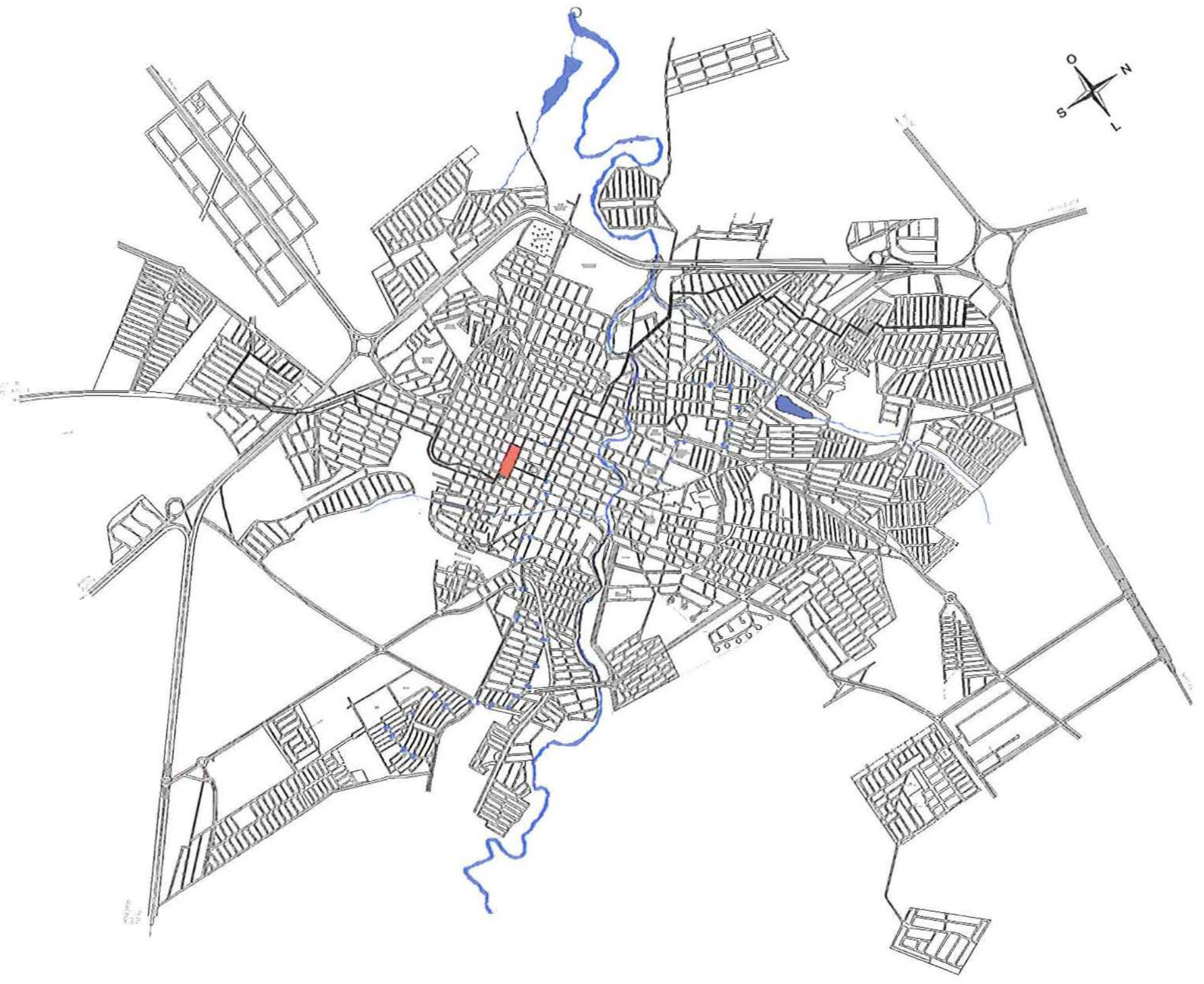

- Terminal Rodoviário 
Linha 29 - Jd. Nova Jahu x Jd. América

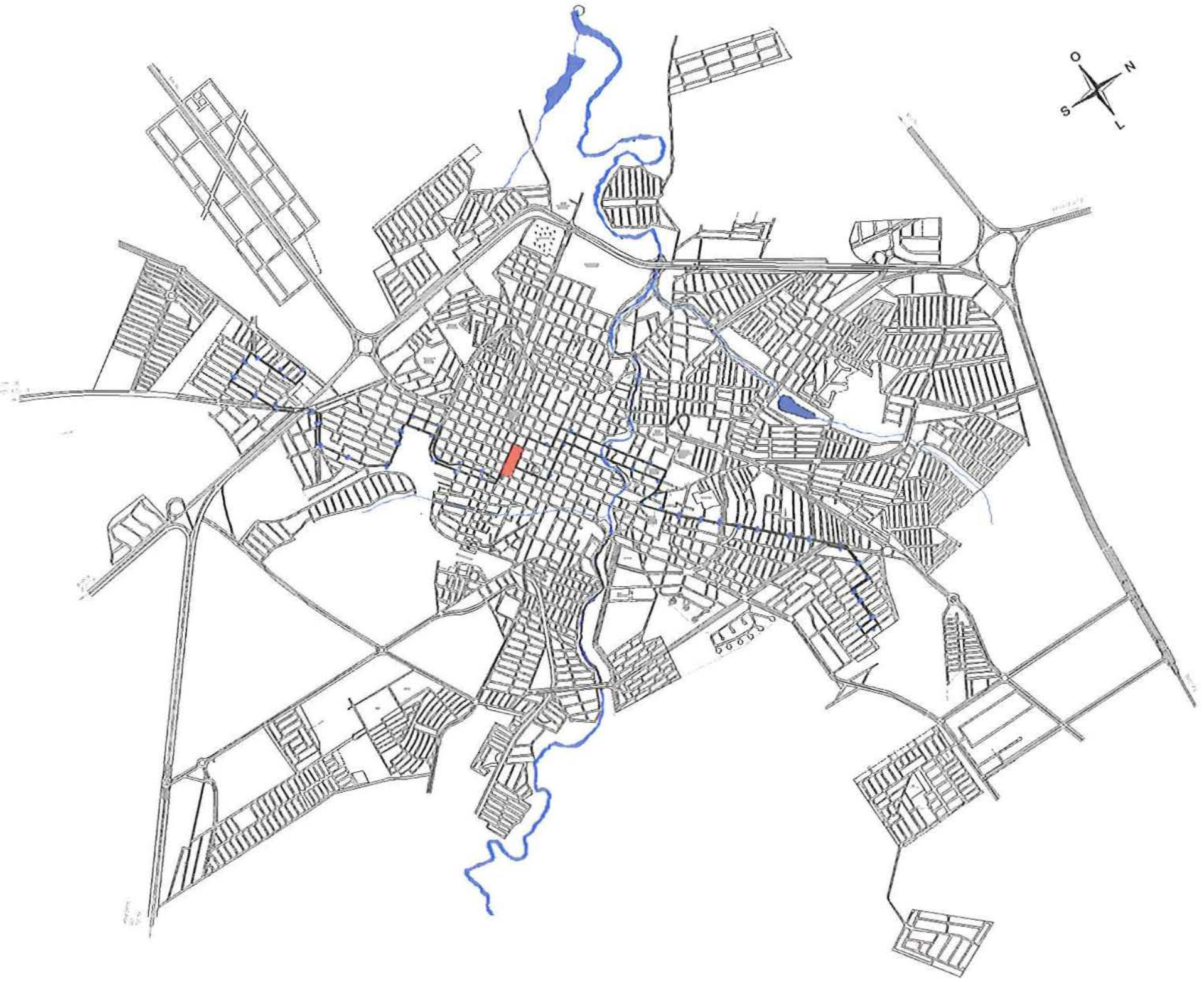


Linha 31 - Jd. St ${ }^{\mathrm{a}}$. Helena x Jd. Olimpia

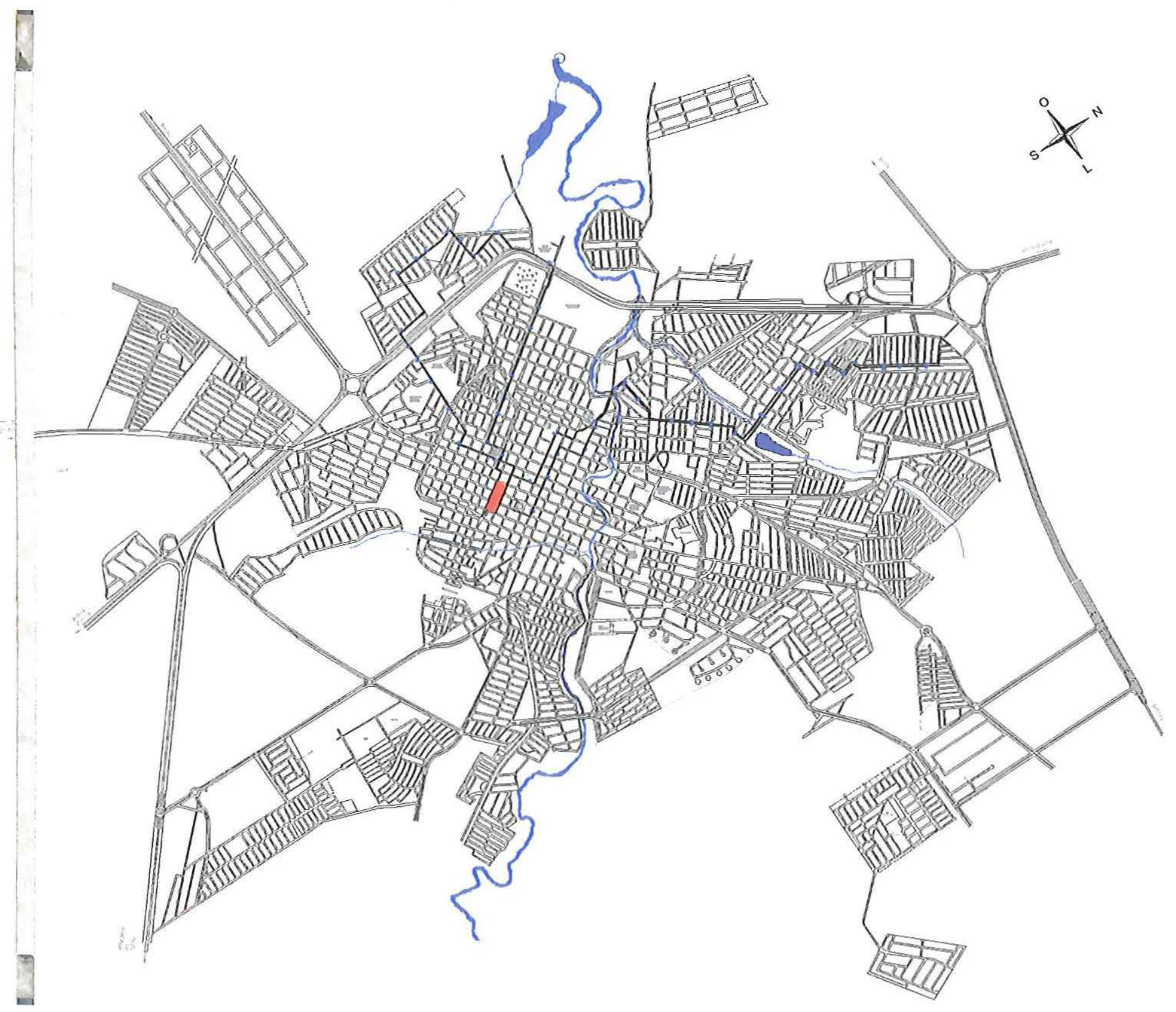

- Terminal Rodoviário 
Linha 39 - Jd. Vilagio di Roma x Jd. Maria Luiza IV

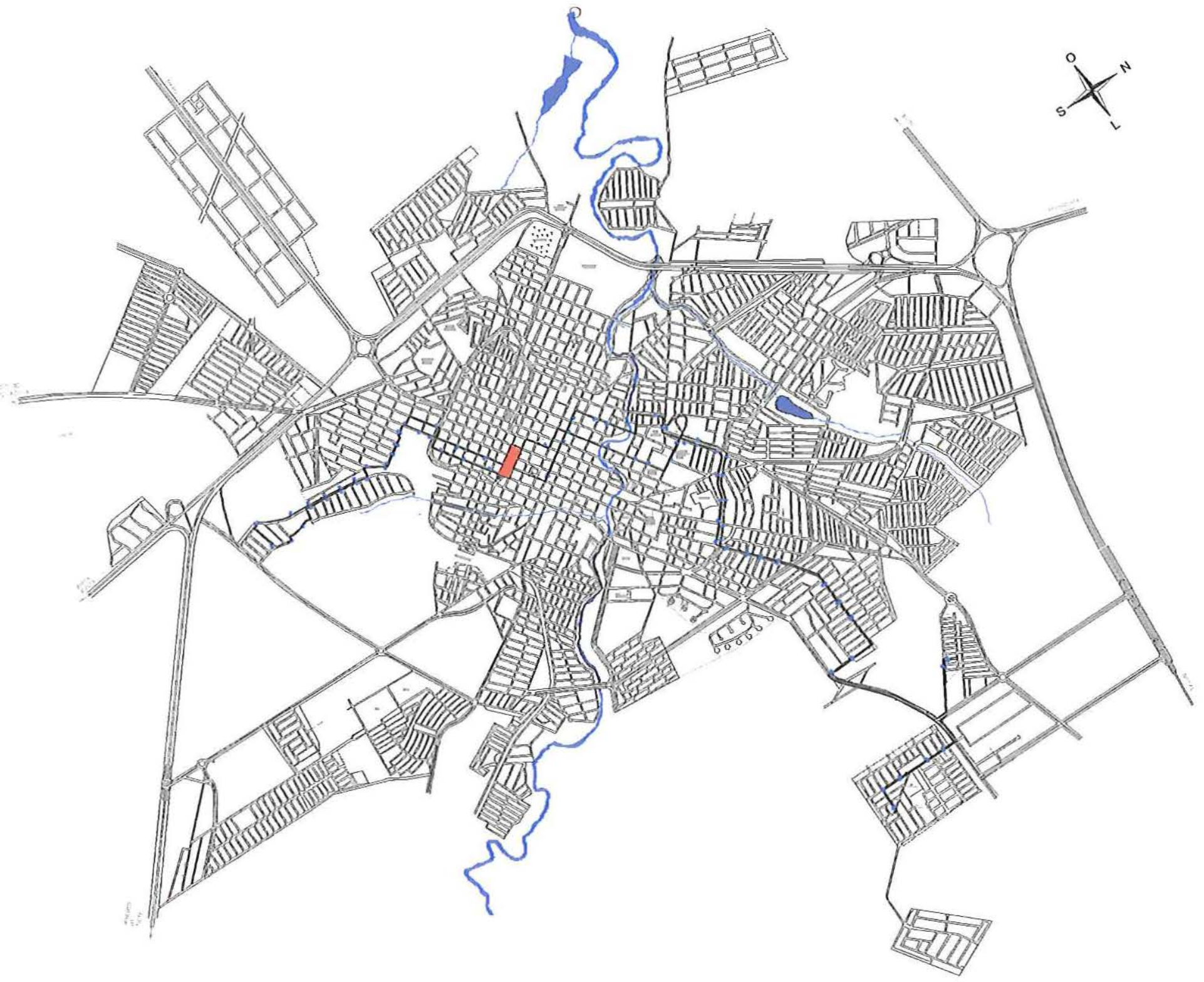

- Terminal Rodoviário 
Linha 51 - Jd. Maria Luiza IV x Jd. Novo Horizonte

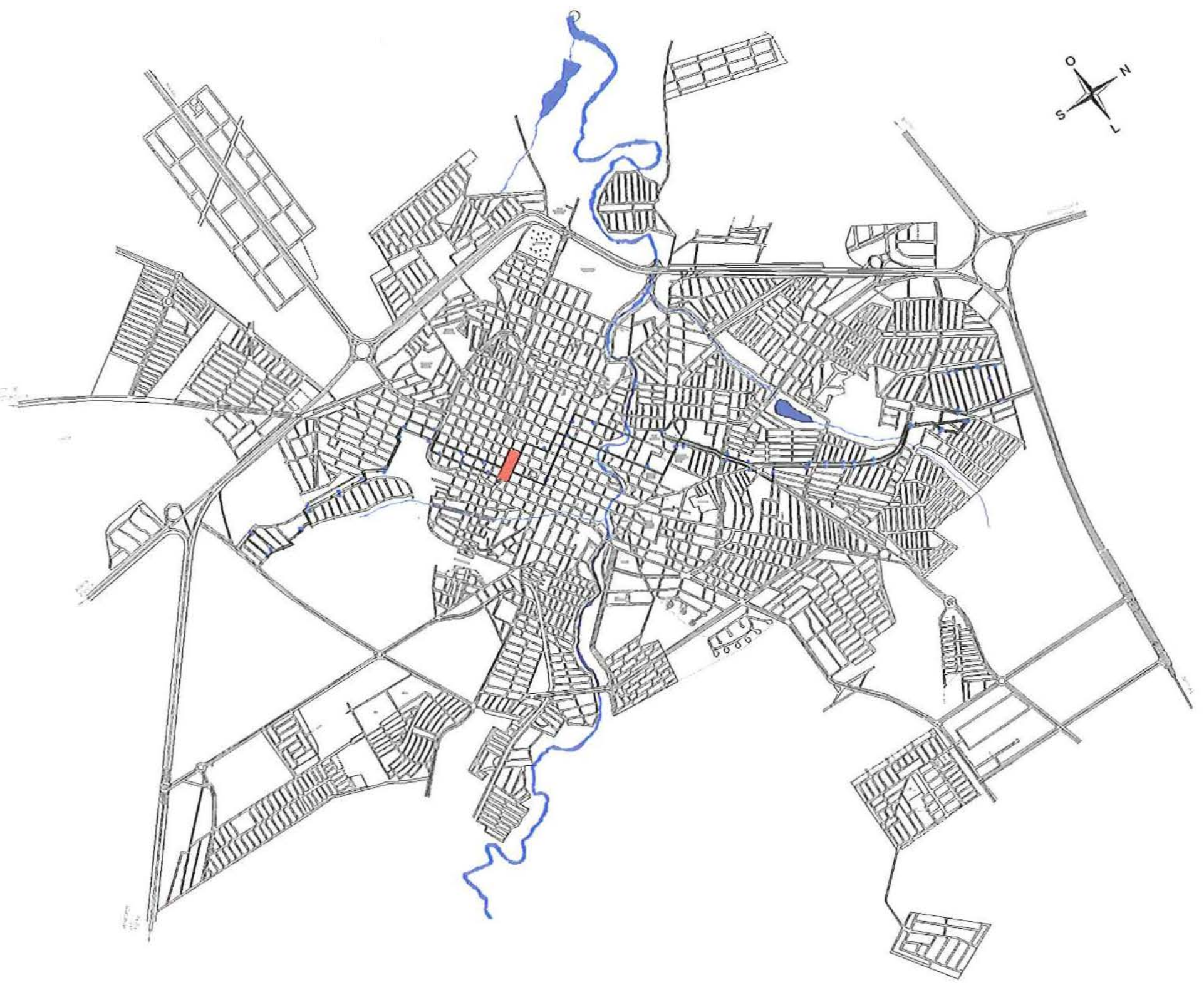

- Terminal Rodoviário 
Linha 53 - Jd. Orlando Ometto x $\mathrm{St}^{\mathrm{a}}$. Casa

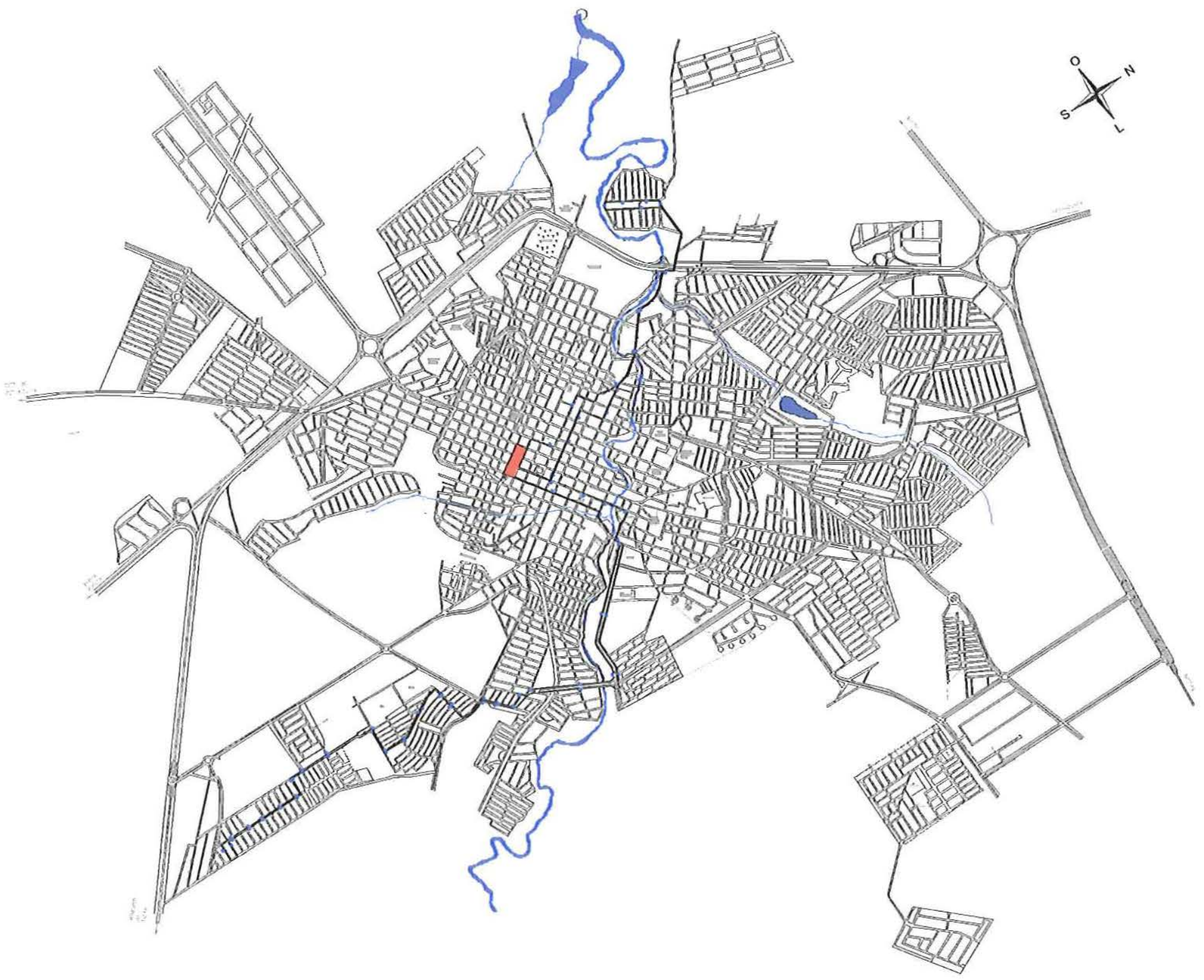


Linha 55 - Jd. Padre ${ }^{\text {a }}$ Sani x Jd. São José

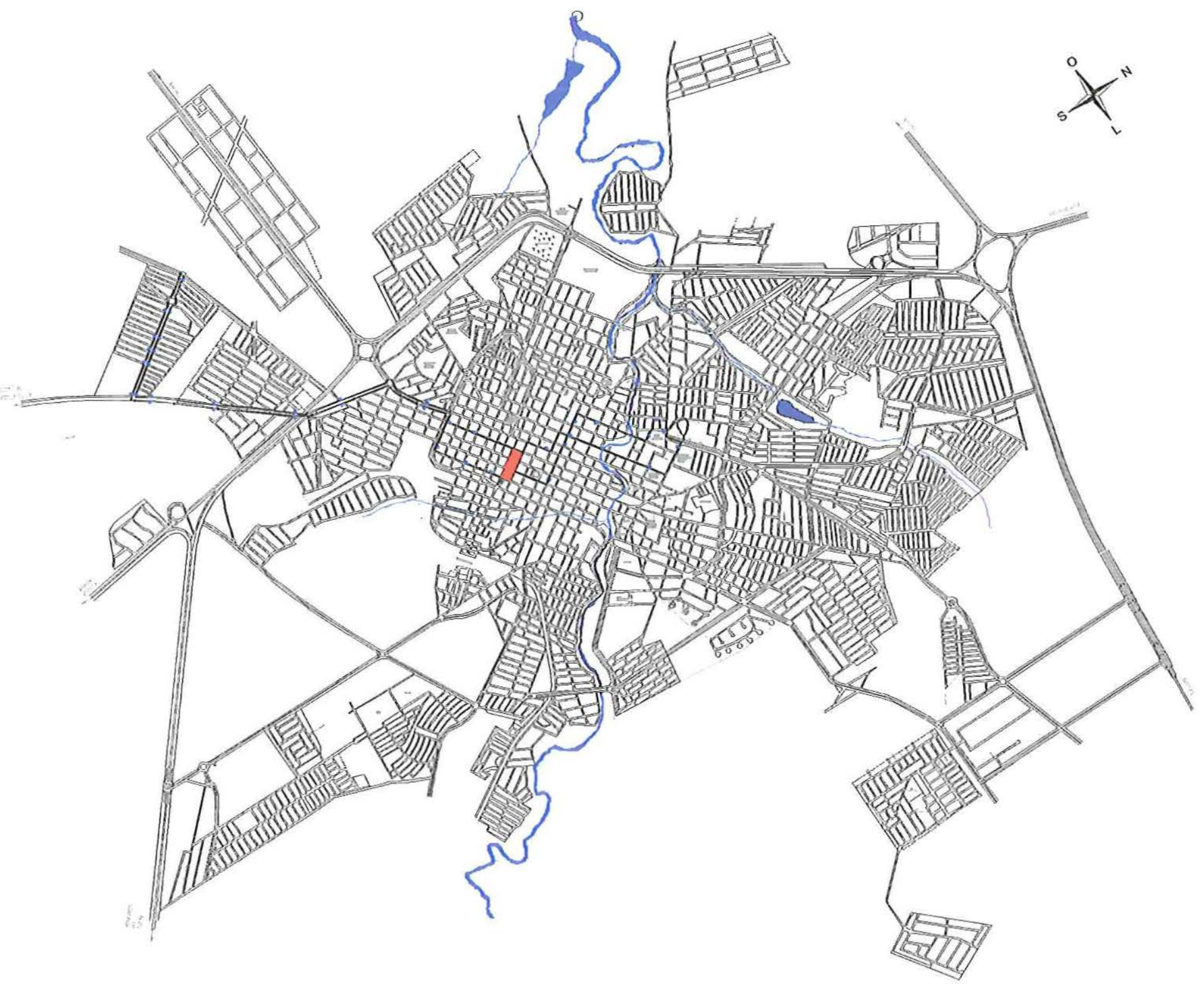

- Terminal Rodoviário 
Linha 57 - Jd. Maria Luiza x Jd. Vilagio di Roma

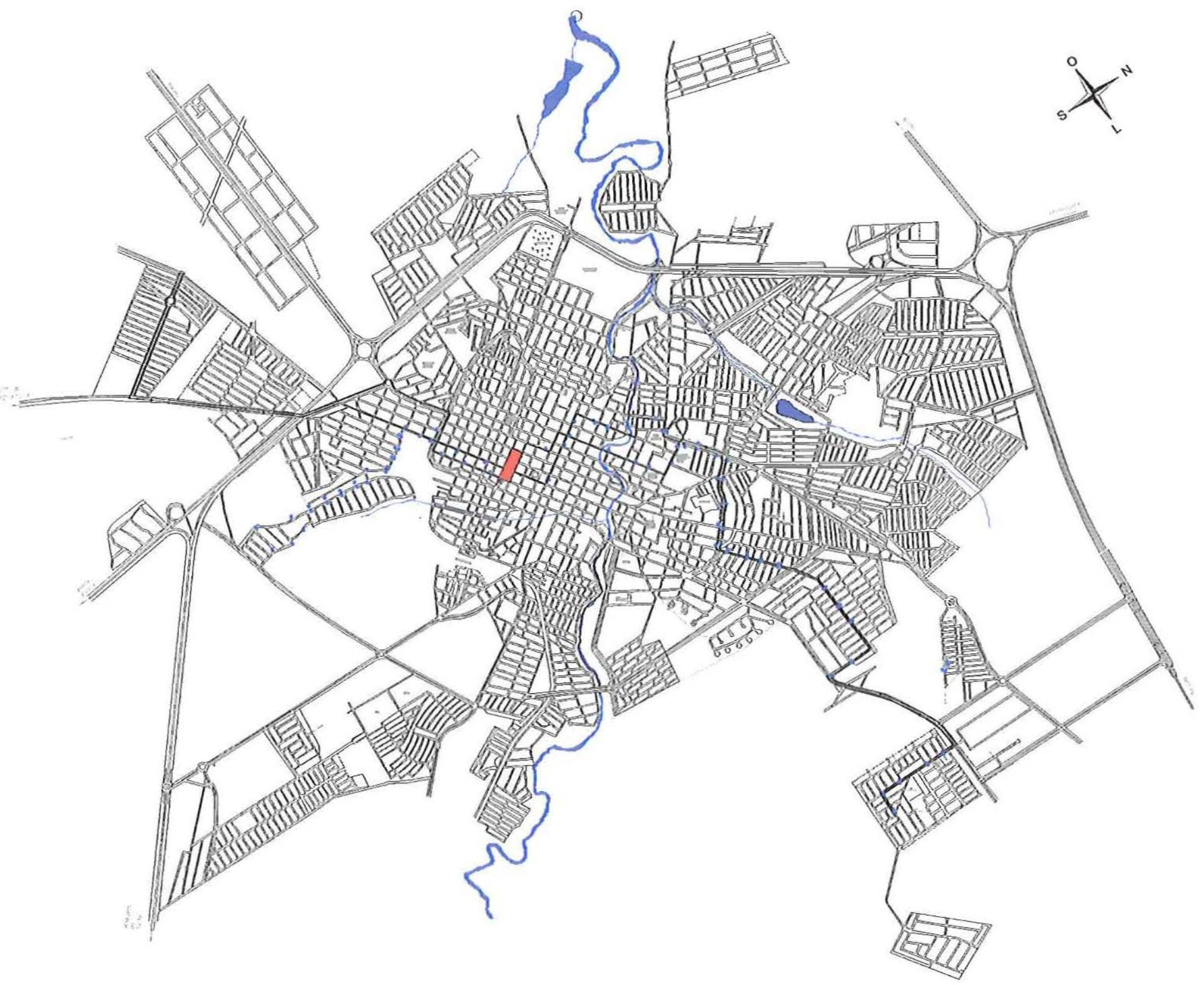

- Terminal Rodoviário 


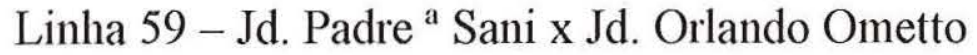

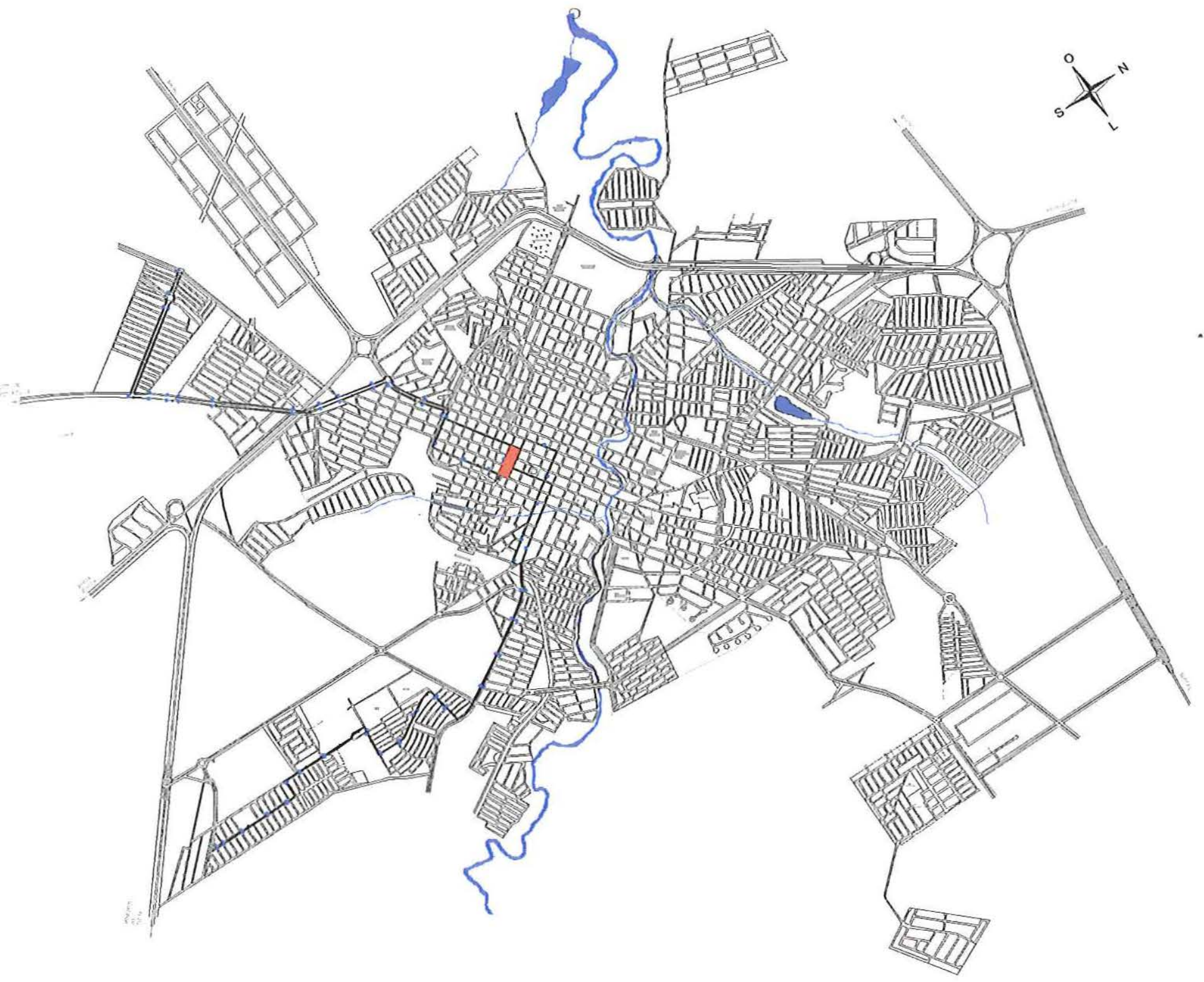

- Terminal Rodoviário 
Linha 61 - Jd. Parati $x \mathrm{St}^{\mathrm{a}}$. Casa

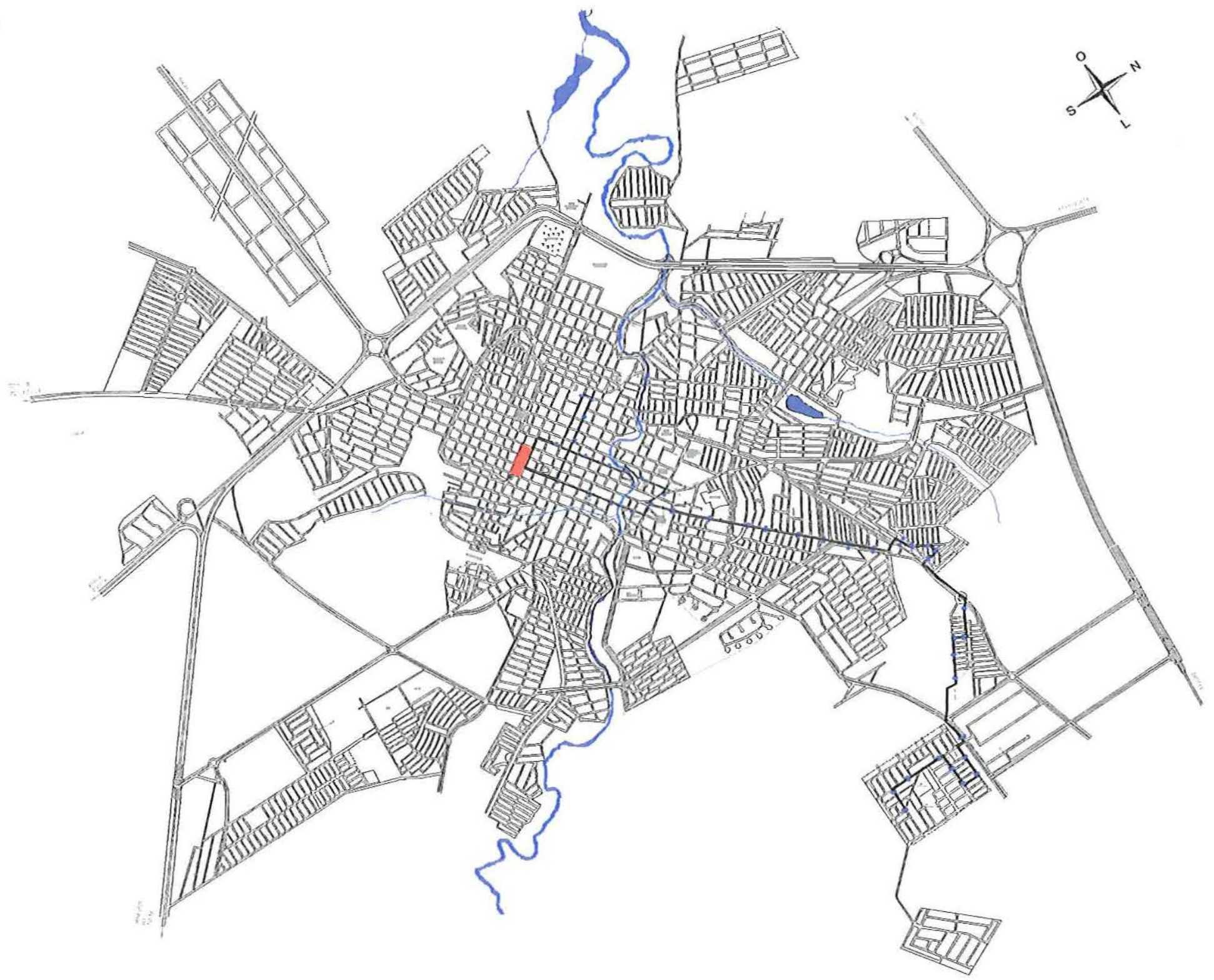

- Terminal Rodoviário 
Linha 63 - Jd. João Balan x Jd. Sanzovo

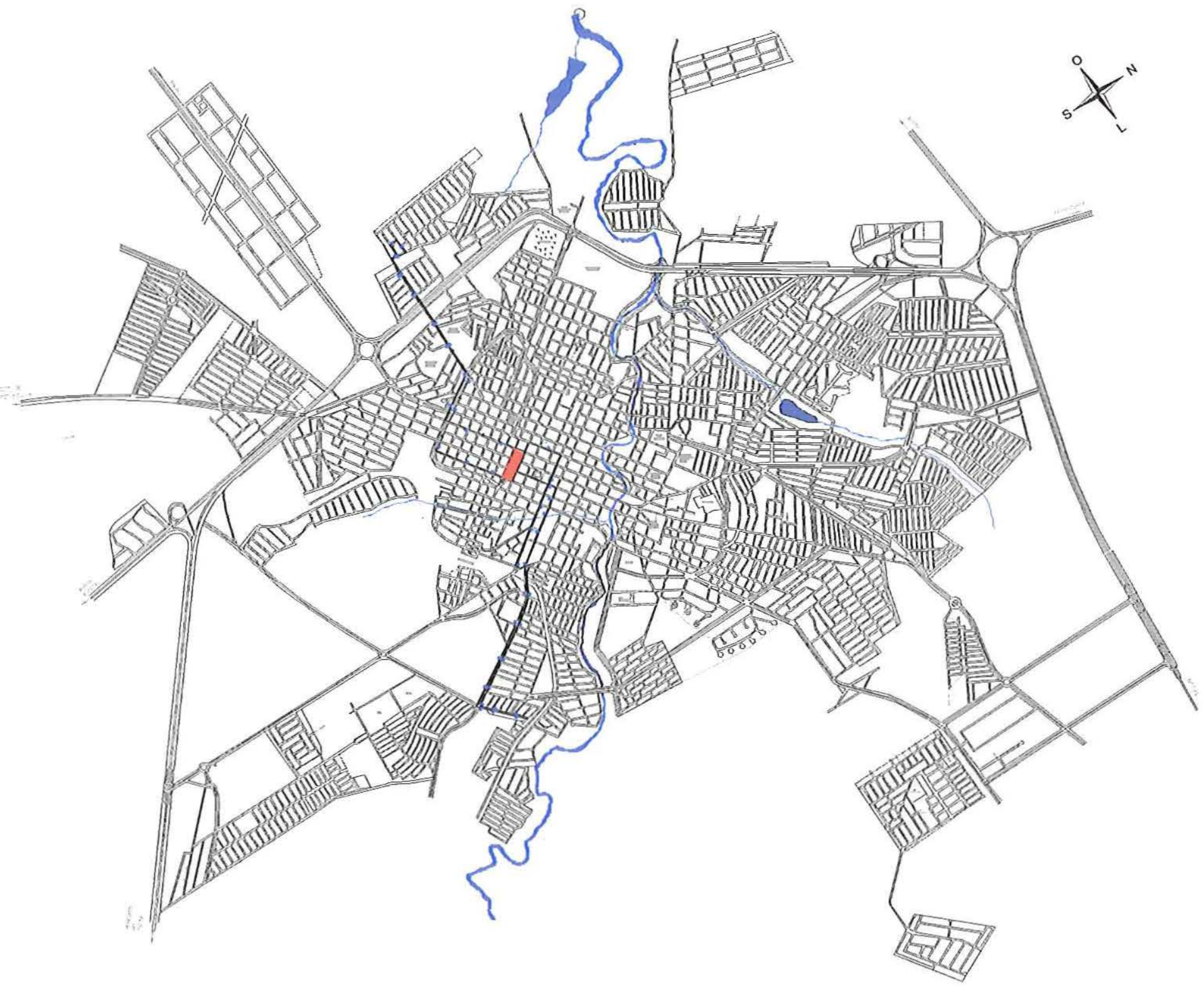


Rede Viária

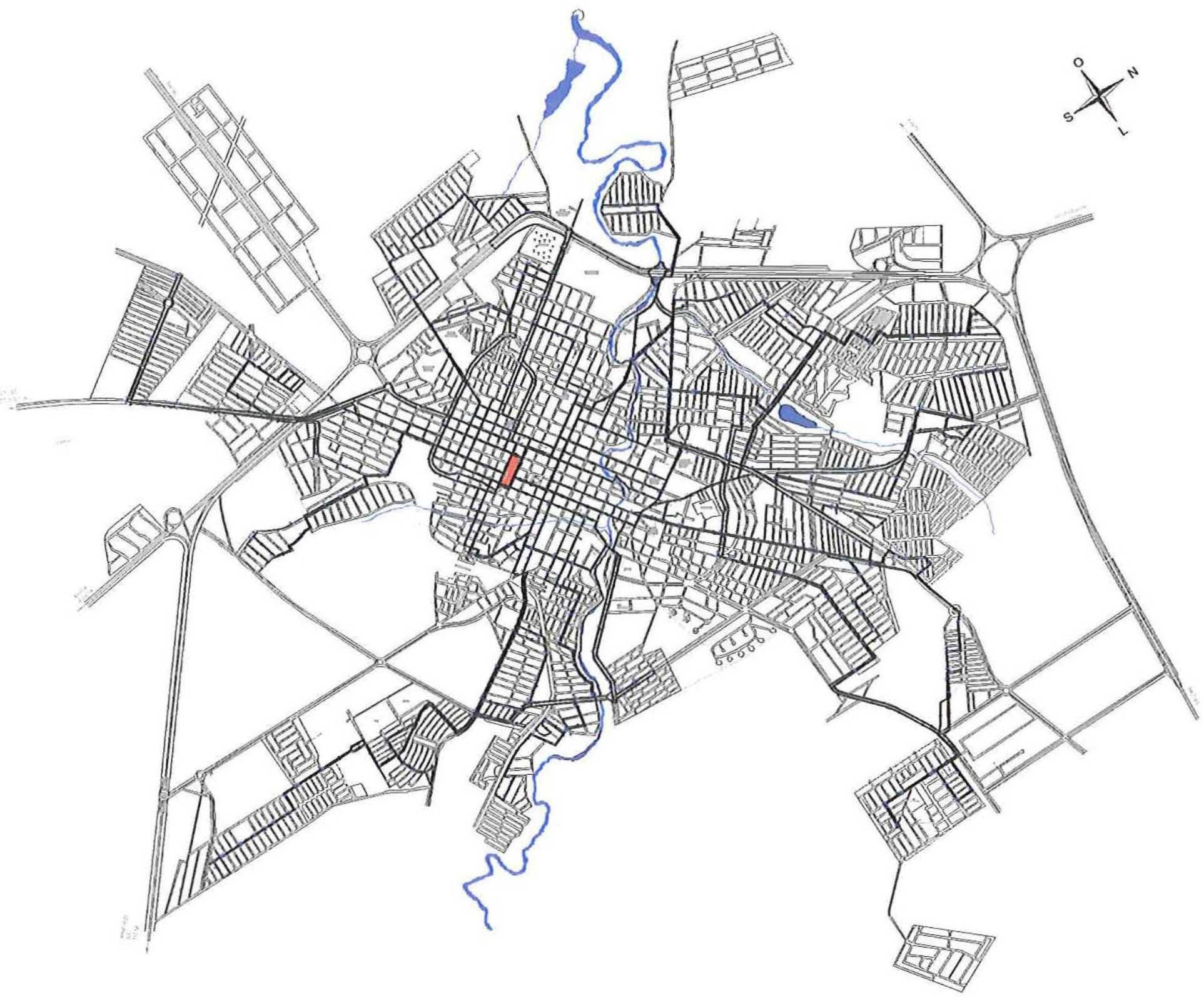

- Terminal Rodoviário 


\section{Anexo-2,3,4,5,6,7 e 8}

Resultado das pesquisas de opinião com-

a- Usuários

b- Comunidade

c- Governo 
Intervalo entre a passagem dos ônibus - opinião dos usuários

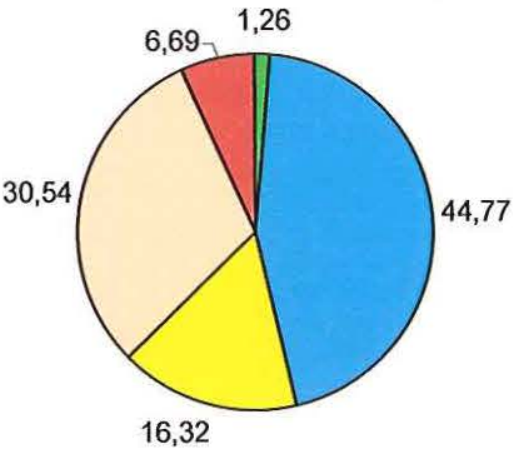

16,32

Figura 1 - Intervalo entre a passagem de dois ônibus

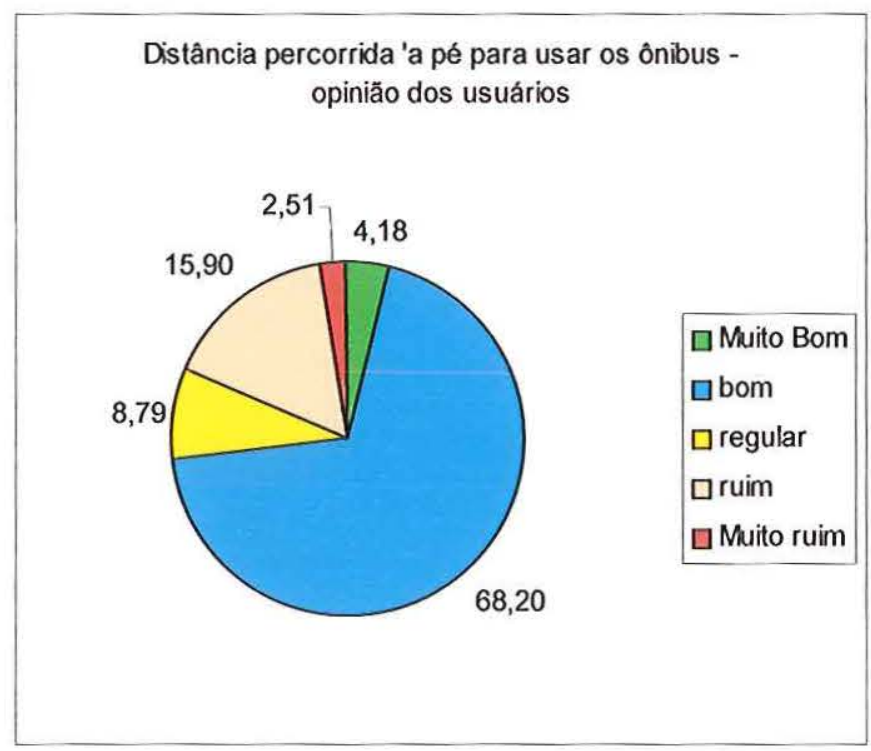

Figura 2 - Distância percorrida 'a pé para usar os ônibus 


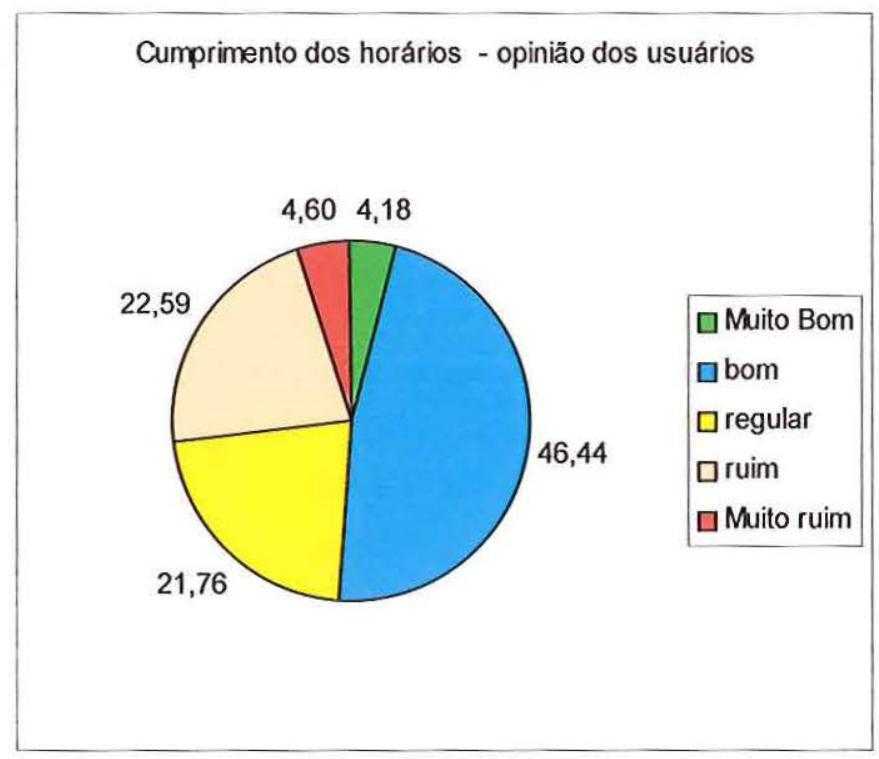

Figura 3 - Cumprimento dos horários 0

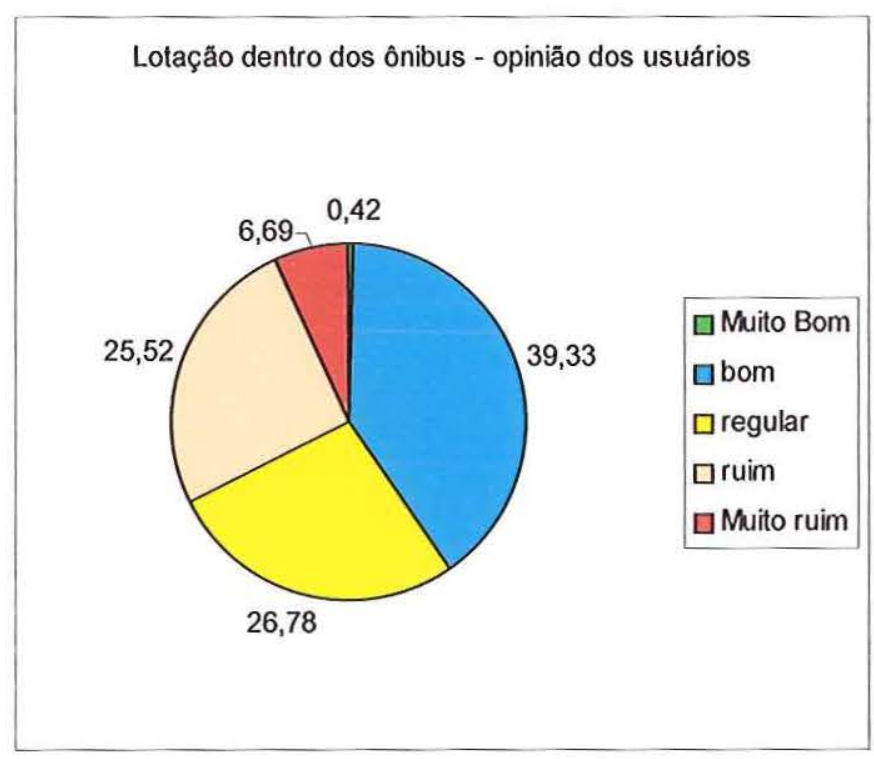

Figura 4 - Lotação dentro dos ônibus 


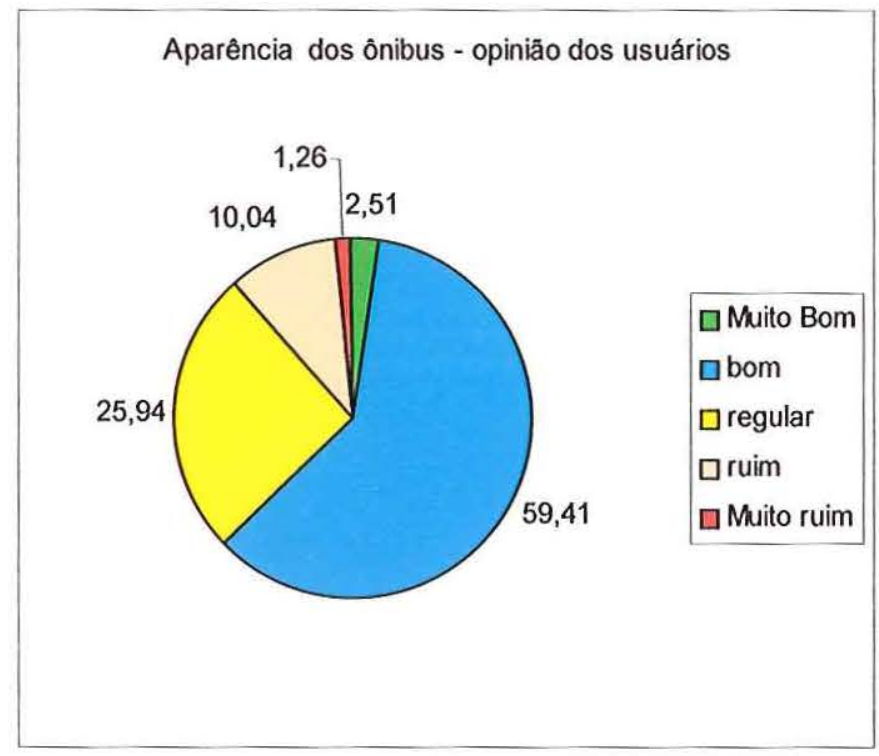

Figura 5 - Aparência dos ônibus

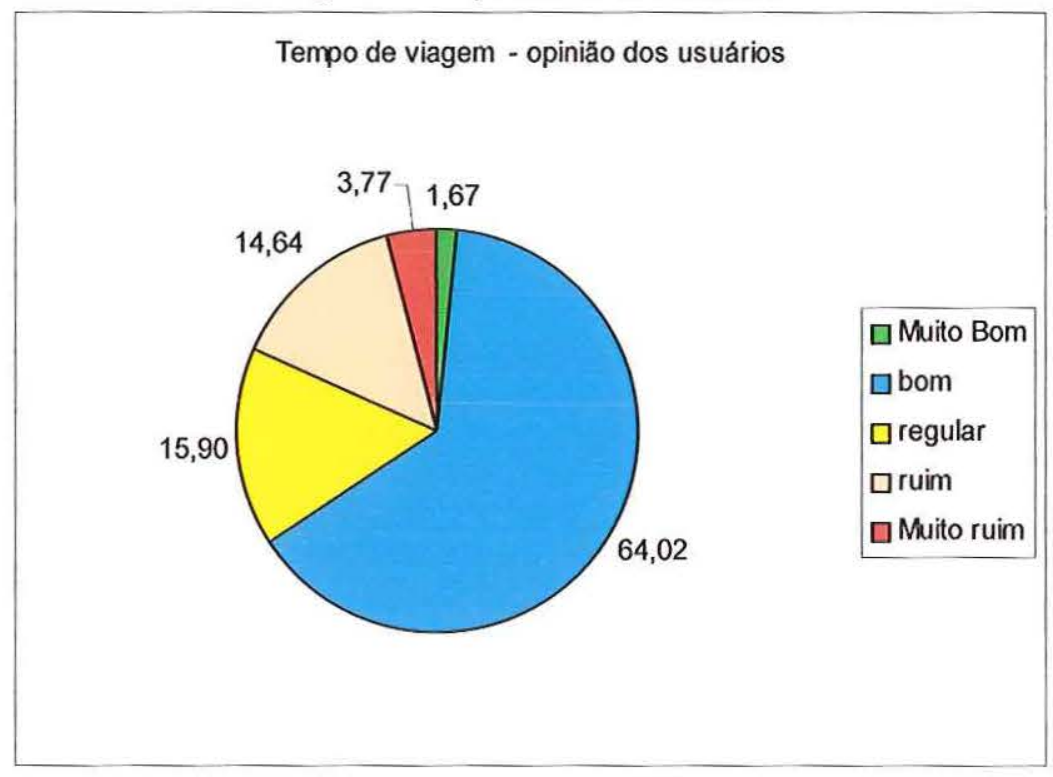

Figura 6 - Tempo de Viagem 


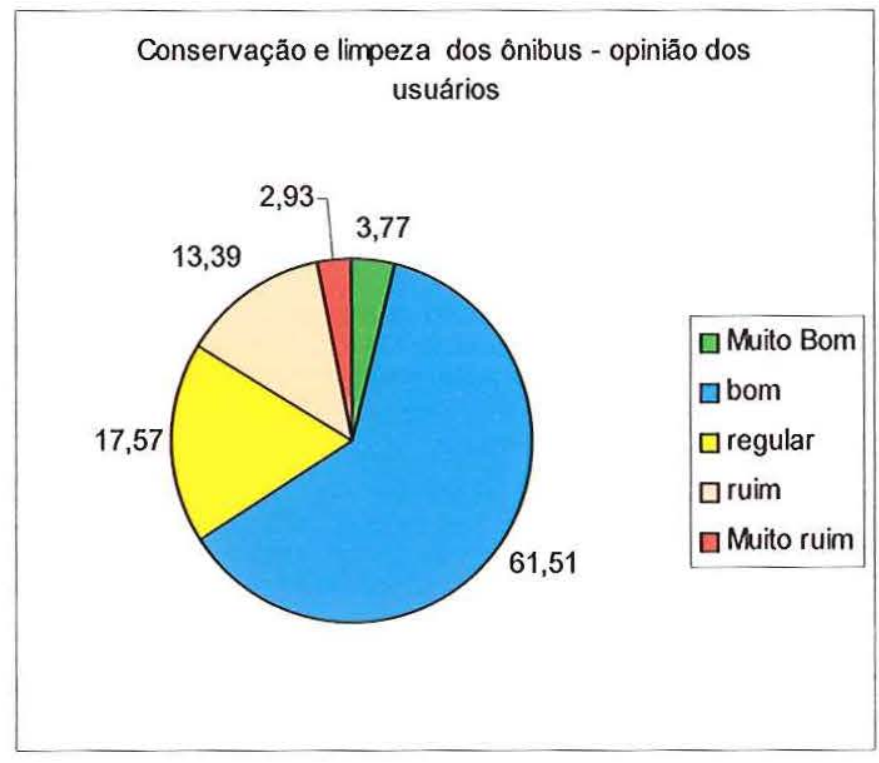

Figura 7 - Conservação e limpeza dos ônibus

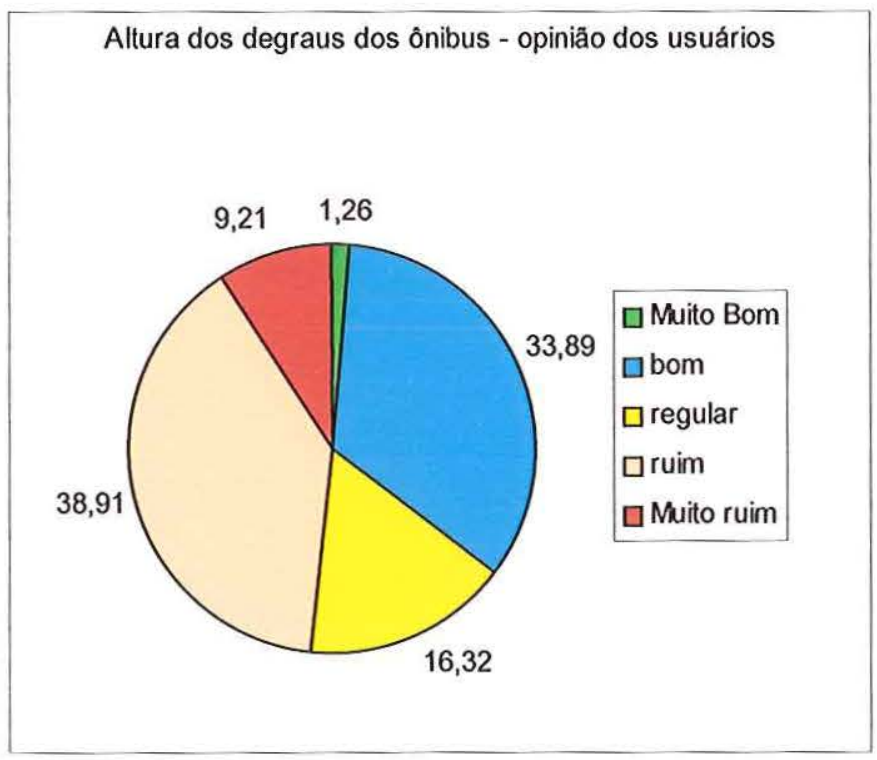

Figura 8 - Altura dos degraus dos ônibus 


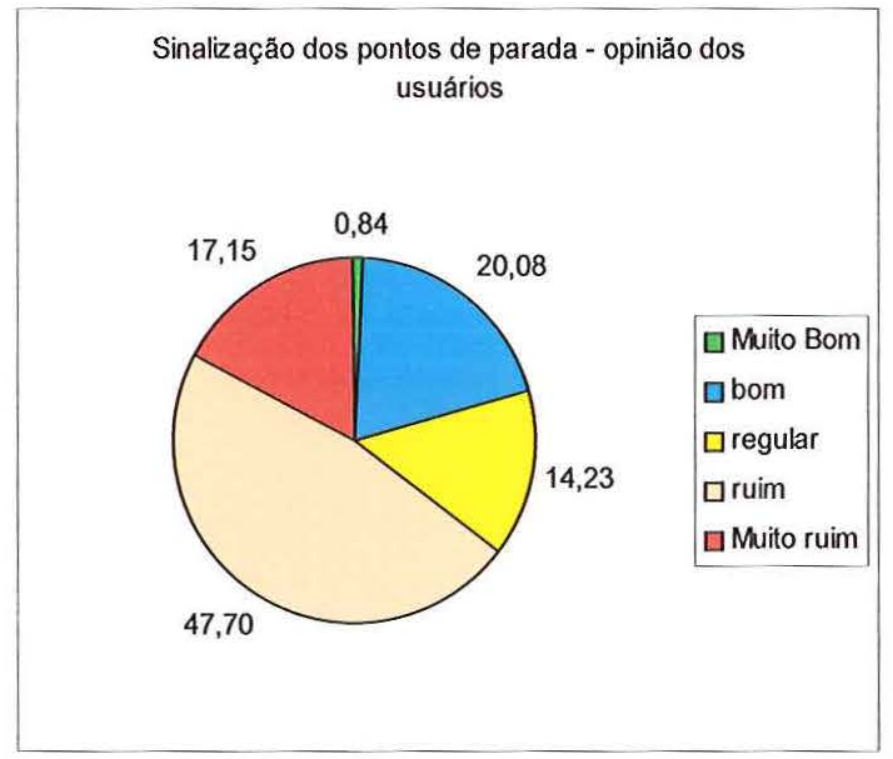

Figura 9 - Sinalização dos pontos de parada

Abrigo nos pontos de parada - opinião dos usuários

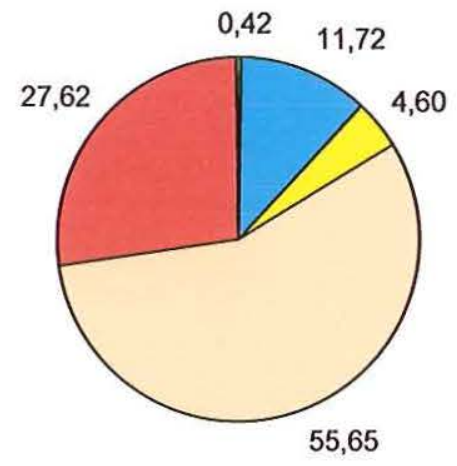

\begin{tabular}{|l}
$\square$ Muito Bom \\
$\square$ bom \\
$\square$ regular \\
$\square$ ruim \\
$\square$ Muito ruim
\end{tabular}

Figura 10 - Abrigo nos pontos de parada 


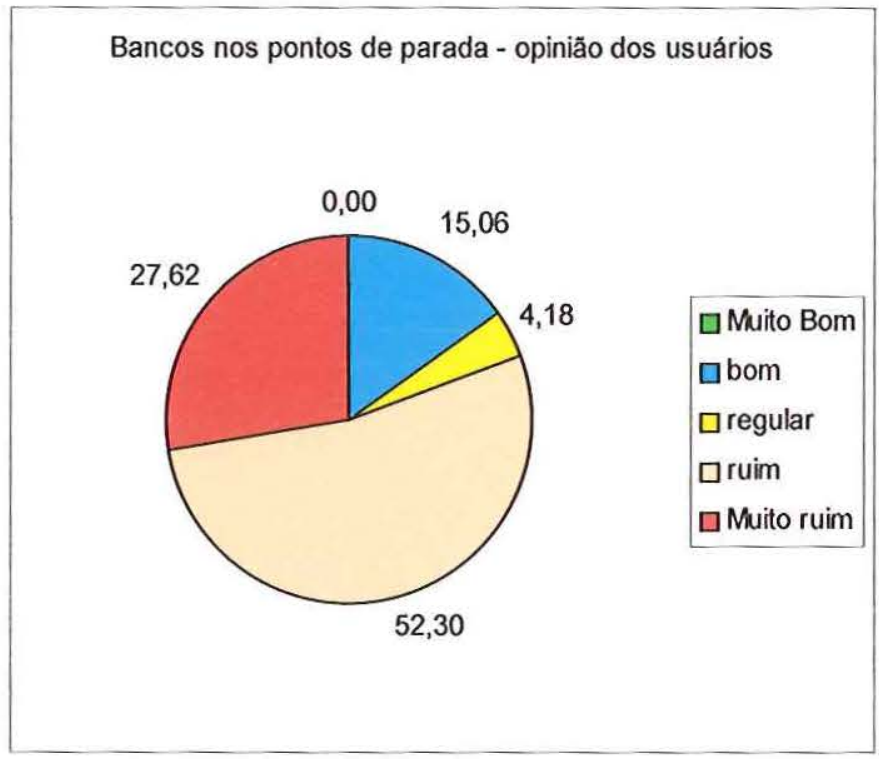

Figura 11 - Bancos nos pontos de parada

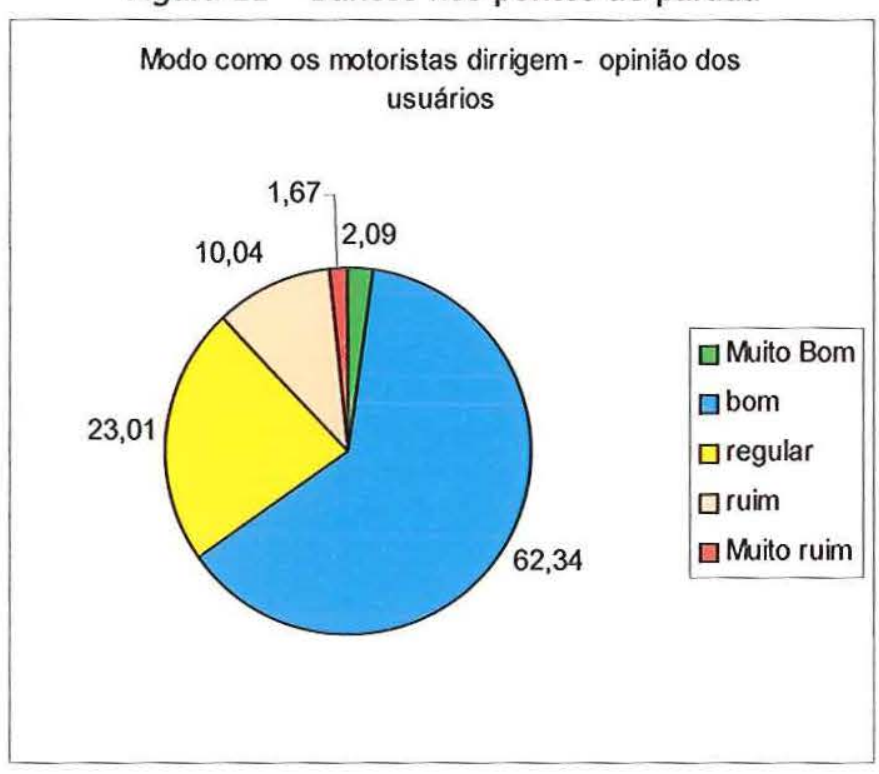

Figura 12 - Modo como os motoristas dirigem 


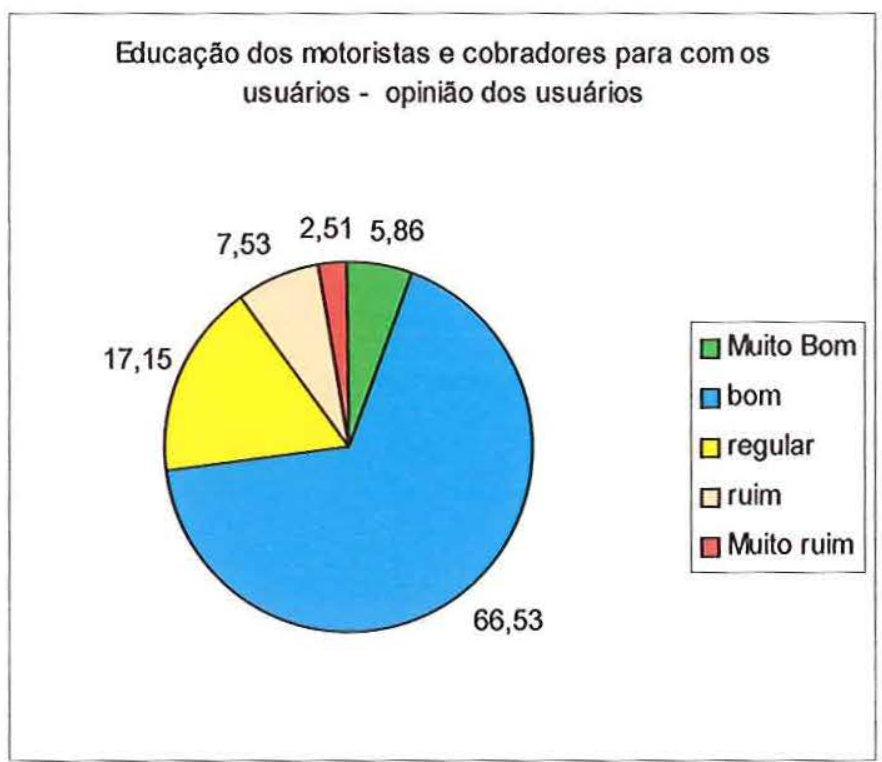

Figura 13 - Educação dos motoristas e cobradores para com os usuários

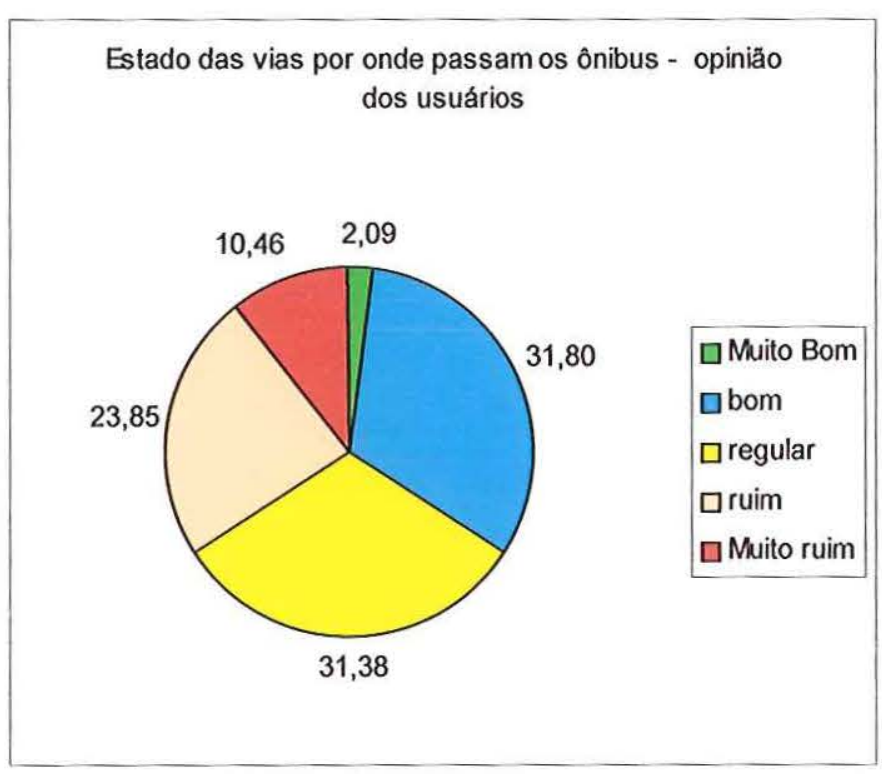

Figura 14 - Estado das vias por onde passam os ônibus 


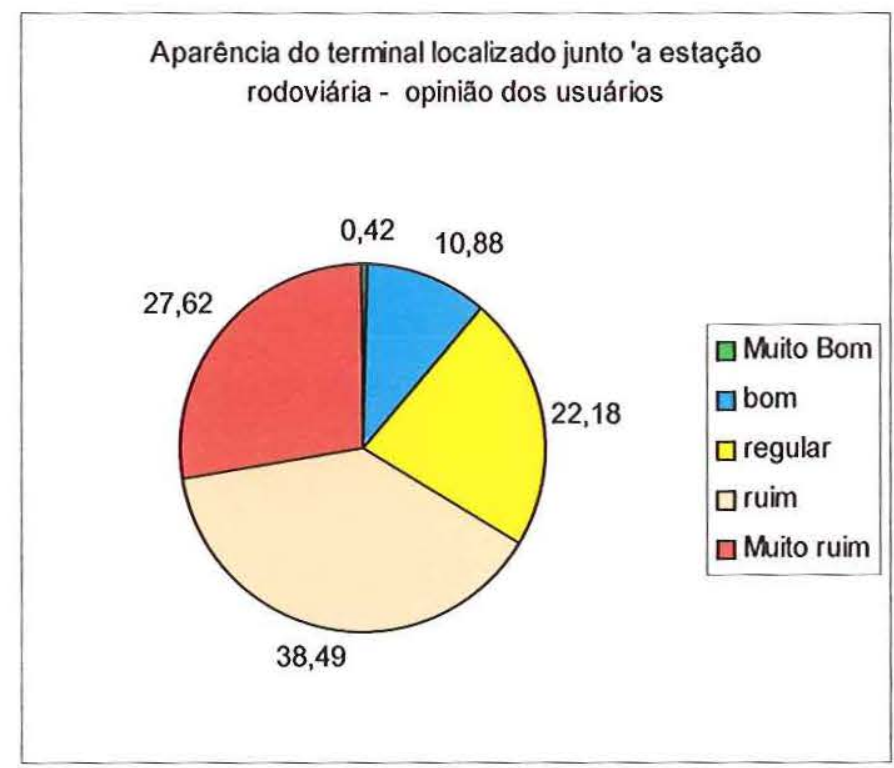

Figura 15 - Aparência do terminal localizado junto 'a estação rodoviária

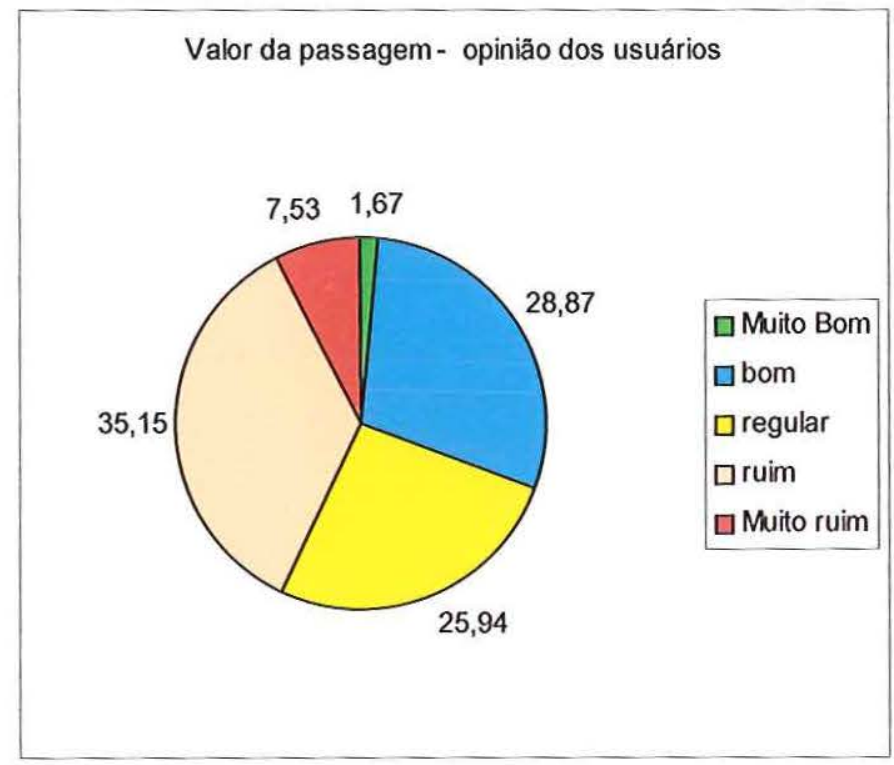

Figura 16 - Valor da passagem 


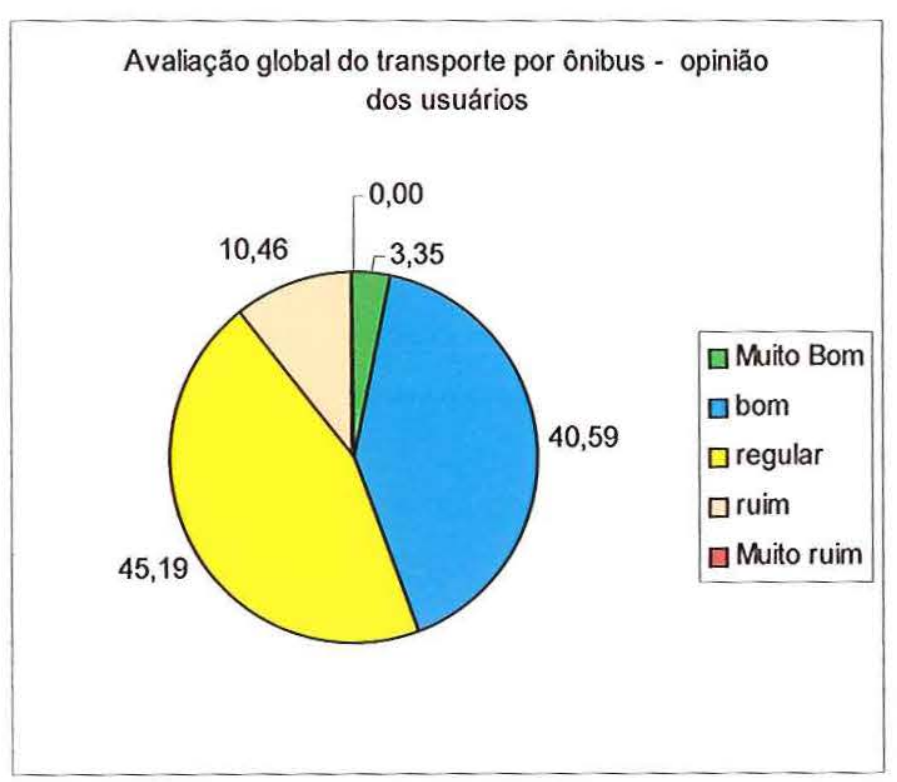

Figura 17 - Avaliação global do transporte por ônibus 


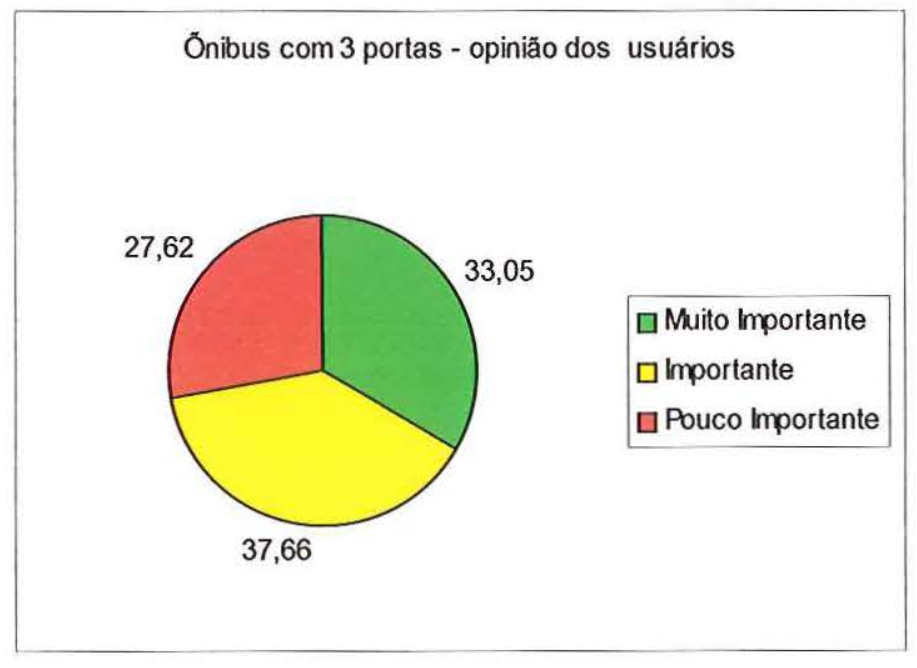

Figura 1 - Ônibus com 3 portas

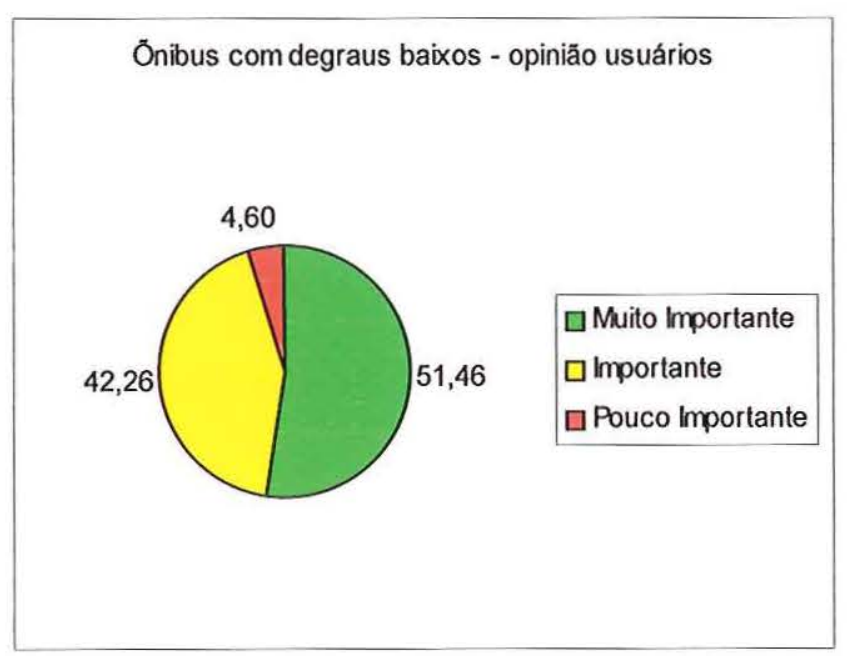

Figura 2 - Ônibus com degraus baixos 


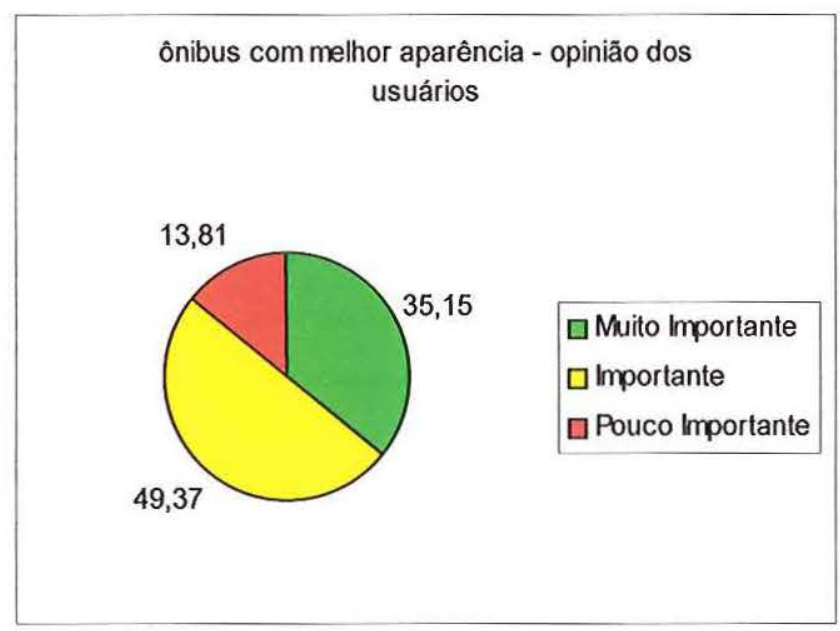

Figura 3 - Ônibus com melhor aparência

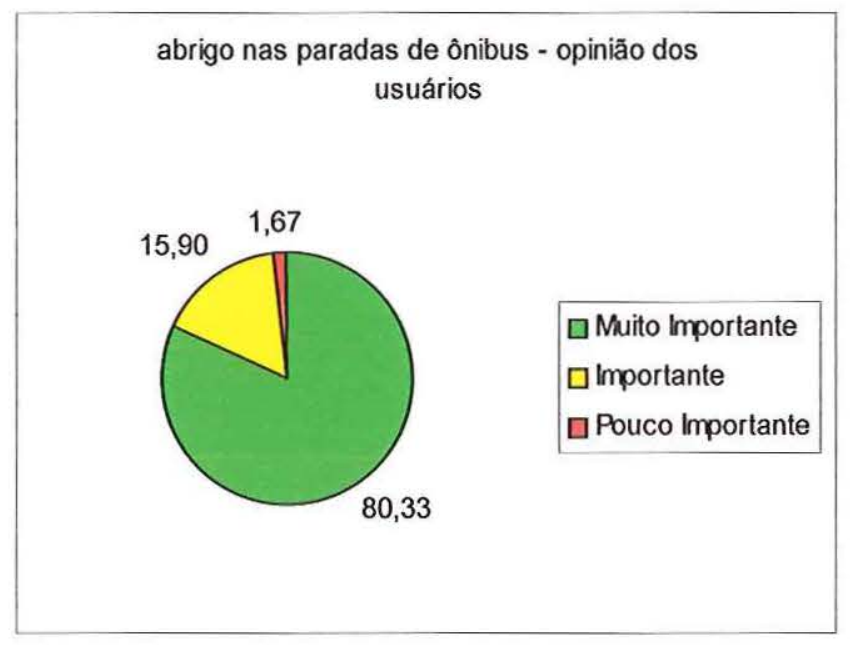

Figura 4 - Abrigo nas paradas de ônibus

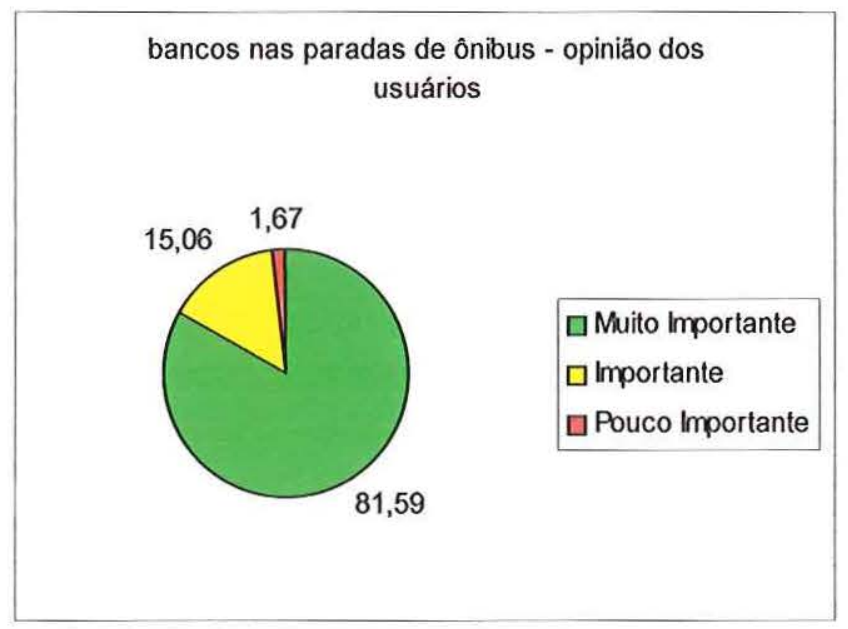

Figura 5 - Bancos nas paradas de ônibus 


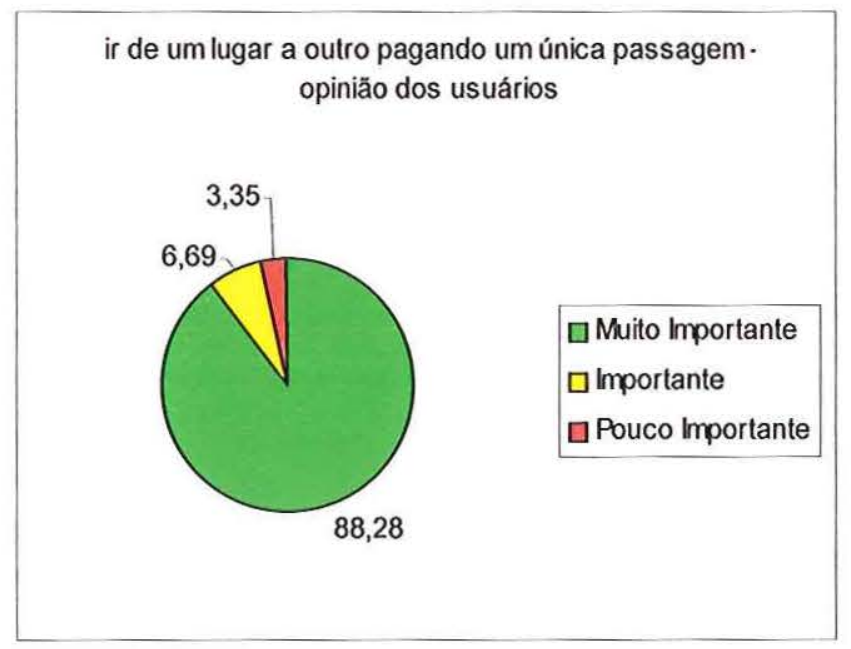

Figura 6 - Ir de um lugar a outro pagando uma única passagem

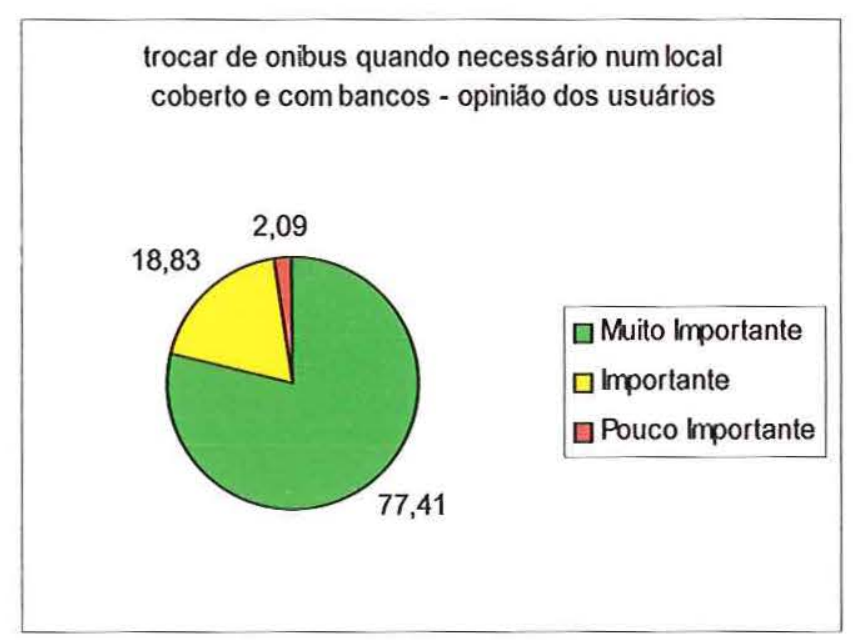

Figura 7 - Trocar de ônibus quando necessário num local coberto e com bancos 


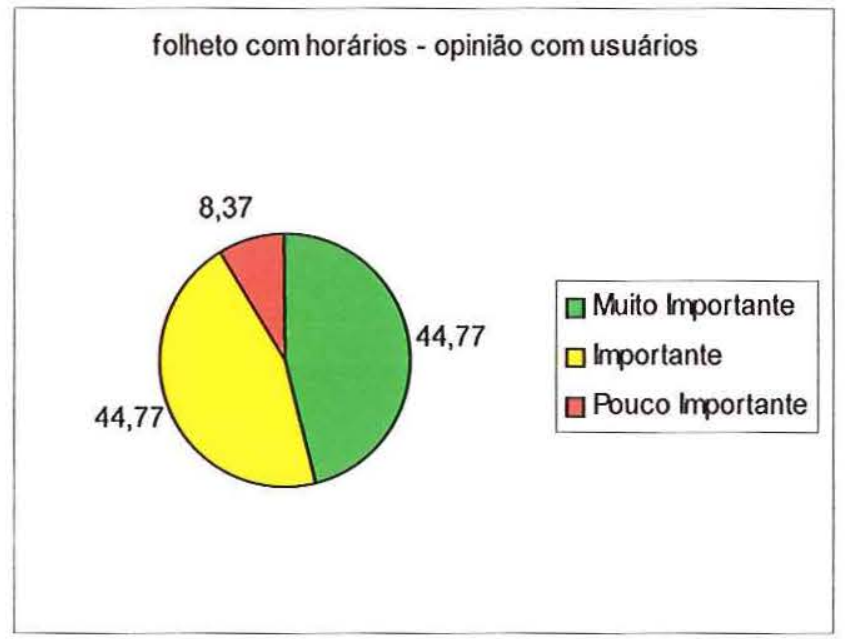

Figura 8 - Folheto com horários

folheto com mapa das linhas - opinião dos usuários

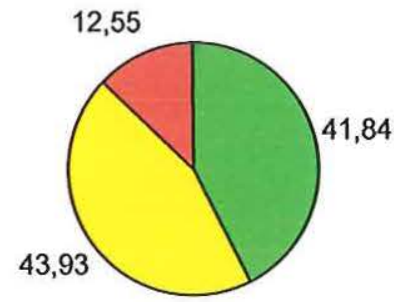

$\square$ Muito Importante $\square$ Importante

$\square$ Pouco Importante

Figura 9 - Folheto com mapa das linhas 


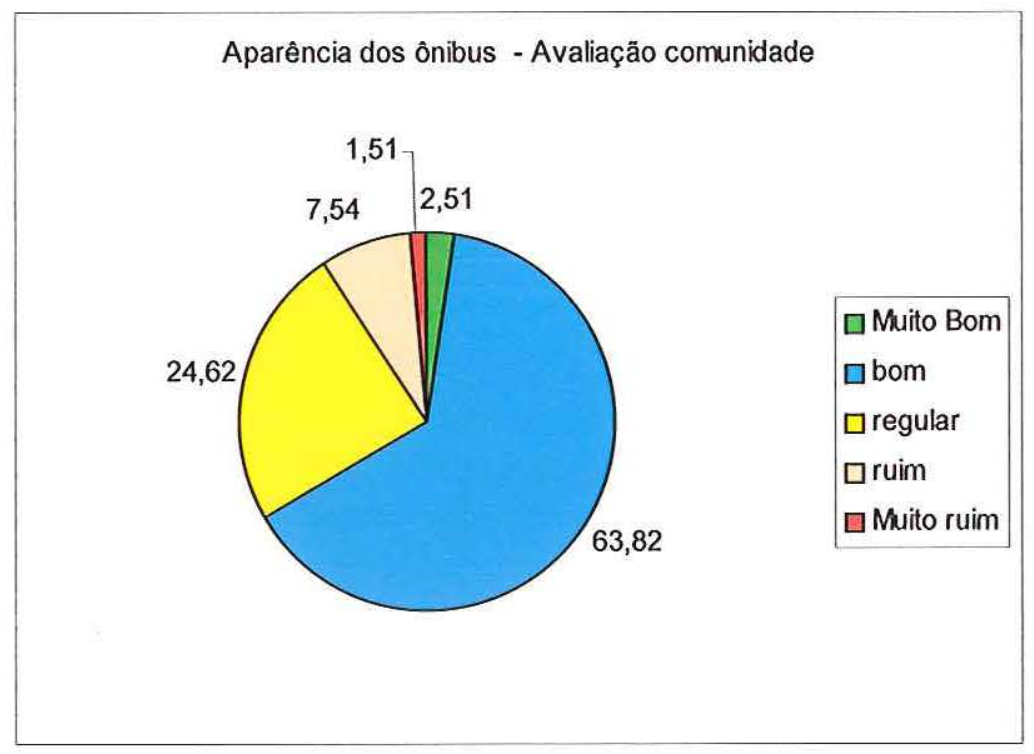

Figura 1 - Aparência dos ônibus

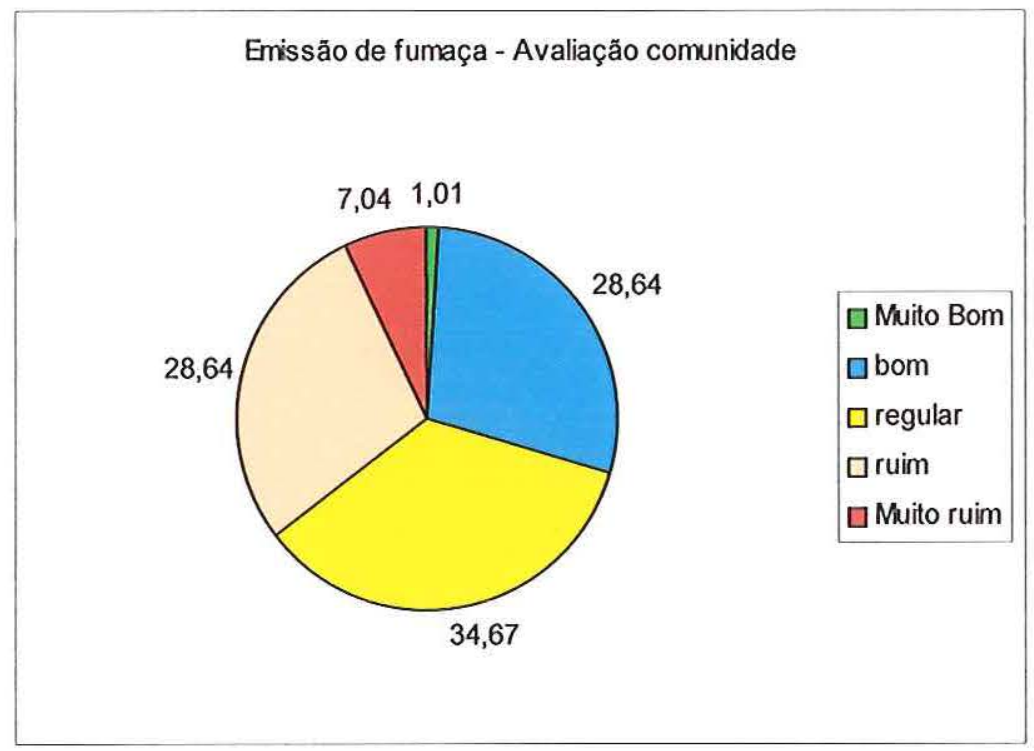

Figura 2 - Emissão de fumaça 


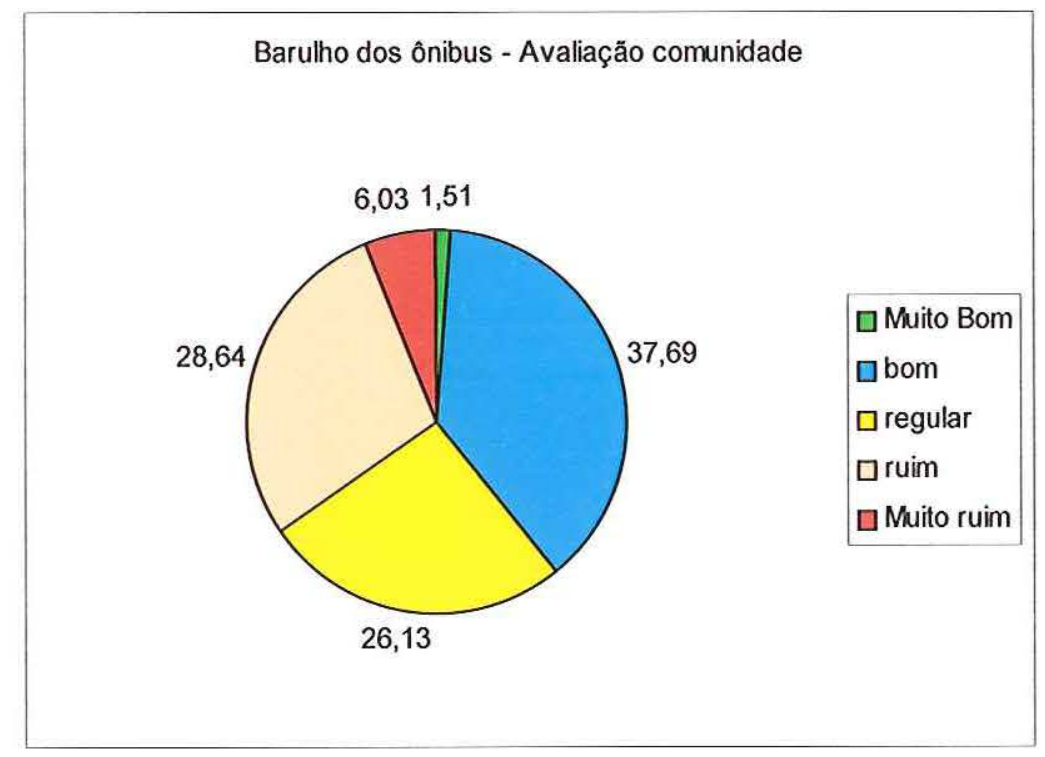

Figura 3 - Barulho dos ônibus

Aparência das paradas de ônibus - Avaliação comunidade

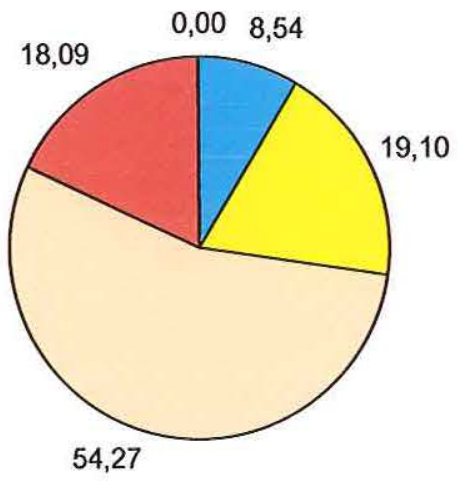

$\square$ Muito Bom

$\square$ bom

$\square$ regular

$\square$ ruim

$\square$ Muito ruim

Figura 4 - Aparência das paradas de ônibus 


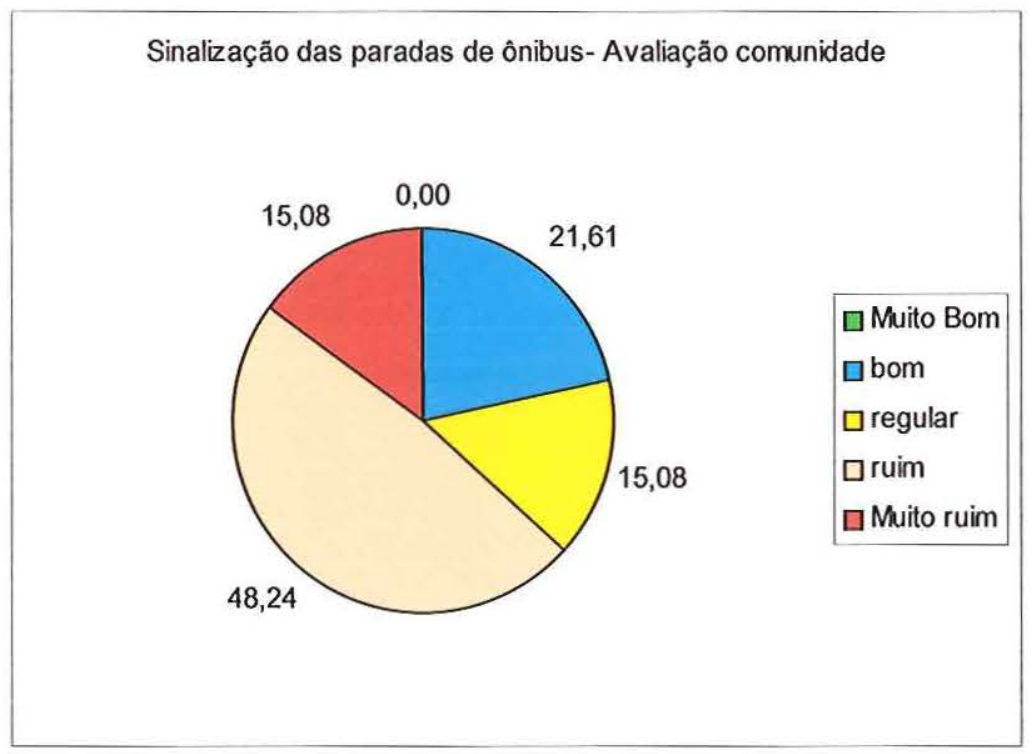

Figura 5 - Sinalização das paradas de ônibus

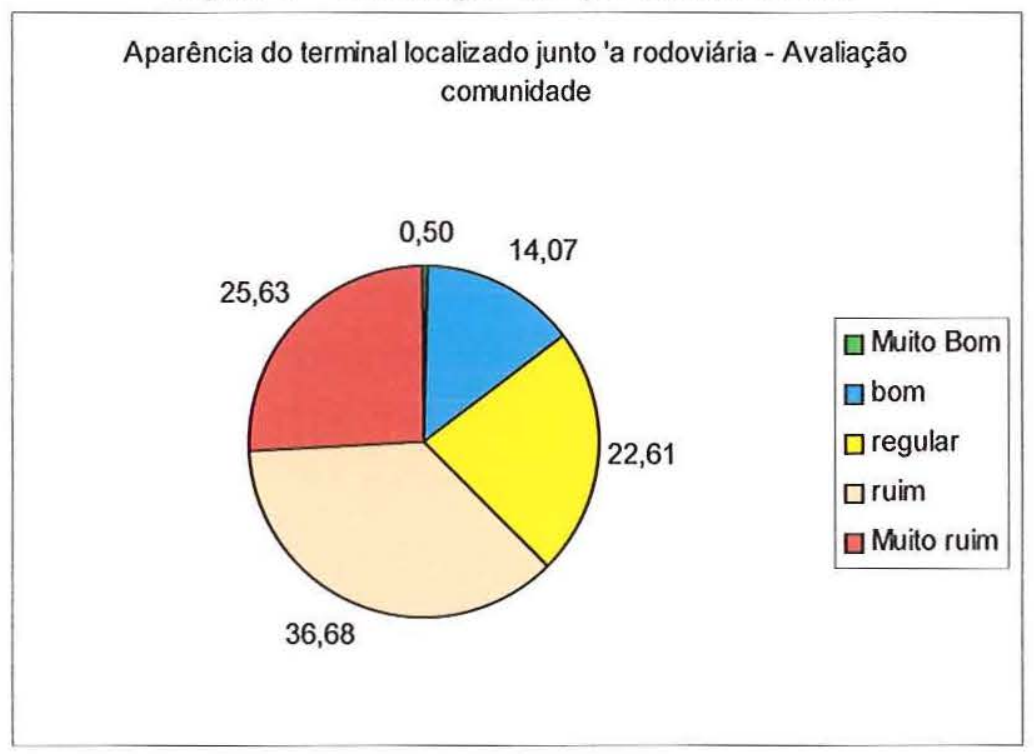

Figura 6 - Aparência do terminal localizado junto 'a rodoviária 


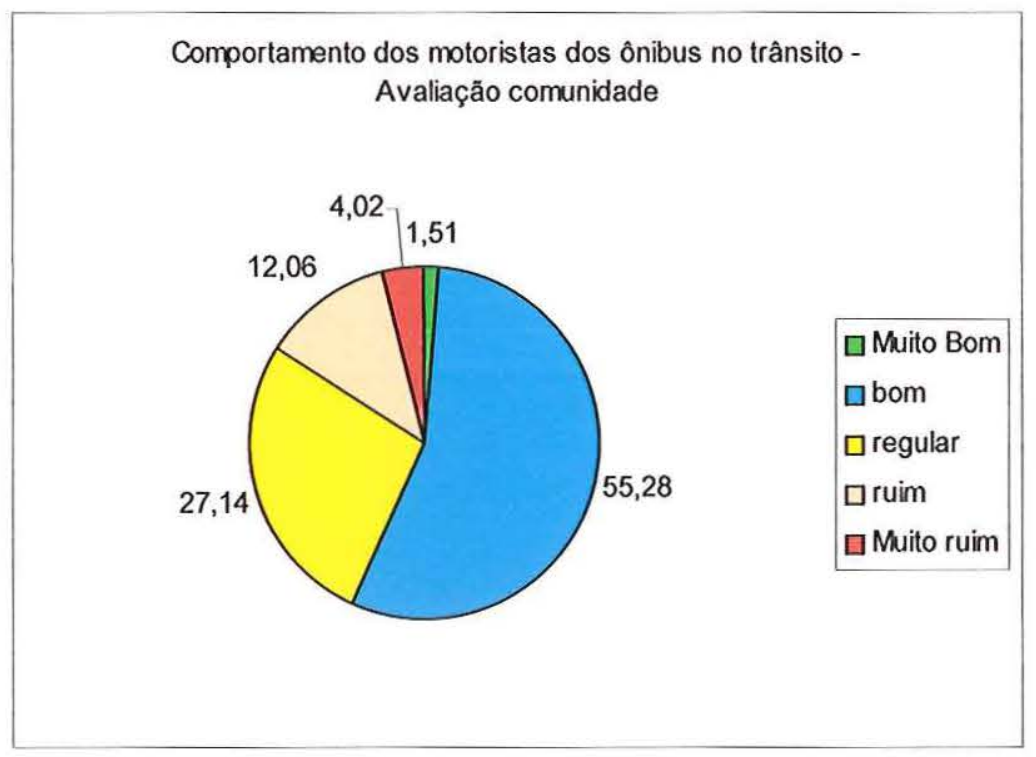

Figura 7 - Comportamento dos motoristas dos ônibus no trânsito

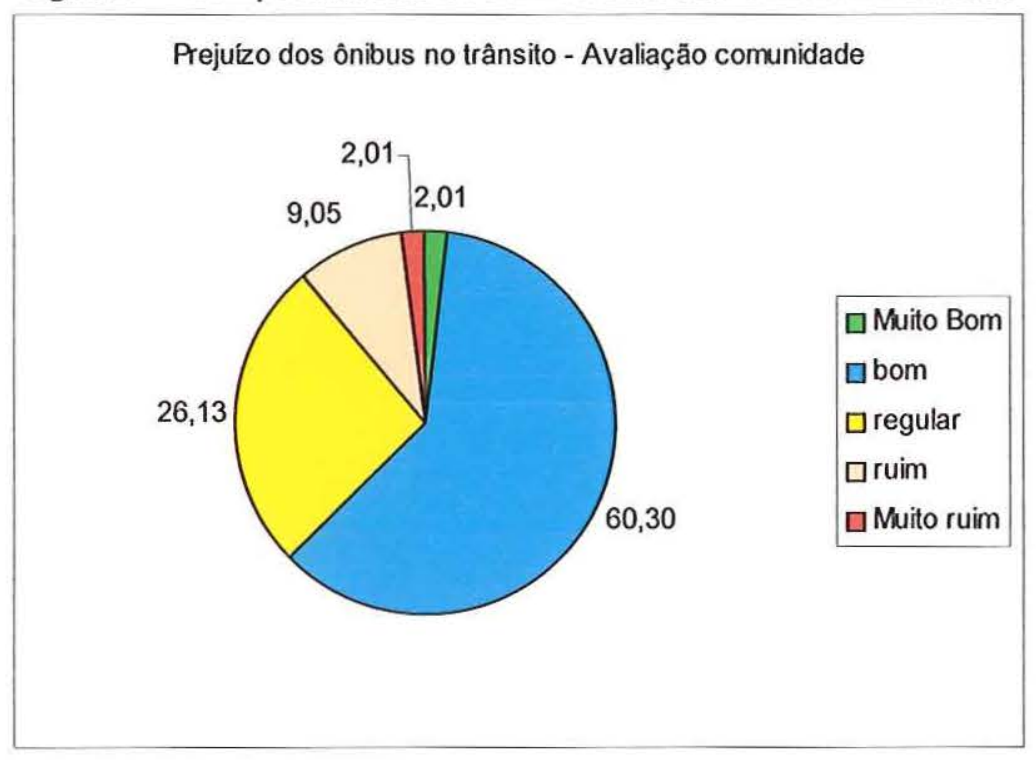

Figura 8 - Prejuízo dos ônibus no trânsito 


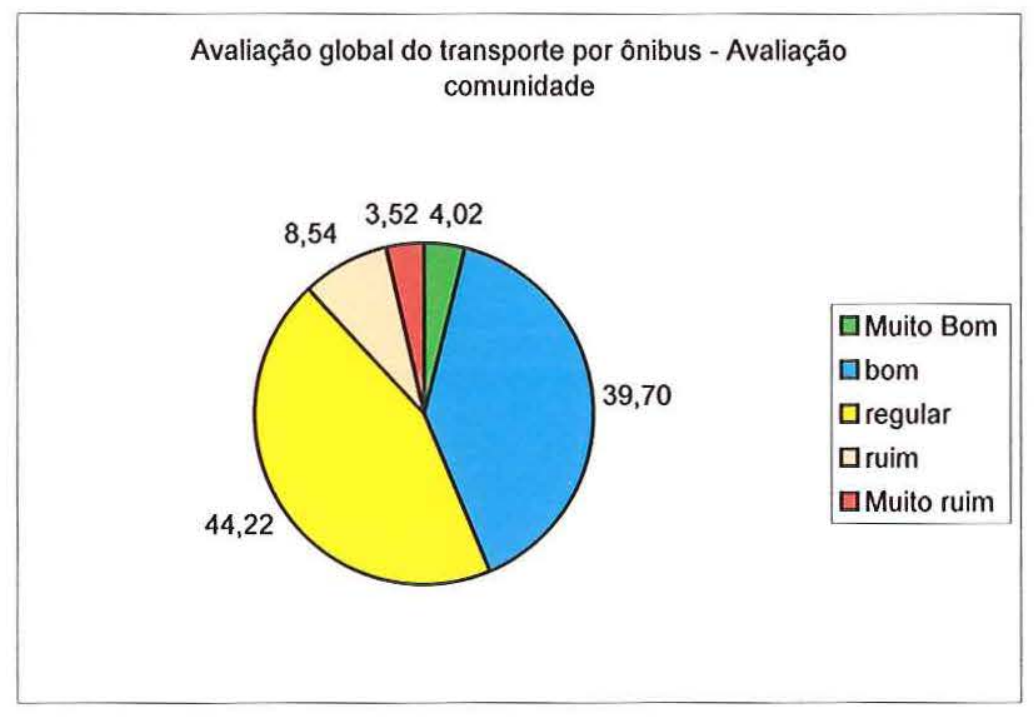

Figura 9 - Avaliação global do transporte por ônibus 
Figura 1 - Ônibus com degraus baixos

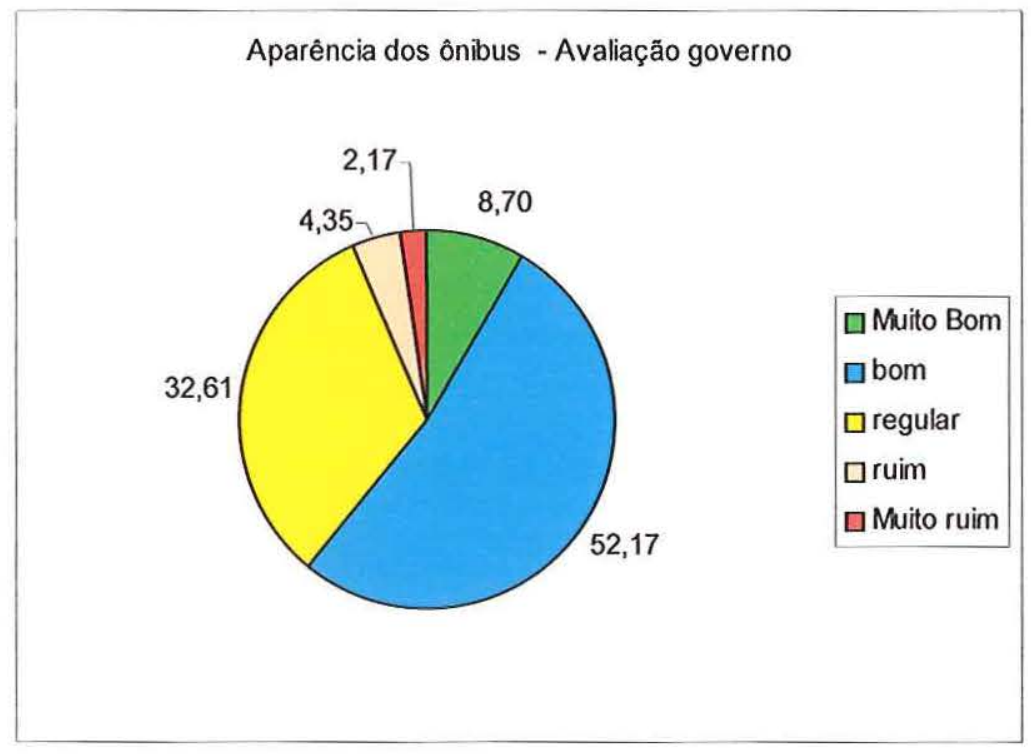

Figura 2 - Aparência dos ônibus

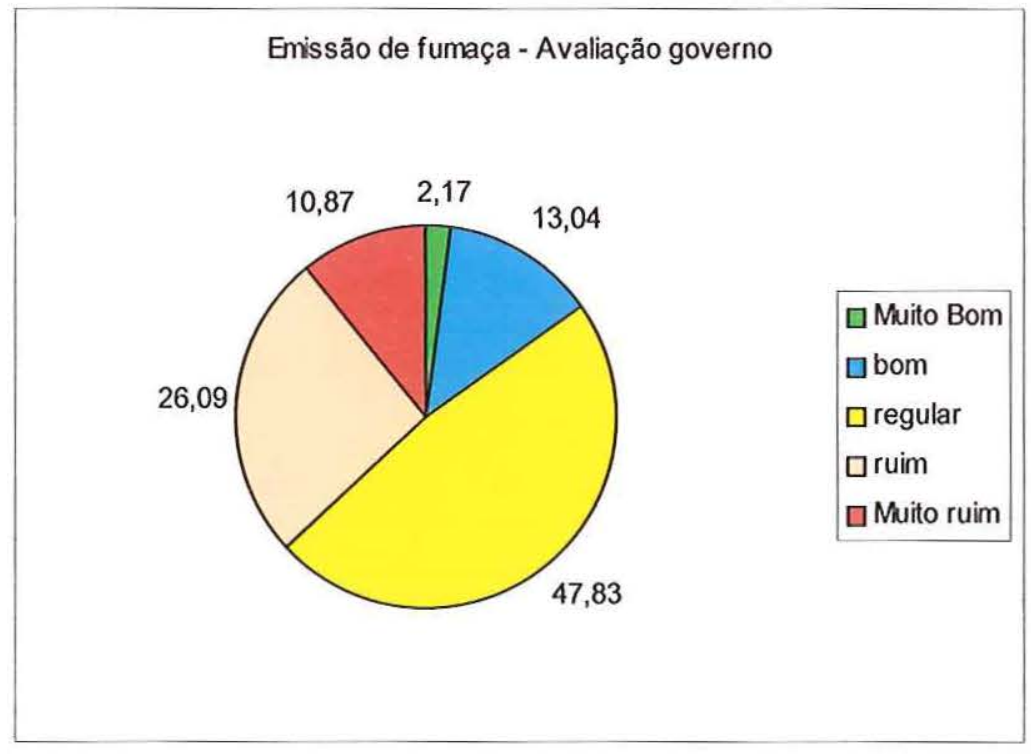

Figura 3 - Emissão de fumaça 


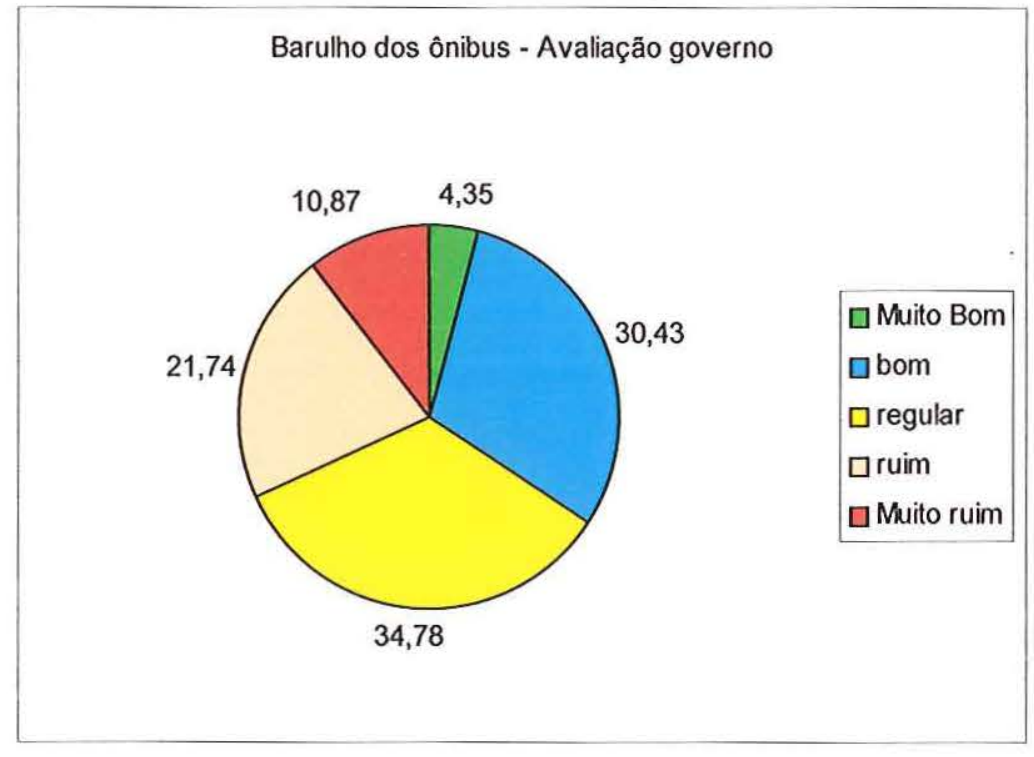

Figura 4-Barulho dos ônibus

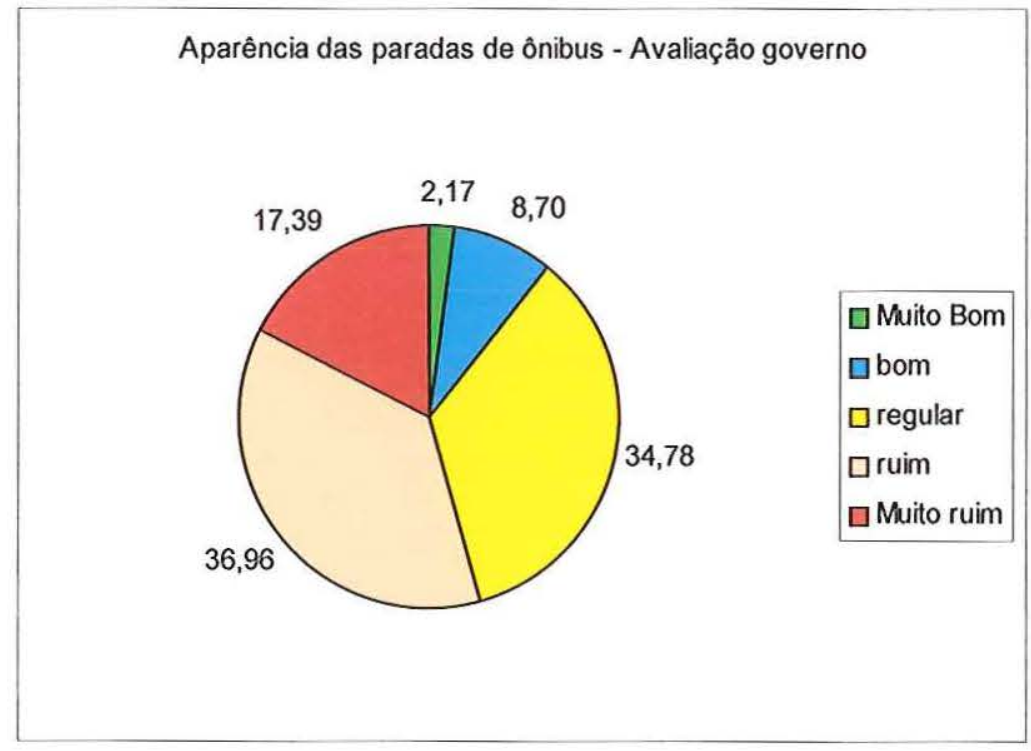

Figura 5 - Aparência das paradas de ônibus 


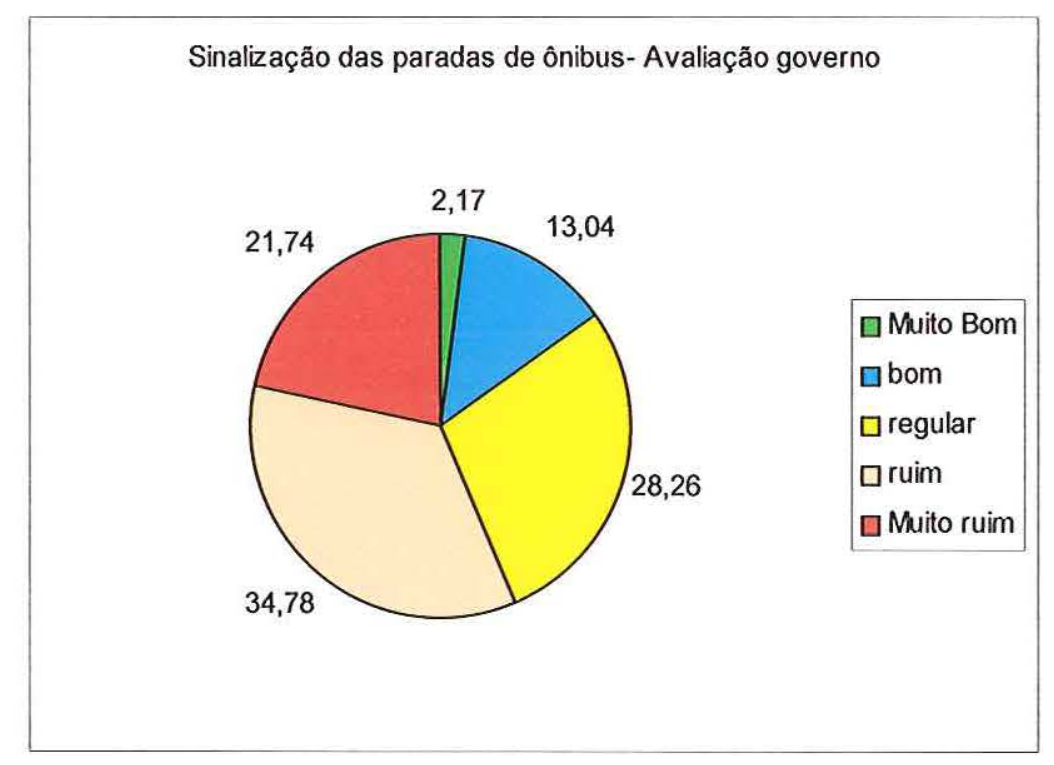

Figura 6 - Sinalização das paradas de ônibus

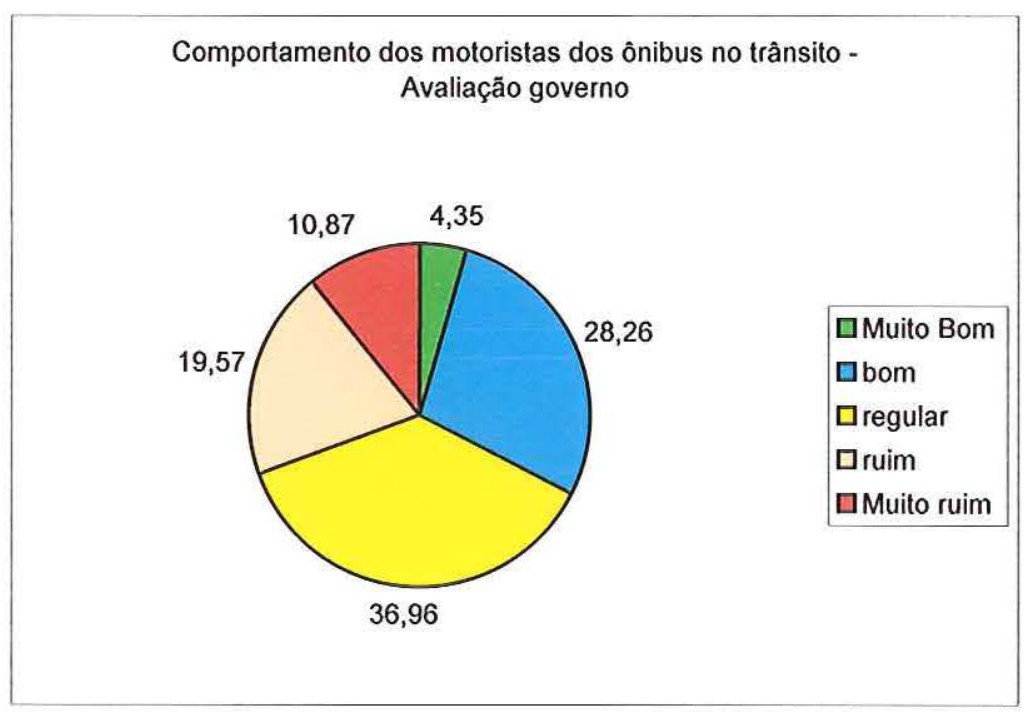

Figura 7 - Comportamento dos motoristas dos ônibus no trânsito 


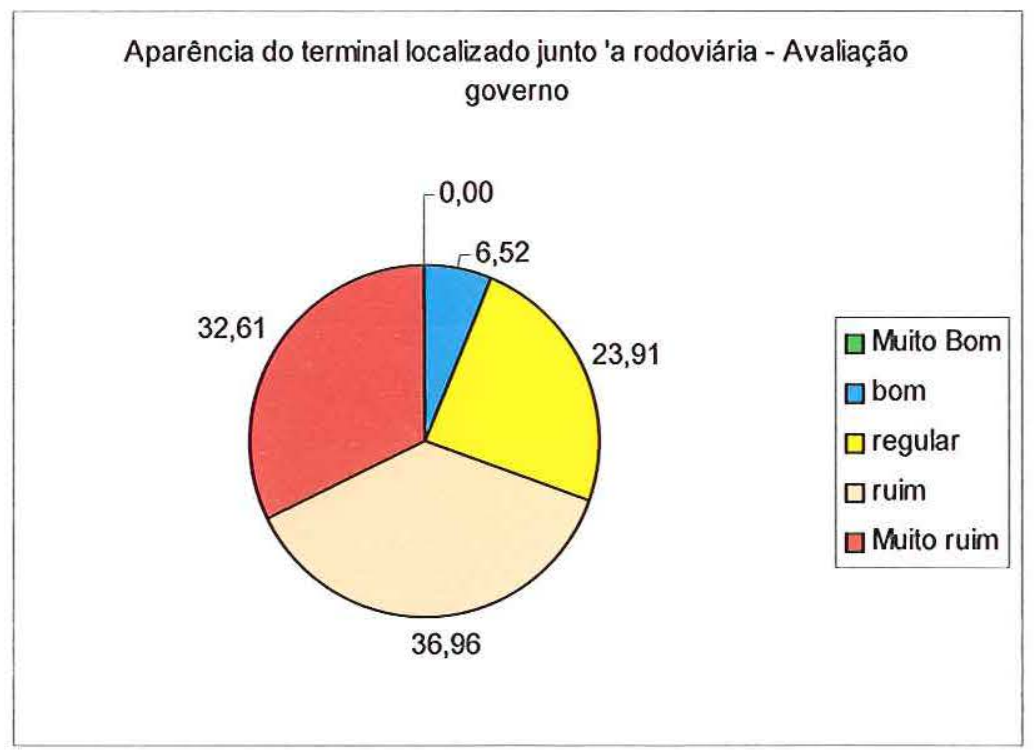

Figura 8 - Aparência do terminal localizado junto 'a rodoviária

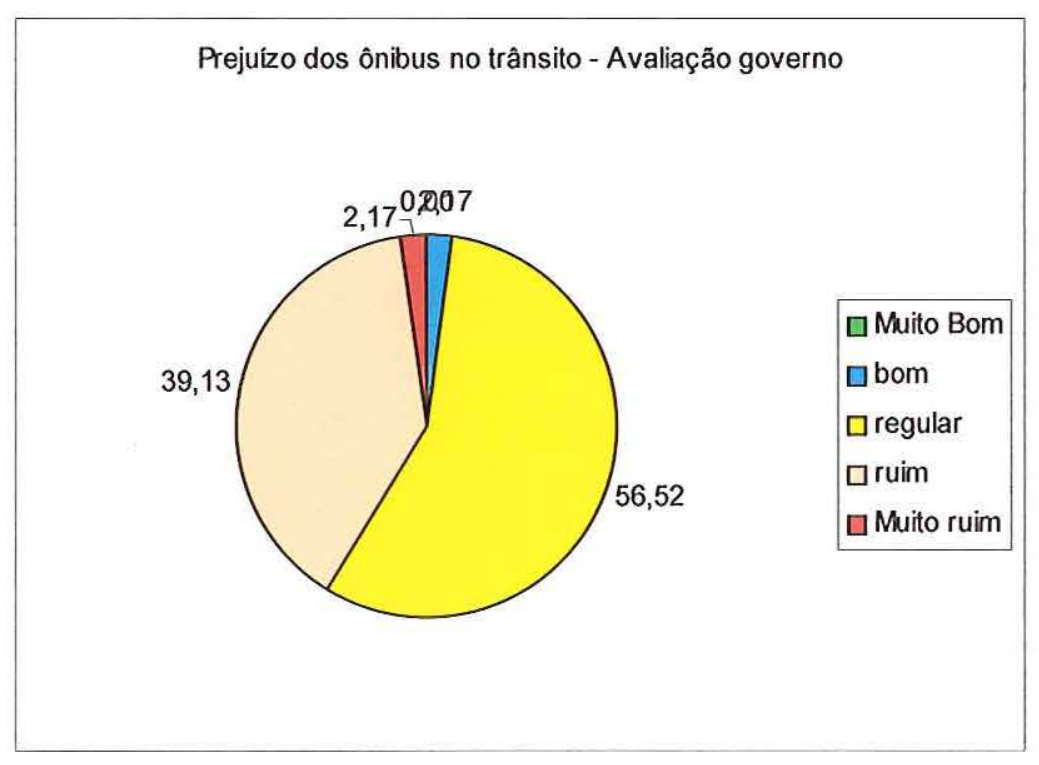

Figura 9 - Prejuízo dos ônibus no trânsito

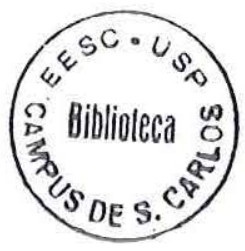




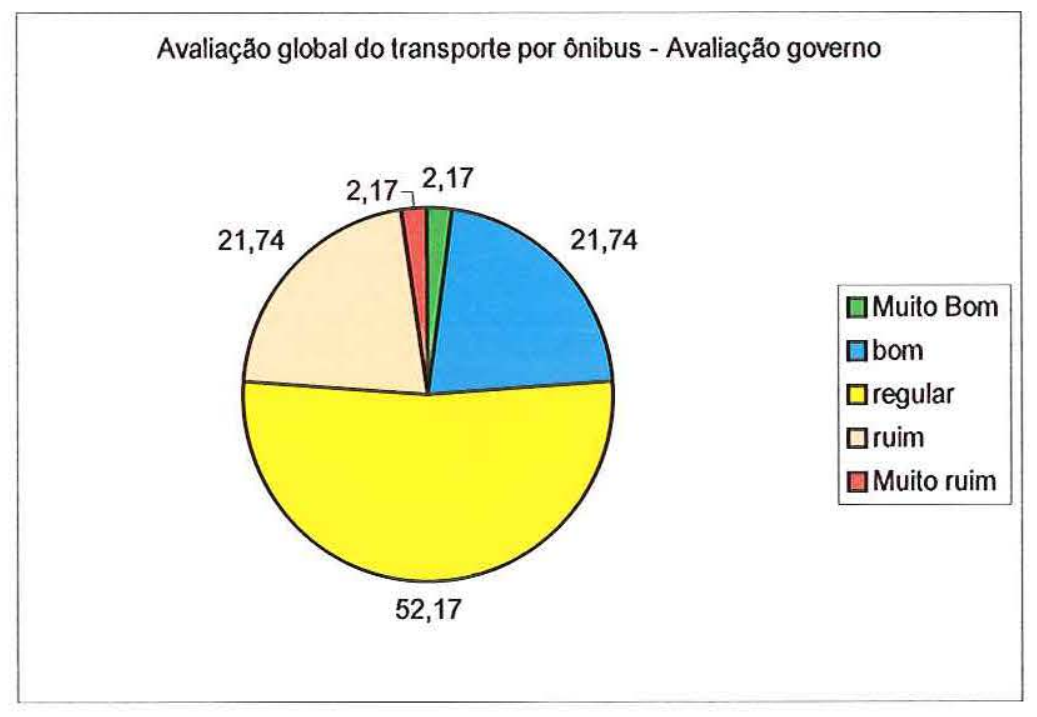

Figura 10 - Avaliação global do transporte por ônibus 


\section{Usuário}

\section{PESQUISA SOBRE O TRANSPORTE COLETIVO POR ÔNIBUS}

idade:

sexo: ( ) feminino ( ) masculino

grau de instrução:

\begin{tabular}{|c|c|c|c|c|c|}
\hline $\begin{array}{l}\text { Como você classifica os seguintes aspectos relacionados à qualidade de } \\
\text { transporte por ônibus? }\end{array}$ & $\begin{array}{l}\text { Muito } \\
\text { bom }\end{array}$ & Bom & Regular & Ruim & $\begin{array}{l}\text { Muito } \\
\text { ruim }\end{array}$ \\
\hline 1- Distância percorrida à pé para usar os ônibus. & 4,18 & 68,20 & 8,79 & 15,90 & 2,51 \\
\hline 2- Intervalo entre a passagem dos ônibus. & 1,26 & 44,77 & 16,32 & 30,54 & 6,69 \\
\hline 3- Tempo de viagem dentro do ônibus. & 1,67 & 64,02 & 15,9 & 14,64 & 3,77 \\
\hline 4- Cumprimento dos horários. & 4,18 & 46,44 & 21,76 & 22,59 & 4,60 \\
\hline 5- Lotação (número de pessoas) dentro dos ônibus. & 0,42 & 39,33 & 26,78 & 25,52 & 6,69 \\
\hline 6- Aparência dos ônibus. & 2,51 & 59,41 & 25,94 & 10,04 & 1,26 \\
\hline 7- Altura dos degraus do ônibus. & 1,26 & 33,89 & 16,32 & 38,91 & 9,21 \\
\hline 8- Conservação e limpeza dos ônibus. & 3,77 & 61,51 & 17,57 & 13,39 & 2,93 \\
\hline 9- Sinalização dos pontos de parada. & 0,84 & 20,08 & 14,23 & 47,70 & 17,15 \\
\hline 10- Abrigo nos pontos de parada. & 0,42 & 11,72 & 4,60 & 55,65 & 27,62 \\
\hline 11- Banco nos pontos de parada. & 0 & 15,06 & 4,18 & 52,30 & 27,62 \\
\hline 12- Modo como os motoristas dirigem. & 2,09 & 62,34 & 23,01 & 10,04 & 1,67 \\
\hline 13- Educação dos motoristas e cobradores para com os usuários. & 5,86 & 66,53 & 17,15 & 7,53 & 2,51 \\
\hline 14- Estado das vias por onde passam os ônibus. & 2,09 & 31,8 & 31,38 & 23,85 & 10,46 \\
\hline 15- Aparência do terminal localizado junto à estação rodoviária. & 0,42 & 10,88 & 22,18 & 38,49 & 27,62 \\
\hline 16- Valor da passagem. & 1,67 & 28,87 & 25,94 & 35,15 & 7,53 \\
\hline 17- Avaliação global do transporte por ônibus. & 3,35 & 40,59 & 45,19 & 10,46 & 0,00 \\
\hline
\end{tabular}


Usuário

\begin{tabular}{|c|c|c|c|}
\hline Como você classifica os seguintes aspectos no transporte por ônibus? & $\begin{array}{c}\text { Muito } \\
\text { importante }\end{array}$ & Importante & $\begin{array}{c}\text { Pouco } \\
\text { importante }\end{array}$ \\
\hline 1- Ônibus com 3 portas. & 33,05 & 37,66 & 27,62 \\
\hline 2-Ônibus com degraus baixos. & 51,46 & 42,26 & 4,60 \\
\hline 3- Ônibus com melhor aparência. & 35,15 & 49,37 & 13,81 \\
\hline 4- Abrigo nas paradas de ônibus. & 80,33 & 15,90 & 1,67 \\
\hline 5- Bancos nas paradas de ônibus. & 81,59 & 15,06 & 1,67 \\
\hline 6-Poder ir de um lugar a qualquer outro da cidade pagando uma única vez. & 88,28 & 6,69 & 3,35 \\
\hline 7- Trocar de ônibus quando necessário num local coberto e com bancos. & 77,41 & 18,83 & 2,09 \\
\hline 8- Folheto com os horários. & 44,77 & 44,77 & 8,37 \\
\hline 9- Folheto com o mapa das linhas. & 41,84 & 43,93 & 12,55 \\
\hline
\end{tabular}




\title{
Comunidade
}

\section{PESQUISA SOBRE O TRANSPORTE COLETIVO POR ÔNIBUS}

\author{
idade: \\ sexo: ( ) feminino ( ) masculino \\ grau de instrução:
}

\begin{tabular}{|c|c|c|c|c|c|}
\hline $\begin{array}{l}\text { Como você classifica os seguintes aspectos no transporte por } \\
\text { ônibus? }\end{array}$ & $\begin{array}{c}\text { Muito } \\
\text { bom }\end{array}$ & Bom & Regular & Ruim & Muito ruim \\
\hline \multicolumn{6}{|l|}{$1-$ Aparência dos ônibus } \\
\hline \multicolumn{6}{|l|}{2 - Emissão de fumaça } \\
\hline \multicolumn{6}{|l|}{ 3-Barulho dos ônibus } \\
\hline \multicolumn{6}{|l|}{ 4-Aparência das paradas de ônibus } \\
\hline \multicolumn{6}{|l|}{5 - Sinalização das paradas de ônibus } \\
\hline \multicolumn{6}{|l|}{ 6-Aparência do terminal localizado junto à rodoviária } \\
\hline \multicolumn{6}{|l|}{7 - Comportamento dos motoristas dos ônibus no trânsito } \\
\hline \multicolumn{6}{|l|}{8 - Prejuízo dos ônibus no trânsito } \\
\hline 9-Avaliação global do transporte por ônibus & & & & & \\
\hline
\end{tabular}




\section{PESQUISA SOBRE O TRANSPORTE COLETIVO POR ÔNIBUS}

\section{Governo}

\section{idade:}

sexo: ( ) feminino ( ) masculino

grau de instrução:

\begin{tabular}{|c|c|c|c|c|c|}
\hline $\begin{array}{l}\text { Como você classifica os seguintes aspectos no transporte por } \\
\text { ônibus? }\end{array}$ & $\begin{array}{l}\text { Muito } \\
\text { bom }\end{array}$ & Bom & Regular & Ruim & Muito ruim \\
\hline \multicolumn{6}{|l|}{$1-$ Aparência dos ônibus } \\
\hline \multicolumn{6}{|l|}{2 - Emissão de fumaça } \\
\hline \multicolumn{6}{|l|}{3 - Barulho dos ônibus } \\
\hline \multicolumn{6}{|l|}{4 - Aparência das paradas de ônibus } \\
\hline \multicolumn{6}{|l|}{5 - Sinalização das paradas de ônibus } \\
\hline \multicolumn{6}{|l|}{ 6- Aparência do terminal localizado junto à rodoviária } \\
\hline \multicolumn{6}{|l|}{ 7-Comportamento dos motoristas dos ônibus no trânsito } \\
\hline \multicolumn{6}{|l|}{8 - Prejuízo dos ônibus no trânsito } \\
\hline 9-Avaliação global do transporte por ônibus & & & & & \\
\hline
\end{tabular}


Anexo-9

"Mapa de análise dlo uso e ocupação do solo $\mathrm{x}$ rede de transporte público da cidade de Jaú" 


\section{Mapa de Análise do Uso e Ocupação do Solo x Rede de Transporte Público da Cidade de Jaú}

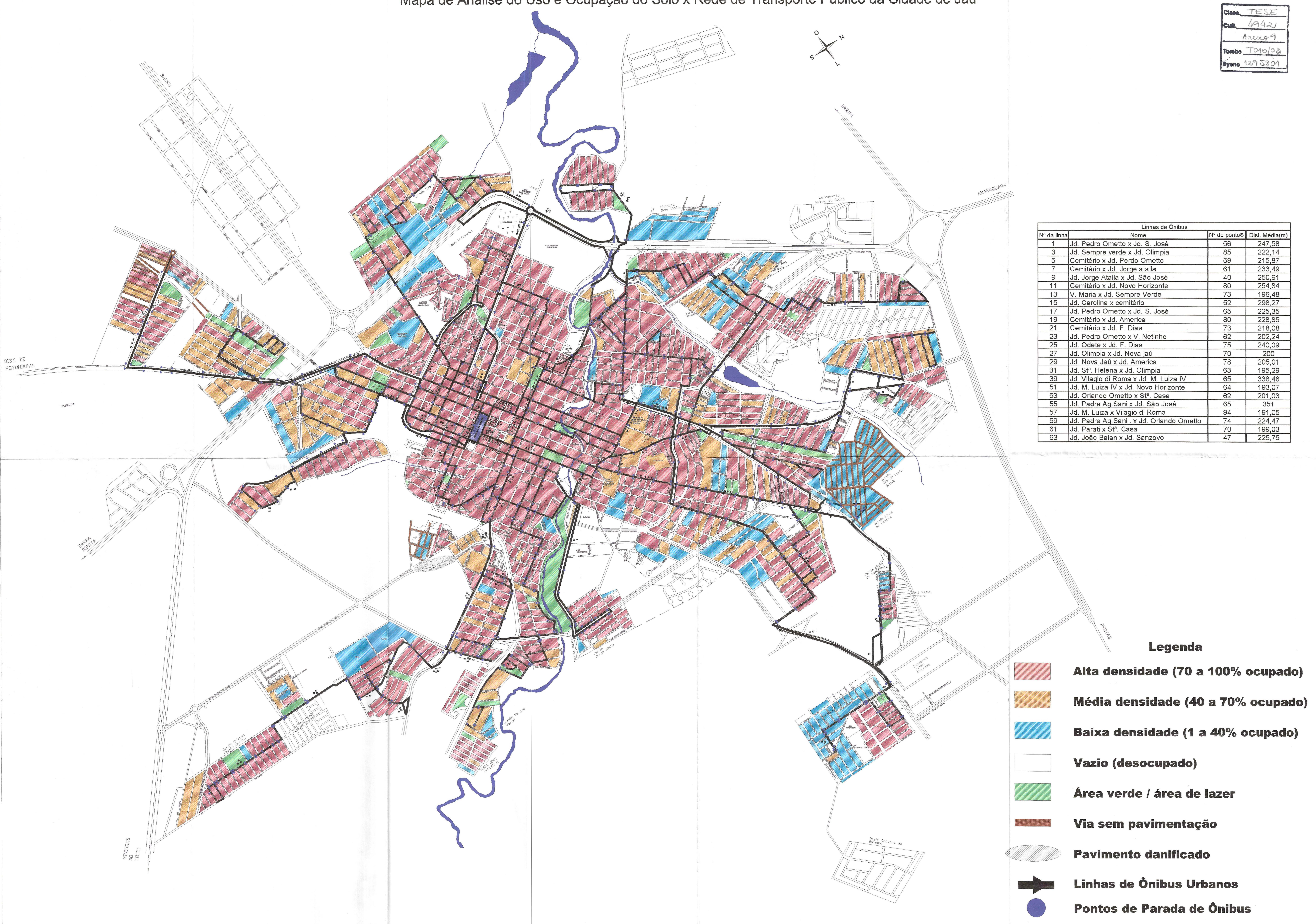


Anexo-10

"Mapa de análise da acessibilidade da rede de transporte público da cidade de Jaú $\mathrm{x}$ uso e ocupação do solo." 


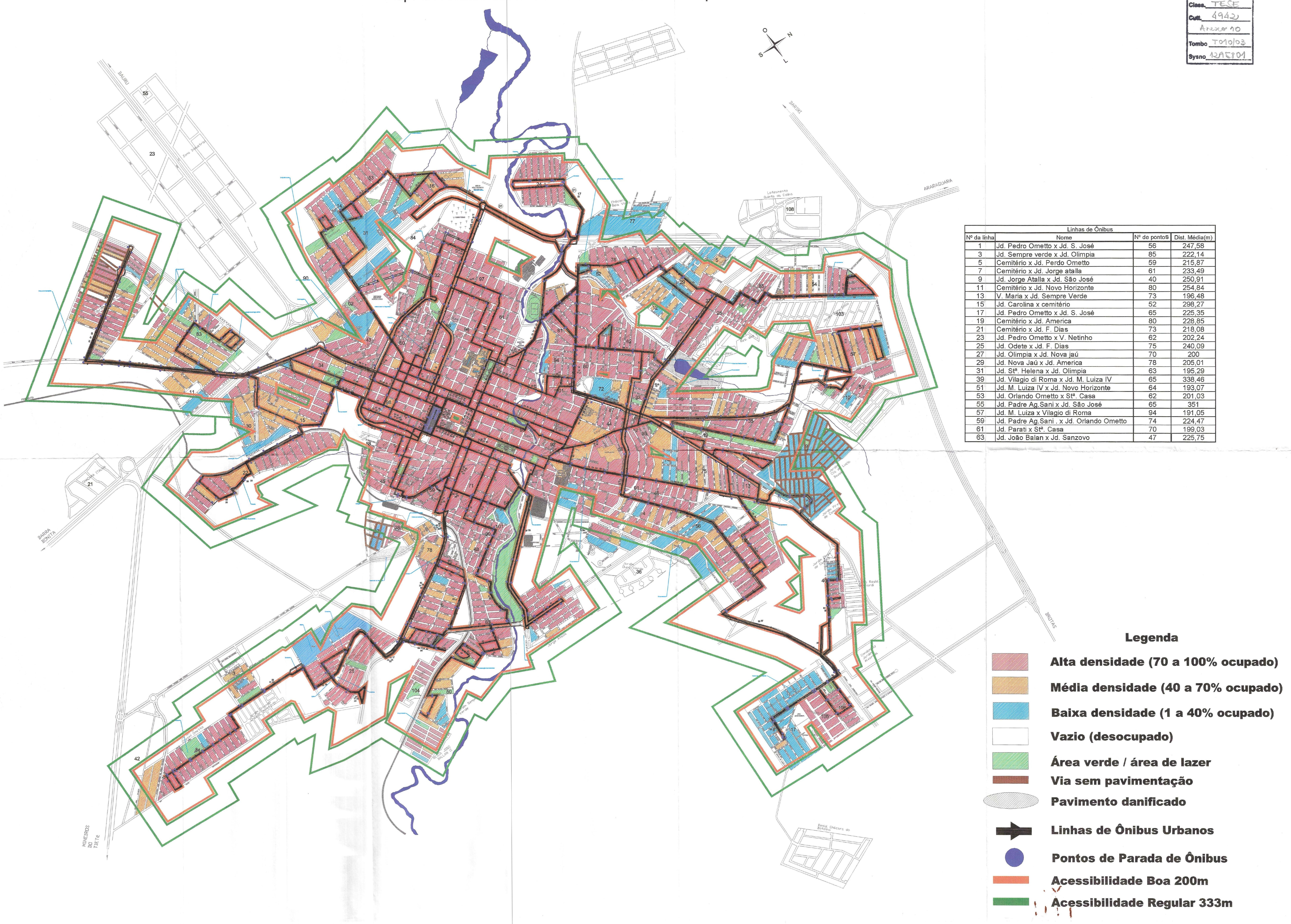




\section{REFERÊNCIAS BIBLIOGRÁFICAS}

Anuário 98/99 NTU. Associação Nacional das Empresas de Transportes Urbanos. http://www.ntu.org.br/publicacoes/anu 98 99/index.htm consultado em 11/02/2002

ANTP (1999) Transporte Humano, Cidades com Qualidade de Vida, 2a edição, GEIPOT, São Paulo, Brasil

Aragão, Brasileiro, Santos e Orrico $\mathrm{F}^{\circ}$ (2000) Sacudindo a poeira e construindo o novo ciclo de desenvolvimento do transporte público por ônibus. Pp 33 - 76 Transporte em tempos de reforma Santos, E. \& Aragão, J. L.G. E. Editora Brasília.

Aragón \& Leal (1999) Aspectos da implementação de um modelo de alocação para redes de transporte coletivo com congestionamento. Anais do XII CONGRESSO DA ASSOCIAÇÃO NACIONAL DE ENSINO E PESQUISA EM TRANSPORTES ANPET, pp 333 - 342.

Brasileiro (1996) Regulamentação do transporte por ônibus: a experiência francesa de gestão pública, Ônibus Urbano Regulamentação e Mercados, Aragão, Brasileiro, Santos e Orrico Fo, L.G. E. Editora Brasília

Bocanegra, C.R. (2002) Procedimentos para tornar mais efetivo o uso das redes neurais artificiais em planejamento de transportes. São Carlos. Dissertação ( Mestrado) Escola de Engenharia de São Carlos, Universidade de São Paulo.

Cochran,W (1977) Sampling Techniques. Wiley, New York.

Departamento Estadual de Trânsito - SP (2002) Dados disponíveis na Prefeitura Municipal de Jaú, através de convênio firmado com a Secretaria de Segurança Pública do Estado de São Paulo, que estabeleceu a Municipalização do Trânsito dessa cidade.

Ferraz, A. C. P. (1985) Considerações sobre a integração de linhas de ônibus como alternativa de racionalização da oferta nos corredores em cidades de porte médio. São Carlos.Tese ( Doutorado).Escola de Engenharia de São Carlos, Universidade de São Paulo. 
Ferraz, A. C. P. (1988) A qualidade do serviço de transporte coletivo em cidades médias sob a ótica dos usuários. II CONGRESSO DA ASSOCIAÇÃO NACIONAL DE ENSINO E PESQUISA EM TRANSPORTES - ANPET São Paulo. Anais v1 p. 111-126

Ferraz, A. C. P. (1998) Escritos sobre transporte, trânsito e urbanismo. Projeto Reenge. Editora São Francisco. São Carlos, SP.

Ferraz, A.C.P. \& Torres, I.G.E. (2001) Transporte Público Urbano, Rima Editora, São Carlos, Brasil.

IBGE (2000) IBGE Cidades. www.ibge.gov.br/cidadesat/xtras/perfil.php?codmun= $352530 \& \mathrm{r}=2$. consultado em 12/02/2002.

Kanafani, A. (1984) On the energy requirements of the public transport technologies. Transportation Planning and Technology. London, vol 9 , no 2, pp. 19-114.

Lima, I. M de O. ; Haddad, S.R. e Oliveira, M.A. (2001) Política nacional para o transporte urbano como instrumento de requalificação urbanaAnais em CD-ROM XIII Congresso da ANTP. Porto Alegre.

Mendes, J. (1999) Onde viver em Portugal: Uma análise da qualidade de vida nas capitais de distrito. Ordem dos Engenheiros- Regiào Centro, Coimbra, Portugal.

Raia Jr, A., Moreira, F. L. (2001) A qualidade do sistema de transporte coletivo por ônibus na cidade de são carlos sob a ótica dos usuários. Anais em CD-ROM XIII Congresso da ANTP. Porto Alegre.

Silva, A.N.R. \& Ferraz, A.C.P. (1994) Densidades urbanas e a eficiência do transporte público nas cidades médias brasileiras. VIII CONGRESSO PANAMERICANO DE INGENIERIA DE TRANSITO Y TRANSPORTES.México ,DF.p. 1004-1020

Silva, A. N.R. (1993) O custo do solo urbano ocioso e uma nova sistemática de tributação da propriedade. São Carlos.Tese(doutorado)- Escola de Engenharia de São Carlos, Universidade de São Paulo

Spinelli, L. B. \& Ferraz, A.C.P. (1999) Padrões de qualidade para o transporte público por ônibus em cidades de médio porte. Anais XII CONGRESSO DA ASSOCIAÇÃO NACIONAL DE ENSINO E PESQUISA EM TRANSPORTES - ANPET pp 277-287

Vuchic (2000) Transportation for livable cities. Center for Urban Policy Research. New Jersey, EUA. 
Waisman, J. (1983) Avaliação de desempenho de sistemas de ônibus, em cidades de porte médio em função de sua produtividade, eficiência operacional e qualidade dos serviços. São Carlos.Tese (Doutorado)- Escola de Engenharia de São Carlos, Universidade de São Paulo. 


\section{BIBLIOGRAFIA CONSULTADA}

AFFONSO, N. S.( 2001). Não transporte, 10 anos depois- Resultados do trabalho da comissão de circulação e urbanismo da ANTP. Revista dos transportes públicos-ANTP, no 91, p. 9-12.

ARIAS,P.A.; CAMPOS,V.B.G.; DIOGO,F.J.D'ALMEIDA.(2000).Transporte coletivo público urbano: seleção de alternativas. In: CONGRESSO DE PESQUISA E ENSINO EM TRANSPORTES,XIV,Gramado. p.65-68.

AGUIAR, E..M.(1985).Análise crítica dos indicadores de eficiência e eficácia propostos para avaliação de sistemas de transporte público urbano.158p.Dissertação (Mestrado)-Escola de Engenharia de São Carlos, Universidade de São Paulo

ANTP-(2001). O transporte na cidade do século 21. Associação Nacional de Transportes PúblicosANTP. http://www.antp.org.br/telas/transporte.htm

CAIAFFA, M. \& TYLER,N. (2000). Projeto de parada de ônibus: acessibilidade para passageiros.In: CONGRESSO PANAMERICANO DE ENGENHARIA DE TRÂNSITO E TRANSPORTE, XI.,Gramado.p.207-220.

COSTA,M.B.B; LINDAU,L.A.;SOUSA,F.B.B.;FOGLIATTO,F.(2001). Estudo compartativo entre empresas de ônibus utilizando AHP: o caso das empresas consorciadas de Porto Alegre.In: CONGRESSO DE PESQUISA E ENSINO EM TRANSPORTES,XV,Campinas. P.135-152.

DIAS, J. L. da S.(2001). Acessibilidade ambiental no transporte público por ônibus. Revista dos transportes públicos- ANTP, no 91, p.39-45.

DEPARTAMENTO DE TRANSPORTES METROPOLITANOS DO METRÔ DE SÀO PAULO(1989).Proposta de avaliação da qualidade do transporte público. Revista dos transportes públicos-ANTP.no 46 p.71-83.

FELEX,J.B. (1983). O usuário : um instrumento de avaliação.São Carlos.203pg. Tese(Doutorado)

Escola de Engenharia de São Carlos, Universidade de São Paulo 
FERRAZ,A.C.P.(1998). Qualidade no transporte público urbano.IN: Escritos sobre transporte, trânsito e urbanismo, p.118-124. Ed. São Francisco. Ribeirão Preto

FERRAZ, A. C. P.(1990). Sobre a eficácia e a eficiência do transporte público nas cidades médias. 157p. Tese( Livre-docência)- Escola de Engenharia de São Carlos, Universidade de São Carlos.

FERRAZ,A.C.P.(1988). A qualidade do serviço de transporte coletivo em cidades médias sob a ótica dos usuários In: Congresso de Ensino e Pesquisa em Transportes, 2.,São Paulo, ANPET.v.1,p.127-132

FERNANDEZ,R.; PEÑAILILLO, R. (2000).Un modelo microscópico de interacción entre paraderos de buses. In: CONGRESSO PANAMERICANO DE ENGENHARIA DE TRÂNSITO E TRANSPORTE,XI,Gramado. P.235-248.

GRAY,G. E.; HOEL,L.A.(1992).Public transportation.Prentice Hall.2 edição-New Jersey

GEIPOT (1983). Estudos de transportes urbanos para cidades de porte médio. Empresa Brasileira de Planejamento de Transportes. Brasília.

IBGE(2000).Censos demográficos e contagens populacionais do Estado de Sào Paulo. Fundação Instituto Brasileiro de Geografia e Estatística- IBGE. http://www.1.ibge.gov.br/ibge/estatistica/populacao/censohistorico/default.shtm

KAWAMOTO, E. (1984).Custo e nível de serviço no transporte público de passageiros por ônibus. São Carlos.100p. Dissertação ( Mestrado)- Escola de Engenharia de São Carlos, Universidade de São Paulo.

LIMA, O. H. S.de(2001). O transporte público e o jogo dos erros. Revista dos transportes públicos ANTP, no 91, p.7-8.

MORLOK, E. K. (1978).Introduction to transportation engineering and planning. New York, Mc Graw-Hill.

MOLINERO, A. R. M.;ARELLANO, L.I.S.(1997).Transporte público-Planeación,diseño,operación y administración.Universidad Autónoma del Estado de México.UAEM

ORRICO,R. D.; BRASILEIRO,A.;SANTOS,E.M.;ARAGÃO ,J.J.G.(1996).Ônibus Urbano: regulamentação e mercados. Editora LGE, Brasília. 
OLIVEIRA, C.C. de; CORREA,J.A.M.(2000). Uma perspectiva da evolução operacional e tecnológica do ônibus urbano no início do século XXI. In: CONGRESSO DE PESQUISA E ENSINO EM TRANSPORTES,XIV,Gramado.p.205- 212.

OLIVEIRA,C.A.; DUTRA,M.E.(1999). Apuração de reclamações de usuários de ônibus. In: CONGRESSO DE PESQUISA E ENSINO EM TRANSPORTES , XIII, São Carlos.p.39-46.

PDDT VIVO 2000/2020-Plano Diretor de Desenvolvimento de Transportes- Relatório Executivo.Dersa;Secretaria dos Transportes; Governo do Estado de São Paulo.

PROGRAMA DE QUALIDADE DO TRANSPORTE URBANO. -Uma estratégia de desenvolvimento de fornecedores. SPTRANS. São Paulo-(1997)

RIBEIRO NETO,A. A. A. (2001) . Contribuição à avaliação de transporte urbano por ônibus.São Carlos.81pg.Dissertação( Mestrado)- Escola de Engenharia de São Carlos, Universidade de São Paulo

RODRIGUES,M.(2001). Linhas e Trajetos-História do serviço de transporte coletivo de Santo André. $2^{a}$ edição. Secretaria de Serviços Municipais; Empresa Pública de Transportes e TrânsitoEPT; Prefeitura Municipal de Santo André

RIBEIRO,D.A.; JACQUES,M.A.P.(2000). Proposta para implantação de sistema de informação para usuários de transporte público.In: CONGRESSO DE PESQUISA E ENSINO EM TRANSPORTES,XIV,Gramado.p.165- 177.

SOUZA,H.H.H; CAMPOS,V.B.G ( 2000). Avaliação do desempenho de sistemas de transporte público urbano sob a ótica da eficácia..In: CONGRESSO DE PESQUISA E ENSINO EM TRANSPORTES,XIV, Gramado.p.121-128.

SILVA, A.N.R.;FERRAZ,A.C.P.(1994).Densidades urbanas e a eficiência do transporte público nas cidades médias brasileiras.In: VIII CONGRESSO PANAMERICANO DE INGENIERIA DE TRANSITO Y TRANSPORTES. México, DF.P.1004-1020.

SILVA, A. N. R.(1990) Densidades urbanas econômicas: a influência do transporte público.São Carlos.103 pg.Dissertação( Mestrado)- Escola de Engenharia de São Carlos, Universidade de São Paulo.

SEDU/PR(2001). Política nacional para o transporte urbano: documento para discussão.Secretaria Especial de Desenvolvimento Urbano, Presidência da República. Brasília./Relatório Técnico/ 
SANTOS,E.;ARAGÃO J.(2000). Transporte em tempos de reforma-Ensaios sobre a problemática. Editora LGE- Brasília

SANCHES,S.;VIOLATTO,R.R.(2000).Aceitabilidade de medidas de gerenciamento da demanda por transportes.In: CONGRESSO DE PESQUISA E ENSINO EM TRANSPORTES,XIV,Gramado.p.59-70.

SOUZA,M.A.F.;BODMER,M.(2000).Imagem e comunicação em transporte público : a realidade das empresas de transporte urbano por ônibus. In: CONGRESSO DE PESQUISA E ENSINO EM TRANSPORTES,XIV,Gramado.p.227-238.

SILVA,A.N.R;BRONDINO,N.C.M.;LIMA,R.S.(2000).O impacto de diferentes medidas de acessibilidade no valor do solo urbano.In: CONGRESSO DE PESQUISA E ENSINO EM TRANSPORTES, XIV,Gramado.p.349-359.

TEIXEIRA,A.P.; KIRIHATA,R.; SENNE,E.L.F.;BATISTA Jr,E.D.(2001) Sistemas de apoio à decisão para planejamento de transporte urbano de passageiros. In; CONGRESSO DE PESQUISA E ENSINO EM TRANSPORTES,XV,Campinas.p.57-64.

UNIVERSIDADE DE SÀO PAULO.Escola de Engenharia de São Carlos. Serviço de Biblioteca (1993).Diretrizes para elaboração de dissertações e teses na EESC-USP. São Carlos

VUCHIC, V.R.(1981) Urban public transportation: systems and technology. New Jersey, Prentice Hall.

VUKAN, V.R.(2000) Transportation for livable cities.Center for Urban Policy Research, New Jersey.

VIVIER,J.(2001).Tarifação dos transportes urbanos.Revista dos transportes públicos-ANTP, no 91,p.107-122.

VIEIRA,L.F.; SCHEIN,A.L.; DOMINGUEZ,E.M.;SENNA,L.A.S.(2000). Sistemas de informação ao usuário : avaliando as preferências dos usuários da bacia operacional sul-Porto Alegre. In; CONGRESSO DE PESQUISA E ENSINO EM TRANSPORTES,XIV,Gramado.p.215- 226.

WAISMAN, J. (1983). Avaliação de desempenho de sistemas de ônibus em cidades de porte médio, em função de sua produtividade, eficiência operacional e qualidade dos serviços.306 pg. Tese ( Doutorado) Escola de Engenharia de São Carlos- Universidade de São Paulo. 
WAISMAN,J.; MOHERDAUI,K. (2000). "Clube de transportes": a comunidade se organiza.In: CONGRESSO DE PESQUISA E ENSINO EM TRANSPORTES,XIV,Gramado.p.155-162.

YAMASHITA,Y.; COUTO, A. P. A.(2000). Análise de emissão de poluentes dos ônibus urbanos.In: CONGRESSO DE PESQUISA E ENSINO EM TRANSPORTES, XIV, Gramado. p.185191. 